UNIVERSIDADE DE SÃO PAULO

FACULDADE DE FILOSOFIA, LETRAS E CIÊNCIAS HUMANAS

DEPARTAMENTO DE HISTÓRIA

PROGRAMA DE PÓS-GRADUAÇÃO EM HISTÓRIA SOCIAL

NATALIA PEIXOTO BRAVO DE SOUZA

A militância em torno da glorificação de Euclides da Cunha: um projeto político-ideológico

São Paulo

2010 
UNIVERSIDADE DE SÃO PAULO

FACULDADE DE FILOSOFIA, LETRAS E CIÊNCIAS HUMANAS

DEPARTAMENTO DE HISTÓRIA

PROGRAMA DE PÓS-GRADUAÇÃO EM HISTÓRIA SOCIAL

\section{A militância em torno da glorificação de Euclides da Cunha: um projeto político-ideológico}

Dissertação apresentada ao Programa de Pós Graduação em História Social do Departamento de História da Faculdade de Filosofia, Letras e Ciências Humanas da Universidade de São Paulo, para a obtenção do título de Mestre em História.

Orientador: Profa. Dra. Maria Amélia Mascarenhas Dantes 


\section{AGRADECIMENTOS}

Este trabalho contou com a colaboração de familiares, amigos, professores e orientadores, sem os quais teria sido impossível terminar e persistir na pesquisa que lhe deu origem. Por isso, passo agora aos agradecimentos.

Agradeço, em primeiro lugar, aos meus pais, Luiz Paulo Bravo de Souza e Maria Lucia Peixoto Bravo de Souza, que me deram a oportunidade de ingressar no curso de História, na Pós-Graduação e de me dedicar apenas aos estudos, sem outras preocupações. Agradeço a meu avô, Acrysio Peixoto de Souza Filho, que sempre ouviu atentamente e com muito gosto as etapas da minha pesquisa, e me contou as experiências vividas por ele nas décadas de 30 e

40, que me ajudaram a compreender melhor este período- Agradeço também ao meu esposo, Alexander Matos Rocha, que esteve presente nas apresentações, me deu apoio e ajudou na formatação deste trabalho.

Agradeço a minha orientadora, Maria Amélia Dantes, que me acompanhou desde o início da pesquisa, fornecendo indicações de leitura importantes e idéias que contribuíram significativamente para o resultado alcançado com essa pesquisa, e à CAPES, pelo financiamento de minha pesquisa, que foi fundamental para o seu andamento.

Agradeço também à minha orientadora da iniciação científica, Heloísa Domingues, que me auxiliou e apoiou a minha idéia de, ainda na iniciação científica, iniciar as pesquisas sobre o referido Grêmio, deixando de lado aquela para a qual eu havia sido contratada.

Por fim, agradeço a Alberto Venâncio Filho, filho de Francisco Venâncio Filho, que me recebeu em seu escritório e, pacientemente, me forneceu importantes indicações de leitura e informações, sem as quais esse trabalho não teria sido possível. 


\section{RESUMO}

Este trabalho teve como principal objetivo discutir e analisar o papel de intelectuais cariocas das décadas de 30 e 40 do século XX na popularização de Euclides da Cunha e na construção de uma imagem que associa o escritor ao pensamento positivista. Para fundamentar a discussão e a análise, são analisados os conceitos de positivismo e evolucionismo, as trajetórias profissionais dos intelectuais citados, a militância dos mesmos no Grêmio Euclides da Cunha do Rio de Janeiro e a importância de suas atuações para a divulgação não só da obra de Euclides da Cunha, mas de uma interpretação específica sobre ela e sobre seu autor, contribuindo para cristalizar a noção de que Euclides da Cunha foi positivista. 


\section{ABSTRACT}

This work had as main objective to discuss and analyze the role of intellectuals in Rio at the decades of the 30th and 40th century in the popularization of Euclides da Cunha and the construction of an image that links the writer to positivist thinking. To support the discussion and analysis this work reviews the concepts of positivism and evolutionism, the career paths of intellectuals mentioned, the militancy of the same with Gremio Euclides da Cunha of Rio de Janeiro and the importance of their actions to disseminate not only the work of Euclides da Cunha, but a specific interpretation on it and on its author, helping to crystallize the notion that Euclides da Cunha was positivist. 


\section{SUMÁRIO}

INTRODUÇÃ

CAPÍTULO I: Matrizes teóricas do pensamento euclidiano ................................................. 13

1.1. Euclides da Cunha: positivista ou evolucionista? .......................................................... 13

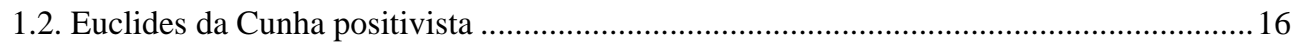

1.3. Positivismo e evolucionismo: semelhanças e diferenças ..............................................2 23

1.4. O pensamento euclidiano e suas matrizes. .............................................................. 29

CAPÍTULO II: A transformação de Euclides da Cunha em mito nacional ..............................37

2.1. Euclides da Cunha: de engenheiro e jornalista a grande escritor da nação ........................37

2.2. A tragicidade da morte de Euclides: contribuições para a criação do mito.......................42

2.3. O Grêmio Euclides da Cunha do Rio de Janeiro e o positivismo na construção da

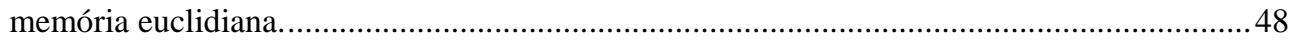

2.4. A valorização da literatura euclidiana como parte de um projeto de valorização da ciência69

2.5. A outra face do engajamento: a Associação Brasileira dos amigos de Auguste Comte.... 83

CAPÍTULO III: O crescimento da popularidade de Euclides da Cunha nas décadas de 30 e 40: contribuições da militância euclidiana

3.1. A criação e a consolidação do Grêmio Euclides da Cunha de São José do Rio Pardo.......89

3.1.1. O papel do Estado Novo no fortalecimento do Grêmio Euclides da Cunha de S. José do Rio Pardo

3.2. A contribuição dos euclidianos do Rio de Janeiro para a popularização de Euclides da Cunha 101

3.3. Euclides da Cunha ou Machado de Assis? Quem seria o maior escritor nacional? 116

3.4. A obsessão comemorativa e a luta contra o esquecimento: características dos grêmios Euclides da Cunha 128

CONCLUSÃO 133

FONTES 136 
BIBLIOGRAFIA 


\section{INTRODUÇÃO}

A idéia de estudar as razões que levaram um grupo de intelectuais brasileiros a liderar um movimento de glorificação e canonização de Euclides da Cunha, que contribuiu para a popularização de sua obra e para a interpretação do escritor como um intelectual positivista, surgiu a partir de uma pesquisa de iniciação científica.

Após ter sido chamada para uma bolsa PIBIC no Museu de Astronomia e Ciências Afins, fui encarregada de pesquisar a Revista Nacional de Educação e a Revista do Museu Nacional, responsáveis pela divulgação para um público mais amplo do trabalho realizado pelos pesquisadores do referido museu entre as décadas de 30 e 40. A idéia era pesquisar as relações entre os intelectuais do Museu Nacional, uma das grandes instituições de pesquisa em ciências naturais da época, e a antropologia, ciência que, ao longo do século XX, deixou progressivamente de lado suas teses raciais para adotar uma postura mais cultural. Pretendiase, portanto, a partir da leitura das revistas citadas, averiguar se, no Brasil, essa migração da antropologia de ciência racial para ciência cultural já tinha ocorrido nessa época, e quem eram os intelectuais envolvidos nessa produção. Sobre esse momento inicial de minha pesquisa, relacionado mais ao Museu Nacional e o espaço dedicado por ele à antropologia, afirma Regina Abreu ${ }^{1}$ :

De fato, as ciências naturais ali predominaram até pelo menos o final da década de 1930, quando foram fundadas as primeiras universidades do país. A antropologia, dedicada ao estudo do homem, era considerada um ramo das ciências naturais. Da administração de Ladislau Neto (1874) à de Batista Lacerda (1895-1915), essa situação não se alterou significativamente. A Ênfase era nos estudos de zoologia, botânica e geologia, havendo pouco espaço para a antropologia. A iniciativa de criação do setor de etnografia sertaneja e da Sala Euclides da Cunha revela mudança embrionária nos objetivos da instituição. Em primeiro lugar, era conferido peso maior à antropologia. Em segundo lugar, começava a ser valorizado o estudo da antropologia no Brasil, redimensionando a tendência do saber enciclopédico, até então vigente na instituição.

Com Roquette-Pinto, assinala Schwarcz, 'O Museu Nacional cumpriu um papel estranho à sua antiga atuação, tão marcada pelos modelos da biologia e da frenologia. Começava a aglutinar uma vanguarda intelectual,

\footnotetext{
${ }^{1}$ ABREU, Regina. O Enigma de Os Sertões. Rio de Janeiro, Funarte; 1988, p. 308.
} 
que ainda de forma frágil, se opunha fortemente ao racismo científico, moeda corrente em períodos imediatamente anteriores.

No entanto, o que mais chamou a minha atenção foi o espaço dedicado por boa parte desses intelectuais, nas duas revistas, a um mesmo tema: Euclides da Cunha.

A referência ao escritor era constante em quase todas as edições das duas revistas: Euclides era apresentado como geólogo, historiador, pai da antropogeografia, cientista, literato, entre outras identidades intelectuais. Dentre os colaboradores da revista, havia muito poucos que não tivessem se dedicado, ao menos em um artigo, a reverenciar e glorificar a figura de Euclides da Cunha. Tamanha identificação com Euclides da Cunha, não apenas de um intelectual, mas de vários pesquisadores dessa renomada instituição de pesquisa em ciências naturais, acabou me deixando, de certa forma, desconfiada. Eu me perguntava qual a relação de Euclides com as ciências naturais e os naturalistas, que é a forma como a ciência e os cientistas eram chamados naquele período, e quais os motivos que levaram esses intelectuais a, entre tantos escritores brasileiros, escolher exatamente Euclides da Cunha para reverenciar.

O andamento dessa nova pesquisa, iniciada por mim ainda na iniciação científica, demonstrou que o papel exercido por Roquette-Pinto na direção do Museu Nacional não somente mudou os rumos do museu, incluindo o estudo da antropologia entre os objetivos da instituição, como também foi determinante para a valorização da produção de e sobre Euclides da Cunha dentro do Museu Nacional. O andamento da pesquisa demonstrou, ainda, que a insistência no nome de Euclides da Cunha entre os colaboradores das revistas do Museu Nacional não era, de fato, apenas coincidência. Roquette-Pinto, o diretor da instituição durante o período estudado, pertenceu e foi uma das figuras mais ativas do movimento que mais influenciou a propagação e a popularização da obra de Euclides da Cunha entre as décadas de 30 e 40: o Grêmio Euclides da Cunha do Rio de Janeiro ${ }^{2}$. Tamanha dedicação, não só de Roquette-Pinto, mas de outros intelectuais à figura e à obra euclidianas também não foram obra do acaso: Euclides da Cunha simbolizava um modelo de literatura considerado ideal por aquele grupo de intelectuais, ligados às ciências naturais: o da literatura científica.

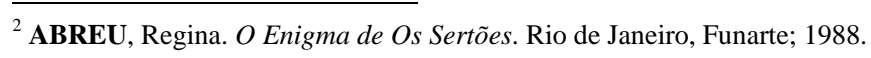


Os desdobramentos dessa pesquisa, as hipóteses, investigações e resultados alcançados após os anos de estudo no curso de mestrado em História Social estão relatados no trabalho que se segue.

No primeiro capítulo, tratarei de uma questão mais pontual: definir e analisar quais as matrizes ideológicas e científicas que nortearam o pensamento e, mais do que isso, a produção bibliográfica de Euclides da Cunha. Neste capítulo, tenta-se relativizar o que é visto pela historiografia e pela crítica em geral como uma adesão incondicional de Euclides da Cunha ao positivismo. A partir da definição dos dois conceitos - positivismo e evolucionismo - de suas semelhanças e diferenças e da análise do livro mais importante de Euclides da Cunha, Os Sertões, pretende-se questionar o fato de Euclides estar tão associado ao positivismo, apesar de sua produção bibliográfica ser tão marcada pelo evolucionismo. A partir daí, algumas hipóteses são lançadas a respeito desses realces e esquecimentos que contribuíram para a construção de uma memória que, além de transformar Euclides em um dos maiores escritores nacionais, transformou-o também em unicamente positivista. No entanto, não é intenção deste capítulo, e deste trabalho, negar a influência que Euclides teria sofrido da filosofia positivista. Pretende-se apenas mostrar que essa foi apenas uma de suas influências em termos de teoria científica, talvez não a mais relevante. A marca do evolucionismo nos escritos de Euclides parece mais evidente, e, no entanto, quase não é citada pelos estudiosos de sua obra que publicam nas revistas analisadas. Por esse motivo, este primeiro capítulo é dedicado a definir alguns conceitos e lançar algumas hipóteses a respeito dessa construção histórica em torno da figura de Euclides da Cunha, construção esta que acarretou em alguns esquecimentos.

No segundo capítulo, é abordada mais detalhadamente a criação do Grêmio euclidiano do Rio de Janeiro, onde se reuniam euclidianos e positivistas como Roquette-Pinto e Venâncio Filho. Nessa parte, aparece a idéia de que a forma como Euclides foi homenageado no Grêmio Euclides da Cunha, com estátuas, oração, romarias, dia e lugar santos, entre outras coisas, é muito similar à forma como eram tratados os Vultos da Humanidade cultuados na igreja positivista. Embora seja sabido que apenas determinados homens e mulheres, selecionados como grandes vultos fossem objeto de culto no apostolado positivista, a filiação ideológica de alguns dos dirigentes do Grêmio ao positivismo pode ter contribuído para tornar o ritual de veneração a Euclides da Cunha muito similar ao da igreja positivista. Essa semelhança é 
notada não apenas no caso do grêmio do Rio de Janeiro, mas também no de São José do Rio Pardo. A troca de informações intensa entre os dois grêmios pode ter contribuído para que a agremiação paulista adotasse formas de veneração parecidas com as do grêmio carioca também em suas celebrações. O capítulo trata, ainda, da forma como Os Sertões foram recebidos pela crítica desde a sua primeira publicação, e de como a morte trágica de que foi vítima o escritor também pode ter ajudado na transformação de Euclides em grande herói nacional. O capítulo trata, ainda, da criação, na década de 40, de uma associação com o objetivo de estudar e de, mais uma vez, não deixar cair em esquecimento a memória de Auguste Comte. Dessa associação, liderada por Mario Carneiro, fizeram parte todos os euclidianos estudados, tendo Venâncio Filho ocupado um lugar de destaque na mesma. Ainda que Comte não tenha sido venerado como foi Euclides da Cunha na citada instituição, a criação e a participação dos euclidianos estudados em uma associação em homenagem a Comte institucionalizou a ligação entre os mesmos e a filosofia de Comte, ligação essa que já era perceptível anteriormente.

Finalmente, tenta-se mostrar, neste capítulo, como a imagem de Euclides da Cunha ressaltada pelos intelectuais positivistas era predominantemente a de um homem de ciência, além de escritor, o que, na visão desses mesmos intelectuais, era visto como uma grande qualidade. Essa pode ter sido, portanto, a principal razão de sua glorificação por parte dos positivistas, ainda que eles próprios reconhecessem inúmeras outras qualidades em Euclides e que tenha havido, dentro do Grêmio Euclides da Cunha do Rio de Janeiro e também no do estado de São Paulo, muitos admiradores de Euclides que não eram positivistas e reverenciavam o escritor por inúmeros outros motivos.

No terceiro capítulo, é analisada a criação do Grêmio Euclides da Cunha de São José do Rio Pardo e a mudança, ao longo dos anos, na forma pela qual os habitantes da cidade homenagearam o escritor. É discutida, ainda, a hipótese de Regina Abreu, de que o crescimento do Grêmio paulista entre as décadas de 30 e 40 de deveu ao apoio do governo federal, além do estadual, às iniciativas do Grêmio em homenagem ao escritor.

Neste capítulo, também é abordado de forma mais específica, como a militância dos intelectuais que são o objeto deste estudo, Edgar Sussekind de Mendonça, Venâncio Filho e 
Roquette-Pinto, contribuiu de maneira fundamental para uma maior divulgação da obra e do Grêmio citado. É tratada também, ainda no terceiro capítulo, outra questão importante para os euclidianos: a transformação de Euclides da Cunha em maior escritor nacional e em mais brasileiro dos escritores nacionais. O capítulo também menciona o que parece ter sido uma discussão entre alguns acadêmicos da época acerca de quem seria o maior escritor nacional: Euclides da Cunha ou Machado de Assis?

Por fim, este capítulo pretende demonstrar que o trabalho de esquecimento a respeito do vínculo entre Euclides da Cunha e o evolucionismo também recebeu uma contribuição dos já citados intelectuais positivistas. Tanto Venâncio Filho como Roquette-Pinto, apesar de ressaltarem constantemente a postura científica de Euclides da Cunha, pouco se pronunciaram, ou o fizeram em tom de justificativa, a respeito de sua adesão ao evolucionismo, ajudando a construir, assim, uma imagem de Euclides da Cunha positivista, similar à deles próprios. 


\section{CAPÍTULO I: Matrizes teóricas do pensamento euclidiano}

\subsection{Euclides da Cunha: positivista ou evolucionista?}

A pergunta feita acima já foi objeto de um artigo de minha autoria. ${ }^{3}$ Acredito que seja importante incluir o assunto novamente em minha dissertação de mestrado, pois é exatamente a problematização dessa identidade, quase automática, entre Euclides da Cunha e o positivismo, que é feita pela historiografia, que me permite desenvolver o meu argumento principal, de que os positivistas euclidianos da década de 30, dirigentes do Grêmio Euclides da Cunha do Rio de Janeiro, participaram ativamente da construção dessa memória. Desse modo, faz-se necessário discutir as matrizes teóricas da produção bibliográfica de Euclides da Cunha, e suas possíveis aproximações e distanciamentos com o positivismo e o evolucionismo.

Inicialmente, é necessário definir alguns conceitos, que serão importantes para responder à pergunta acima. Afinal, Euclides da Cunha foi positivista ou evolucionista? Como foi criada essa memória, que associa de forma tão automática e intrínseca a figura de Euclides da Cunha ao pensamento positivista? Mais que isso, porque o escritor aparece sempre como um símbolo da identidade nacional, como bem o demonstra a sua inclusão na série Identidade Brasileira, editada pela Editora Contraponto ${ }^{4}$. Nesta série, o escritor aparece ao lado de "heróis nacionais” como Santos Dumont e o Barão do Rio Branco, cada um com sua respectiva biografia. Certamente, a inclusão de Euclides da Cunha entre os integrantes de uma série com esse nome não é acidental. Como veremos, uma das hipóteses deste trabalho é a de que a memória criada a respeito do escritor está intimamente relacionada à idéia de que Euclides foi, além de positivista, um dos grandes responsáveis pela incorporação do sertanejo ao panorama nacional. Daí a sua ligação com a construção de uma identidade nacional que incluiu também o sertanejo.

\footnotetext{
${ }^{3}$ SOUZA, Natália Peixoto Bravo e GALVÃo, Gastão. O estigma de uma obra: Euclides da Cunha e suas reapropriações sob o ponto de vista do positivismo e do evolucionismo. In: Revista da Sociedade Brasileira de História da Ciência, 2007, Rio de Janeiro, p. 173-184.
} 
Não é objetivo deste trabalho fornecer respostas acabadas sobre tais questões, que possam, finalmente, estabelecer a verdade sobre a identidade intelectual do escritor. A intenção é a de, apenas, indicar alguns possíveis caminhos e compartilhar algumas das hipóteses que têm sido consideradas ao longo de toda a pesquisa. O trabalho não pretende, ainda, aprisionar Euclides da Cunha em apenas uma filiação ideológica e intelectual, e negar com isso sua possível identificação com outras correntes de pensamento da época, entre elas o próprio positivismo. A ligação e a admiração do escritor por positivistas históricos como Benjamin Constant já foi muitas vezes abordada pela historiografia recente, e negar esse fato seria uma imprudência. O que este trabalho tenciona é entender porque, sendo a produção bibliográfica de Euclides tão marcada pelas teorias evolucionistas de sua época, seu nome ficou associado, sobretudo, ao positivismo, que não foi a única doutrina científica e filosófica a ter influência em sua trajetória intelectual. Para tanto, é necessário investigar qual a contribuição dos intelectuais positivistas e euclidianos da década de 30 na construção dessa memória.

Outra questão importante que deve ser ressaltada diz respeito às diferenças conceituais e metodológicas entre o positivismo e o evolucionismo que, se negligenciadas, podem causar algumas confusões, como a de achar que as teorias raciais utilizadas por Euclides para diagnosticar o 'atraso' do sertanejo são teorias positivistas, quando na verdade elas são evolucionistas. Essa é uma interpretação que aparece, como será comentado adiante, no trabalho de Mônica Velloso ${ }^{5}$, que denomina a postura da geração de 1870, da qual faziam parte Silvio Romero e Euclides da Cunha, de positivista. Dessa perspectiva, portanto, seriam positivistas as teorias de superioridade e inferioridade raciais, do autoctonismo das raças americanas e da adaptação ao meio, que aparecem com freqüência no principal trabalho de Euclides $^{6}$ e também no de Romero que, aliás, é um dos críticos literários responsáveis pela boa recepção do livro de Euclides nos meios jornalísticos da época ${ }^{7}$. E relacionar positivismo e teorias raciais, além de um equívoco conceitual, acarreta um anacronismo já que, quando Darwin publicou o seu A Origem das Espécies ${ }^{8}$,em 1859, Comte já havia falecido há dois anos. Teria sido, portanto, impossível para o autor ler e se apropriar da obra que serviria de

\footnotetext{
${ }^{4}$ LIMA, Luiz Costa. Euclides da Cunha: Contrastes e confrontos do Brasil. Rio de Janeiro: Contraponto/ NUSEG, 2000.

${ }^{5}$ VELLOSO, Mônica Pimenta. A literatura como espelho da nação. Estudos Históricos, Rio de Janeiro, vol.1, n.2, 1988.

${ }^{6}$ O Homem. In: DA CUNHA, Euclides. Os Sertões. São Paulo, Ed. Ática, 1988, p.65-182.

${ }^{7}$ ABREU, Regina. O enigma de Os Sertões. Rio de Janeiro: Rocco, 1988, p. 245.
} 
grande inspiração para o pensamento spenceriano, elaborado anos mais tarde. Além disso, não há na obra de Auguste Comte qualquer hierarquização de raças que pudesse ter sido usada por Euclides como referência. Comte não se pronunciou a respeito da questão racial, e essa é uma das grandes diferenças entre as duas teorias, positivismo e evolucionismo. Semelhanças as duas teorias também têm, como, aliás, boa parte das teorias sociais de cunho científico da mesma época possuem. Essas semelhanças também serão abordadas no trabalho.

No entanto, o principal objetivo desse primeiro capítulo, é o de apontar as contradições existentes entre essas duas correntes, que dificultam que um intelectual opte por seguir as duas linhagens teóricas ao mesmo tempo. Desse modo, e tal como afirma Miguel Reale em livro intitulado Face Oculta de Euclides da Cunha ${ }^{9}$, Euclides possivelmente__passou sua juventude encantado pelo positivismo Comtiano, do qual mais tarde se afastou para abraçar as idéias do evolucionismo. Mesmo tendo se afastado do positivismo, o escritor não rompeu completamente com essa teoria. No entanto, essa corrente científica perdeu progressivamente importância como matriz intelectual do escritor, que a julgava insuficiente e incapaz de diagnosticar os reais problemas da sociedade ${ }^{10}$. Como evidências da utilização por Euclides da Cunha de muitos preceitos evolucionistas em seus escritos, temos, além dos inúmeros trechos de Os Sertões que serão discutidos adiante, várias afirmações do escritor em suas crônicas, algumas elogiando, outras criticando Herbert Spencer, mas sempre discutindo e utilizando suas principais idéias para diagnosticar os reais problemas da sociedade brasileira. Entre esses trechos, podemos citar $^{11}{ }_{-}^{12} \underline{13}$ :

Acabo de ler uma página iluminada de Spencer, em que o eminente evolucionista- como bom filósofo crente na perfectibilidade humanavaticina uma idade de ouro, durante a qual por um mais dilatado domínio das forças naturais se satisfaçam mais facilmente as necessidades imperiosas da existência e menos assoberbada de trabalho, tenha afinal a humanidade tempo de aformosear a vida, pela contemplação do belo na natureza e na arte. O ilustre mestre deixou-se arrebatar demais pelas tendências profundamente humanas de seu grande espírito.

\footnotetext{
${ }^{8}$ DARWIN, Charles. A Origem das Espécies. São Paulo, Hemus, 1981.

${ }_{9}^{9}$ REALE, Miguel. Face Oculta de Euclides da Cunha. Rio de Janeiro, Topbooks, 1993.

${ }^{10}$ CUNHA, Euclides. Obra Completa. Rio de Janeiro. Nova Aguillar, 1966, p. 656.

11 Artigo de Euclides da Cunha de 19 de março de 1892. Disponível em: http://pt.wikisource.org/wiki/Artigo_de_Euclides_da_Cunha_de_19_de_mar\%C3\%A7o_de_1892. Acesso em janeiro 2010 .

${ }^{13}$ Idem Ibidem
} 
O Stuggle foi life, a fórmula majestosa da nossa elevação constante, terá a mesma feição autoritária e fatal, embora atuando entre os deslumbramentos da mais alta civilização.

Em outro artigo, intitulado Nativismo provisório, Euclides da Cunha não tece os mesmos elogios a Spencer, mas continua a utilizar o seu referencial teórico para tecer suas análises ${ }^{14}$ :

O Brasil não é como os Estados Unidos ou a Austrália, onde o inglês, o alemão ou o francês alteram e cambiam as qualidades nativas ou as refundem e refinam, originando um tipo novo e mais elevado do que os elementos formadores. Está numa situação provisória de fraqueza, na franca instabilidade de uma combinação incompleta de efeitos ainda imprevistos, em que a variedade dos sangues, que se caldeiam, implica o dispersivo das tendências díspares, que se entrelaçam. (...)

As últimas páginas de $H$. Spencer são um diluente do esplêndido rigorismo das suas mais sólidas teorias. O filósofo, que se abalançou traduzir o desdobramento evolutivo das sociedades numa fórmula tão concisa $e$ fulgurante quanto a fórmula analítica em que Lagrange fundiu toda a mecânica racional- acabou num lastimável desalento. A seu parecer, a civilização desfecha na barbaria.

Depois de presidir ao triunfo das ciências e de caracterizar os seus reflexos criadores nas maiores maravilhas das indústrias- assombrou-o à ultima hora, salteando-o de espanto, o sombrio alvorecer crepuscular do novo século. E contemplando em toda a parte, de par com a desorientação científica, um extravagante renascimento da atividade militar e um imperialismo que denuncia a tendência das nacionalidades robustas a firmarem a hegemonia política- rematou uma vida que toda ela foi um hino ao progresso, confessando que assistia à decadência universal.

\section{Exagerou...}

Mas há um faro incontestável: o pendor atual e irresistível das raças fortes para o domínio, não pela espada, efêmeras vitórias ou conquistas territoriais- mas pela infiltração poderosa do seu gênio e da sua atividade.

(...) Reconhece-se, afinal que o nosso código orgânico não enfeixa as condições naturais do progresso; e que andamos há quinze anos no convívio das nações com a aparência pouco apresentável de quem, meão na altura, se revestiu desastradamente com as vestes de um colosso.

\subsection{Euclides da Cunha positivista}

\footnotetext{
${ }^{14}$ Idem Ibidem.
} 
A afirmação de que a figura de Euclides da Cunha está intrinsecamente ligada ao positivismo não é apenas uma intuição: essa ligação está presente na obra de historiadores renomados ${ }^{15}$, e mesmo no sítio da Igreja positivista do Rio de Janeiro ${ }^{16}$, o escritor aparece como um dos seguidores da doutrina. Um dos numerosos exemplos dessa ligação feita pelos acadêmicos entre Euclides da Cunha e o positivismo aparece em um texto do historiador Nicolau Sevcenko, intitulado “O prelúdio republicano, astúcias da ordem e ilusões do progresso.” 17

No texto, Sevcenko, ao tratar da guerra de Canudos, da qual Euclides participou como correspondente, diz que "Dessa última expedição participou como correspondente de guerra do jornal O Estado de São Paulo o jovem escritor positivista Euclides da Cunha, formado engenheiro na escola militar da praia vermelha."

Também na obra da historiadora Mônica Velloso essa ligação entre Euclides e o positivismo aparece. Em texto intitulado “A literatura como espelho da nação”, a pesquisadora, ao estudar a chamada Geração de 1870, atribui à mesma uma postura positivista, com base no gosto por uma literatura documental, na utilização de parâmetros científicos, na idéia de que o meio explica o homem, entre outras características. Nas palavras da própria autora ${ }^{18}$ :

Essa concepção de literatura, vista como apêndice ou epifenômeno da realidade, é de matriz positivista. Encarada como discurso menor ou discurso de segunda grandeza, a literatura só passa a ser respeitada quando escorada pelos parâmetros cientificistas.

Conforme Velloso, a literatura vista como epifenômeno da realidade é de matriz positivista, sendo quaisquer manifestações literárias que não tivessem um caráter científico-positivista encaradas como um discurso de menor importância. Essa postura, identificada pela autora como positivista, não é, entretanto, exclusividade do positivismo. Autores da geração de 1870 como Silvio Romero, Tobias Barreto e o próprio Euclides da Cunha não se cognominavam positivistas. Silvio Romero, inclusive, chegou a escrever um livro, intitulado "Doutrina

\footnotetext{
${ }^{15}$ ORTIZ, Renato. Cultura brasileira e identidade nacional. 3a ed. - São Paulo: Brasiliense.

VELLOSO, Monica. O Modernismo e a Questão Nacional, in: FERREIRA, Jorge e DELGADO, Lucília de Almeida Neves (org.). O Brasil Republicano. Rio de Janeiro, Civilização Brasileira, 2003.

${ }^{16}$ www.igrejapositivistadobrasil.org.br. Acesso em Agosto/ 2009.

17 SEVCENKO, Nicolau O prelúdio republicano, astucias da ordem e ilusões do progresso in: NOVAIS, Fernando A. História da vida privada no Brasil. São Paulo: Companhia das Letras, 1997- 4 v., p. 18.

${ }^{18}$ VELLOSO, Mônica Pimenta. A literatura como espelho da nação. Estudos Históricos, Rio de Janeiro, vol.1, n.2, 1988, p.240.
} 
contra Doutrina” ${ }^{19}$, praticamente todo dedicado a desmerecer o positivismo comtiano e a enaltecer o evolucionismo. Como o próprio Silvio Romero deixa claro, o objetivo do livro era exatamente conseguir mais adeptos do evolucionismo entre a juventude, que naquele período parecia se encantar mais com o positivismo. Além do citado livro, houve outros momentos em que Romero criticou explicitamente o positivismo, que chamava de um dogmatismo de fanáticos. Nem a teoria positivista de evolução social, geralmente aceita mesmo por aqueles que criticavam o dogmatismo de Comte, ficou a salvo das críticas de Romero. Em texto intitulado "A classificação dos fenômenos em sociologia" ${ }^{20}$, Romero critica a idéia de que a ciência substituiria a religião, presente em Comte. Segundo o autor, religião e ciência coexistiram em diferentes momentos da evolução histórica e por isso não seria correto afirmar que uma seria a substituta da outra. Nas palavras de Silvio Romero:

Ainda agora vemos, por exemplo, os positivistas juntarem num só conceito o desenvolvimento da ciência com religião, subordinando tudo aos dogmas desta última. Ainda hoje os naturalistas de velho estilo acreditam que a ciência está destinada a substituir a religião. Ainda em nosso tempo muita gente supõe que a arte vai morrer, deixando o lugar à ciência ou à indústria. Estas e outras coisas análogas correm por aí afoitamente.

E mais adiante:

A falsa compreensão dessa característica fundamental das criações humanas tem sido a origem de muitas teorias e doutrinas extravagantes. Por desconhecê-la é que tem havido quem suponha que a arte pode morrer, sendo substituída pela religião, segundo uns, ou pela ciência, segundo outros; por esquecê-la é que tem havido quem proclame a subordinação da moral, da arte, da ciência, à religião, como fazem os positivistas; por olvidá-la é que tem havido quem nos fale de uma arte utilitária. Como se uma ou outra pudessem e devessem acabar com esses abusos, oriundos do desconhecimento da verdadeira índole dos fenômenos culturais.

A trajetória de Silvio Romero parece ter sido bastante similar ao que supomos nesse capítulo ter sido o de Euclides da Cunha, qual seja, o de um intelectual que, após um breve período de adesão ao positivismo, opta por se converter ao evolucionismo spenceriano. Entretanto, essa conversão de Euclides ao evolucionismo spenceriano não parece ter sido uma

\footnotetext{
${ }^{19}$ ROMERO, Silvio. Doutrina contra Doutrina. O evolucionismo e o positivismo na república do Brasil. Rio de Janeiro. Editor J.B Nunes.1894.
}

${ }^{20}$ ROMERO, Silvio: ensaios de sociologia e literatura. Rio de Janeiro: H. Garnier, 1901, p.50. 
conversão total, apaixonada e militante, como no caso de Romero. Euclides continuou a estudar e a informar seus trabalhos e estudos de uma série de outros trabalhos e teorias científicas não spencerianas, mas geralmente também evolucionistas

Ainda sobre Silvio Romero, também Antonio Candido ${ }^{21}$ afirma que ele passou, em sua formação intelectual, por uma primeira fase de adesão ao positivismo comtiano, do qual mais tarde teria se afastado para abraçar as idéias do evolucionismo spenceriano, o que se confirmaria nas afirmações do próprio Silvio Romero ${ }^{22}$ :

Em 1868(...) no Recife, já eu e meus amigos líamos Comte, Littré, Buckle, Taine, Max Muller, Renan, Vacherot. (...)

Comte só foi largado por amor a Spencer, a Darwin, a Haeckel, a Büchner, a Vogt, a Moleschott, a Huxley.

Um desses amigos aos quais se refere Silvio Romero certamente foi Tobias Barreto, formado intelectualmente no mesmo ambiente de propagação das teorias científicas que o autor. Ambos faziam parte do chamado grupo do Recife. Ainda sobre a formação intelectual de Silvio Romero, escreve Antonio Candido ${ }^{23}$ :

Silvio teve uma admiração sem limites pelas correntes de seu tempo e, até o fim da vida, não perdeu mais certo ar de novo-rico da cultura, usando e abusando de termos técnicos, inventando designações, apelando a cada instante para os seus mentores. Os principais deles foram Buckle, Taine, Haeckel e Spencer. Embora tenha sempre conservado a impregnação de alguns ensinamentos do positivismo Comtiano, foram esses autores (acessiveis e de fácil leitura) que lhe forneceram os fundamentos da intuição - para usar seu o termo predileto.

E mais adiante:

Logo, ao contrário do que pensava no ano anterior, o positivismo não pode dar a nova fórmula política. Já então se desligara dele, e há nesse ensaio um trecho onde o censura por desconhecer a psicologia, erro que o Darwinismo - "ao lado de outras idéias vai corrigindo"- o que denota passagem ao evolucionismo. Por outras palavras, adota a crítica spenceriana à classificação das ciências de Comte.

\footnotetext{
${ }^{21}$ CANDIDO, Antonio. O método crítico de Silvio Romero. São Paulo: Ed. da Universidade de São Paulo, 1988, p. 68.

${ }_{22}$ Idem Ibidem.

${ }^{23}$ Idem Ibidem, p. 30.
} 
Desse modo, e assim como outros intelectuais dessa época, como Araripe Junior, Capistrano de Abreu e o próprio Euclides da Cunha, Silvio Romero, apesar de ter travado contato com a teoria comtiana, abandonou-a mais tarde para seguir os ensinamentos dos evolucionistas. O próprio fato de Silvio Romero ter afirmado que largou o positivismo em benefício das teorias evolucionistas, pode ser lido como um possível reconhecimento, da parte de Romero, da sua dificuldade de aderir às duas doutrinas ao mesmo tempo, já que as duas possuíam contradições flagrantes.

Para Silvio Romero, desmerecer o positivismo tinha se tornado uma espécie de militância política e ideológica. Nenhuma parte do positivismo ficou a salvo de suas críticas. Algumas afirmações do próprio autor deixam bem claras as suas intenções ${ }^{24}$ :

O positivismo é uma coisa perigosa e deve ser combatido com seriedade. Desde que uma doutrina, qualquer que ela seja, tornou-se o pão espiritual de algumas centenas de homens, essa doutrina distribui alento e entusiasmo, aviventa as forças d'alma, afirma-se como um incentivo em nome do futuro. $E$ coisas assim tão graves só podem ser tratadas com seriedade $e$ compostura. Podemos tomar com elas a nossa parte de divertimento $e$ gracejo, porque tudo neste mundo tem o seu momento cômico; mas este expediente deve ser passageiro e relegado para o segundo plano.

O positivismo no mundo e, nomeadamente no Brasil, deve ser combatido larga, tenaz, e sistematicamente, ponto por ponto, doutrina por doutrina.

Afinal o positivismo reduziu-se subjetiva, que se opõe radicalmente à portentosa síntese objetiva do evolucionismo naturalista.

As duas intuições estão em luta, e antes de passar adiante, será conveniente mostrá-las em confronto, destacar uma em face da outra.

Leiam, estudem os nossos homens de talento as obras de Darwin, de Haeckel, de Wundt, de Spencer, de Bain, e achar-se-ão abroquelados contra a devastação do inquisitorialismo comtesco-clotildista, e ahar-se-ão com forças para evitar a atropia espiritual produzida por essa filosofia modorrenta, paralisadora, mansenilha cruel do pensamento e do coração, que amofina e cresta quem quer que se lhe deixa apanhar nas enrediças teias.

Entregamos à nação neste livro de fé, de patriotismo e de esperança.

\footnotetext{
${ }^{24}$ ROMERO, Silvio. Doutrina contra Doutrina. O evolucionismo e o positivismo na república do Brasil. Rio de Janeiro. Editor J.B Nunes.1894, p. 237.
} 
Todas as afirmações acima demonstram que Silvio Romero pretendia, ao escrever o livro “Doutrina contra Doutrina”, produzir um manifesto anti-positivista e recrutar os jovens estudantes ao evolucionismo, e não ao positivismo. Toda essa preocupação de Silvio Romero está relacionada à popularidade dos ideais positivistas, sobretudo entre os jovens recém egressos da Escola Militar da Praia Vermelha. A popularidade do positivismo era vista por Romero como um mal a ser combatido. A crônica de João do Rio, que era filho de um professor positivista, atesta a popularidade do credo na virada do século XIX para o XX no Rio de Janeiro. Em crônica intitulada “A Igreja Positivista” 25, o autor escreve:

- É grande o número de positivistas?

- No Brasil os ortodoxos devem ser uns 700. Os simpáticos não se podem mais contar. As gerações que saem da nossa escola militar são quase que compostas de simpáticos.

Hugo Lovisolo, em texto intitulado “O positivismo na Argentina e no Brasil” ${ }^{26}$, também afirma que:

\begin{abstract}
A dominância do comtismo parece haver sido profunda. Um testemunho indireto é proporcionado por Anatole France. Em 1908, em conferência pronunciada na Academia Brasileira de Letras, no Rio de Janeiro, Anatole constrói seu discurso para um público definido como positivista comtiano. Por isso, ataca as contradições e as práticas de Lafitte, mostrando seu oportunismo político e suas vinculações com a reação conservadora, autoritária e católica na França. Anatole France não tem dúvidas de que no Brasil, ou pelo menos na sua capital política, domina o positivismo comtiano. Testemunhos da época e revisões históricas posteriores batem na mesma tecla.
\end{abstract}

Os testemunhos acima nos oferecem mais uma evidência das razões da preocupação excessiva de Silvio Romero com a difusão do positivismo entre os jovens da capital federal, entre fins do século XIX e o início do século XX. Apesar de considerar o evolucionismo superior ao positivismo, Romero reconhecia o sucesso que a teoria de Comte fazia entre a juventude de sua época, e por isso enveredou por um caminho de militância pró evolucionismo e contra o positivismo.

\footnotetext{
${ }^{25}$ DO RIO, João: A Igreja Positivista. Disponível em: http://pt.wikisource.org/wiki/A_Igreja_Positivista. Acesso em Agosto/2009.

${ }^{26}$ LOVISOLO, Hugo. O Positivismo na Argentina e no Brasil. In: Revista Brasileira de Ciências Sociais. Disponível em: http://www.anpocs.org.br/portal/content/view/123/54/. Acesso em Agosto/2009.
} 
Portanto, de acordo com Antonio Candido ${ }^{27}$, Romero abandonou suas convicções de juventude e abraçou as teorias evolucionistas da época. Este também parece ter sido o caso de Euclides da Cunha, embora o escritor, ao contrário de Romero, não tenha se envolvido em polêmicas, discussões e defesas apaixonadas do evolucionismo. Euclides também não repudiava o positivismo da forma que fazia Silvio Romero. De acordo com Miguel Reale, em livro intitulado "Face Oculta de Euclides da Cunha”, Euclides ainda conservava, do seu tempo de maior simpatia ao positivismo, a crença na lei positivista dos três estados, embora já preferisse Herbert Spencer ao pensamento comtiano. Nas palavras de Reale: ${ }^{28}$ :

Em páginas de admirável lucidez, contrastantes com os chavões positivistas então correntes, Euclides contesta veementemente o filósofo português quando afirma que o Brasil fora dominado pelo positivismo 'inteiramente e de pancada', absorvendo 'tudo, liturgia com o resto'. Conforme se lê de páginas 399 a 412 do vol-I, de O.C., Euclides lembra que 'apenas uma minoria diminutíssima aceitou todas as conclusões do pontífice. A maioria permaneceu autônoma'. Frisa ser incontestável que 'em nossas indagações científicas preponderam, exclusivos em toda linha, o monismo germânico e o evolucionismo inglês', (meus os grifos), sem esquecimento do que de válido havia em Comte em termos de teoria científica. Como se vê, o autor de Contrastes e confrontos não incidiu no erro de confundir o positivismo com a filosofia científico-positiva, esta sim prevalecente não só no Brasil, mas no mundo europeu desde as últimas décadas do século XIX até a primeira Grande Guerra, tendo o respaldo dos homens de letras do maior prestígio na época, como Renan, Taine ou Anatole France.

Isto, não obstante, como já salientei, ele não conseguia superar sua adesão à 'lei dos três estados' de Comte, apesar de Herbert Spencer ter passado a ser o pensador de sua predileção. Assiste, com efeito, razão a Clóvis Moura quando aponta Spencer como o principal centro de referência do pensamento euclidiano.

Outra questão que aparece no texto de Mônica Velloso e merece uma discussão mais aprofundada está relacionada à forma como positivismo e evolucionismo, muitas vezes, são citados, quase como sinônimos. Mônica Velloso, ainda no texto mencionado acima, ao descrever Euclides, também chama a atenção para sua suposta postura 'positivistaevolucionista, ${ }^{29}$. Como já foi dito, e será reafirmado a partir da definição dos dois conceitos, positivismo e evolucionismo são duas doutrinas distintas e, em certos pontos, irreconciliáveis. Apesar de compartilharem algumas idéias comuns, como a da metodologia científica, que, aliás, estava presente em todo o conhecimento científico da época, positivismo e

\footnotetext{
${ }^{27}$ CANDIDO, Antonio. O método crítico de Silvio Romero. São Paulo: Ed. da Universidade de São Paulo, 1988.
}

${ }^{28}$ REALE, Miguel: Face Oculta de Euclides da Cunha. Rio de Janeiro: Topbooks, 1993, p. 46-47. 
evolucionismo se afastam em pontos cruciais, o que torna problemática essa definição de um intelectual como sendo, ao mesmo tempo, positivista e evolucionista. Isso não quer dizer que não houvesse intelectuais que não fossem nem positivistas e nem evolucionistas, mas que destacassem das duas teorias aquilo que mais lhes agradasse. Isso provavelmente ocorria, e pode mesmo ter acontecido com Euclides da Cunha. No entanto, quando se analisa a sua produção bibliográfica, é possível encontrar uma série de afirmações, análises e inflexões que ligam o escritor ao evolucionismo, o que não acontece em relação ao positivismo ortodoxo de Auguste Comte. Apesar de Euclides ter escrito, no período em que esteve envolvido pela filosofia positivista, artigos tecendo elogios à religião da Humanidade, não há, na produção bibliográfica euclidiana, indícios claros da utilização, por parte de Euclides da Cunha, dos preceitos teóricos positivistas.

Apesar disso, quando se analisa a historiografia sobre o escritor, são constantes as afirmações de que ele seria um positivista. É essa afirmativa que se pretende tentar esclarecer nesse capítulo inicial.

\subsection{Positivismo e evolucionismo: semelhanças e diferenças}

Criado, ou como afirmam muitos de seus seguidores e dissidentes, sistematizado por Augusto Comte, o positivismo surge na França da década de 20 do século XIX e tem como idéias principais a lei dos três estados, a hierarquia dos conhecimentos e o encadeamento dos fatos históricos a partir de uma perspectiva temporal evolutiva, o que minimiza a margem de ação dos seres humanos na história, uma vez que, independente de nossas vontades, os fatos desenrolar-se-ão de acordo com as leis gerais que regem os acontecimentos no mundo ${ }^{30}$. Propõe, neste sentido, uma lei positiva que, supostamente, preside a História. Essa característica do positivismo é comum a outras teorias científicas da época, entre elas o evolucionismo.

\footnotetext{
${ }^{29}$ VELLOSO, Mônica Pimenta. O modernismo e a questão nacional. In: FERREIRA, Jorge; DELGADO, Lucília de Almeida Neves (Org.). O Brasil republicano. Rio de Janeiro: Civilização Brasileira, 2003, p.357. ${ }^{30}$ COSTA, João Cruz, Contribuição a história das idéias no Brasil: o desenvolvimento da filosofia no Brasil e a evolução histórica nacional. Rio de Janeiro J. Olympio, 1956, p.86.
} 
No entanto, apesar de, nesse aspecto, restringir a autonomia de ação do homem, a doutrina positivista prima pela proposição da ação, e não pela contemplação, ou seja, deseja estudar somente aquilo que possa ser comprovado cientificamente e que seja resultado de ações concretas, e não de abstrações. Isso quer dizer, por exemplo, que para um positivista, o que interessava era resolver ou amenizar os conflitos de classe, um dado concreto da sociedade francesa do século XIX e resultado da ação de seres humanos, e não identificar as causas desse problema ${ }^{31}$. Para isso, o autor propunha a proteção dos mais fracos pelos mais fortes e a criação de leis sociais e trabalhistas, de modo a dignificar a pobreza e a proteger o trabalhador. Comte não se pronunciou sobre as causas reais desses conflitos, nem culpabilizou os industriais ou o grande capital por isso. Auguste Comte, ao contrário, atribuía um papel fundamental aos industriais no processo de evolução da humanidade. De acordo com José Arthur Giannotti, autor do prefácio à edição brasileira do livro "Os Pensadores" 32 sobre Auguste Comte: "Em Suma, o espírito positivo, segundo Comte, instaura as ciências como investigação do real, do certo e indubitável, do precisamente determinado e do útil.”

As abstrações pertenceriam ao campo metafísico, que, segundo a própria lei dos três estados, seria um estágio ultrapassado da humanidade, quando os homens, que ainda não tinham a ciência como instrumento de compreensão do mundo, recorriam a explicações abstratas, crenças, ou razões metafísicas para entendê-lo. Dessa forma, para os adeptos dessa escola, o que não pode ser comprovado empiricamente não é ciência e, por isso, não é considerado relevante para o progresso da humanidade. Nas palavras de João Ribeiro Junior, autor do livro O que é positivismo? $?^{33}$ : "O positivismo é, portanto, uma filosofia determinista que professa, de um lado, o experimentalismo sistemático e, de outro, considera anticientífico todo o estudo das causas finais"

Considerando-se apenas as afirmações feitas acima, Euclides da Cunha poderia perfeitamente ser considerado um positivista, já que compartilhava de muitas das idéias sistematizadas por Comte, como a da análise da história a partir de uma perspectiva evolutiva, da pesquisa empírica dos fatos, sem investigação de causas finais e da própria valorização do conhecimento científico, tido como o único legítimo.

\footnotetext{
${ }^{31}$ ALONSO, Ângela. Reforma, Ordem e Progresso. Revista Nossa História, Rio de Janeiro, v. 27, p. 68, 10 jan. 2007.

${ }^{32}$ CIVITA, Victor (Edit.). Os pensadores: Auguste Comte. 2. ed. São Paulo: ABRIL CULTURAL, 1983, p.15.

33 JUNIOR, João Ribeiro. O que é Positivismo? São Paulo, Brasiliense, 2003, p. 24.
} 
No entanto, essas idéias não foram criadas por Comte, nem eram exclusividade do pensamento positivista. Como disse Stuart Mill $^{34}$, Comte se caracterizaria mais como um sistematizador de conhecimentos do que um descobridor dos mesmos. O que ele fez foi, a partir de influências como a dos iluministas e de filósofos como Hegel, sistematizar o que estava sendo dito em termos de ciência em sua época e rotular tais conhecimentos com o nome de positivismo.

As idéias de progresso, de leis da história, de importância da ciência e de análise empírica dos acontecimentos continuaram, portanto, fazendo parte do senso comum no meio científico da época, e outros preceitos científicos, que não o positivismo, também se utilizaram delas para formular suas doutrinas ${ }^{35}$.

Desse modo, de acordo com Cruz $\operatorname{Costa}^{36}$, o positivismo se distingue de outras correntes científicas basicamente por três-_pontos:

1) A lei dos três estados;

2) A classificação das ciências e,

3) O catecismo positivista.

Este último foi uma tentativa de Augusto Comte de criar uma religião da humanidade. Para tanto, o autor utilizou, dando novo significado, muitos dos rituais e normas da Igreja Católica, como por exemplo, o batismo, o matrimônio, o apostolado, a criação de um novo calendário, de santos e de dias santos. Comte justificava tal apropriação dizendo que, de acordo com a lei dos três estados, o estado científico era posterior, mas herdeiro do estado teológico, e por isso os mesmos rituais poderiam ser utilizados, embora o grande objeto de devoção fosse a ciência, e não Deus ${ }^{37}$. Essa é uma das idéias de Comte que foi alvo de duras críticas por parte

\footnotetext{
${ }^{34}$ Idem Ibidem, p.95.

${ }^{35}$ SOUZA FILHO, Danilo Marcondes de. Iniciação à história da filosofia: dos pré-socráticos a Wittgenstein. 8. ed. Rio de Janeiro: J. Zahar, 2004.

${ }^{36}$ COSTA, João Cruz, Contribuição a história das idéias no Brasil: o desenvolvimento da filosofia no Brasil e a evolução histórica nacional. Rio de Janeiro J. Olympio, 1956, p.156.

${ }^{37}$ Idem Ibidem, p. 150-180.
} 
de Silvio Romero, assim como de Euclides da Cunha. Sobre esse assunto, Silvio Romero afirma $^{38}$ :

\begin{abstract}
A instituição de um novo dogma religioso e a conseqüente organização de um novo poder espiritual devidamente exercido por um novo clero, segundo o modelo católico feudal, que é o chefe d' oeuvre politique de La sagesse humaine, eis o grande desideratum atingido por Auguste Comte, no pensar de seus sectários.

Deixou de pé os altares; apenas tirou fora dele o Deus de São Paulo e o substituiu pelo Ser Supremo, cuja revelação máxima recebeu Clotilde de Vaux, isto é, a humanidade arvorada assim em objeto de seu próprio culto.
\end{abstract}

Já João do Rio, em crônica anteriormente citada, possui uma visão mais positiva dessa característica do apostolado positivista. Em um trecho de sua crônica, o cronista escreve: ${ }^{39}$ - Que é positivismo? Sussurro eu, sentando-me.
- É uma religião que respeita as religiões passadas e substitui a revelação
pela demonstração. Nasceu da ruptura do catolicismo e da evolução
científica do século XVII para cá. De Maistre dizia que o catolicismo ia
passar por muitas transformações para ligar ciência e religião. Comte
descobriu a lei dos três estados, a chave da Sociologia, e quando era o
grande filósofo, Clotilde apareceu e ensinou que a inteligência é apenas o
ministro do coração."

Outra idéia muito importante presente no catecismo positivista, que vai de encontro ao evolucionismo, é a proteção dos mais fracos pelos mais fortes. De acordo com Comte, os mais aptos, ou seja, os mais fortes, deveriam se encarregar de proteger os mais fracos, de modo a conservar a ordem social e a harmonia. A idéia era dignificar a pobreza, e não eliminá-la ${ }^{40}$.

Comte, que viveu na França de 1848 e chegou a ser discípulo de Saint Simon, tendo depois rompido com ele, estava, com essas idéias, pensando em uma forma de manter o proletariado longe de idéias extremadas e do que ele parecia ver como desordem. Para manter a ordem

\footnotetext{
${ }^{38}$ ROMERO, Silvio. Doutrina contra Doutrina. O evolucionismo e o positivismo na república do Brasil. Rio de Janeiro. Editor J.B Nunes.1894, p.11.

${ }^{39}$ DO RIO, João. A Igreja Positivista. Disponível em: http://pt.wikisource.org/wiki/A_Igreja_Positivista. Acesso em Agosto/2009.

${ }^{40}$ ALONSO, Ângela. Reforma, Ordem e Progresso. Revista Nossa História, Rio de Janeiro, v. 27, p. 68, 10 jan. 2007.
} 
social, e para que a camada menos favorecida da sociedade não se levantasse pedindo igualdade social era necessário criar mecanismos de dignificação da pobreza, de satisfação das necessidades mínimas dessa população. Comte estava, portanto, longe de ser um revolucionário, alguém que propusesse a eliminação das diferenças entre classes sociais ou do direito de propriedade. Esse ponto é outro alvo de críticas de Romero, que afirma o seguinte sobre a religião da humanidade de Comte: ${ }^{41}$ :

Preceitos morais, que subordinam o espírito ao coração, plantando nele o altruísmo, que da parte do rico se chama proteção, da parte do pobre se denomina obediência e veneração... É muito bom de dizer e o cristianismo durante quase mil e novecentos anos não tem dito outra coisa.

No entanto, a teoria comtiana estava mais longe ainda de ser parecida com a evolucionista social, já que essa doutrina, formulada por Spencer, defendia a idéia da seleção natural das espécies, criada por Darwin para descrever apenas o comportamento animal, mas que para os evolucionistas sociais spencerianos deveria ser aplicada também aos seres humanos. Como já foi dito, o principal livro de Darwin foi publicado alguns anos após a morte de Comte. Por isso, nem Darwin nem Spencer poderiam ter exercido qualquer tipo de influência na obra e no pensamento de Comte. Spencer, que tinha Malthus como principal matriz teórica, acreditava que também entre os homens imperava a lei dos mais fortes ${ }^{42}$. Para ele, os mais fortes sobrevivem, os mais fracos tenderiam a desaparecer. E não se deveria ter pena daqueles que são mais fracos, fazer caridade ou dar esmolas para sua manutenção, que em nada ajudaria o progresso da humanidade. Eles deveriam, mesmo, desaparecer. O meio regularia quem deve sobreviver ou ser extinto. Não se deveria interferir na ordem natural das coisas.

Assim como Malthus, Spencer também argumentava que a guerra era benéfica, na medida em que regulava automaticamente quem deveria viver ou não. Além disso, outra idéia importante que Spencer utilizou da teoria de Darwin era a da luta pela vida ${ }^{43}$. Segundo Spencer os homens viviam em constante competição, a qual não poderia ser cerceada por mecanismos estatais. A competitividade seria inerente à luta pela vida na qual os homens estão engajados, e qualquer tentativa de interferir nessa competição poderia alterar os resultados que seriam

\footnotetext{
${ }^{41}$ ROMERO, Silvio. Doutrina contra Doutrina. O evolucionismo e o positivismo na república do Brasil. Rio de Janeiro. Editor J.B Nunes.1894, p.106.

${ }^{42}$ VELA, Fernando. Abreviatura de Princípios de Sociologia de H. Spencer. Buenos Aires: Revista de Occidente Argentina, 1947.

43 ROMERO, Silvio. Doutrina contra Doutrina. O evolucionismo e o positivismo na república do Brasil. Rio de Janeiro. Editor J.B Nunes.1894, p. 206.
} 
alcançados caso a "natureza" tivesse sido respeitada ${ }^{44}$. Como se pode ver, Spencer era um entusiasta do liberalismo, muito diferente da idéia de ditadura republicana e da presença do estado como regulador da ordem social, como aparece em Comte.

Portanto, como conciliar a proteção dos mais fracos pelos mais fortes, de Comte, com a seleção natural de Spencer? Mais ainda, como equacionar a ordem social com a 'desordem' causada pela competitividade entre os homens, em constante luta pela vida? De acordo com Ângela Alonso, professora da $\mathrm{USP}^{45}$ :

No catecismo positivista (1852), Comte apresentava uma religião civil -o catolicismo laico da Religião da Humanidade - e prescrevia um darwinismo às avessas: a proteção do mais fraco pelo mais forte. Políticas sociais compensariam a desigualdade social e reduziriam o antagonismo político da sociedade moderna entre proletários e patrícios. O sistema de política positiva (1851-4) defendia um regime republicano-presidencialista centralizado, inspirado na república romana. Comte não vinha promover a revolução, mas evitá-la.

Outro ponto importante de diferenciação entre as doutrinas diz respeito à questão racial: é verdade que Comte alude aos mais fracos e mais fortes em sua doutrina, o que nos leva a pensar que ele estivesse de acordo com as teorias raciais de sua época. No entanto, Comte não se pronuncia, em momento algum a respeito da questão racial nos moldes spencerianos, já que ele não define quem seriam os mais fracos ou os mais fortes ${ }^{46}$. Spencer, ao contrário, o faz claramente, dizendo existirem raças mais aptas ao desenvolvimento que outras ${ }^{47}$.

Ainda sobre o evolucionismo, a questão da adaptação ao meio e do meio como determinante, apontadas por Velloso ${ }^{48}$ como característica da geração de 1870, é um traço, mais uma vez, do evolucionismo, e não do positivismo. De acordo com a teoria spenceriana ${ }^{49}$, a idéia de adaptação ao meio é essencial na luta pela vida, na seleção natural. Só os mais adaptados sobrevivem. Essa importância atribuída ao meio não é monopólio do que é chamado de determinismo geográfico. O meio atua como um estímulo para a evolução dos caracteres dos

\footnotetext{
${ }^{44}$ VELA, Fernando. Abreviatura de Princípios de Sociologia de H. Spencer. Buenos Aires: Revista de Occidente Argentina, 1947.

${ }^{45}$ ALONSO, Ângela. Reforma, Ordem e Progresso. Revista Nossa História, Rio de Janeiro, v. 27, p. 68, 10 jan. 2007.

${ }^{46}$ OLIVEIRA FILHO, Benjamin de. A filosofia social de Augusto Comte. Rio de Janeiro: Haddad, 1954.

${ }^{47}$ SPENCER, Herbert. Introduction a la science sociale. Ed. Paris: F. Alcan, 1908, p.225.

${ }^{48}$ VELLOSO, Mônica Pimenta. A literatura como espelho da nação. Estudos Históricos, Rio de Janeiro, vol.1, n.2, 1988.
} 
seres vivos. Segundo a doutrina spenceriana mais fidedigna a Lamarck e a Darwin, estas características adquiridas seriam herdadas pelas próximas gerações. O meio seria, portanto, um fator determinante como indutor de mudanças nos habitantes de um meio natural ${ }^{50}$.

\subsection{O pensamento euclidiano e suas matrizes.}

A partir da distinção entre positivismo e evolucionismo, uma outra questão se apresenta: por que Euclides da Cunha é conhecido como positivista, e não como evolucionista apesar de a maior parte de suas idéias, como a que resume na célebre afirmação de que "estamos condenados à civilização" 51 e a de que "o sertanejo é, antes de tudo, um forte",52 porque descende de bandeirantes brancos, serem claramente tributárias do evolucionismo? Antes de responder à pergunta, faz-se necessário demonstrar, com mais clareza, os motivos que levam a considerar, neste trabalho, sua produção literária, mais especificamente sua obra maior, Os Sertões, como uma obra de influência, sobretudo, evolucionista spenceriana.

A segunda parte do livro, intitulada “O Homem" 53, pode ser lida como um tratado spenceriano. Nessa parte, o autor utiliza fartamente os conceitos de seleção natural, evolução das espécies, e adaptação ao meio para explicar a força do sertanejo. Além disso, ele cita explicitamente, em vários momentos, Spencer. ${ }^{54} \mathrm{~A}$ idéia de Euclides não era a de glorificar o sertanejo, nem de defendê-lo, como parece interpretar, por vezes, o senso comum. Euclides da Cunha acreditava nos males da miscigenação, e na inferioridade do mestiço. No entanto, ele tinha que explicar, cientificamente, como aqueles sertanejos degenerados tinham vencido três expedições do exército nacional, expressão da civilização e do progresso, durante a guerra de Canudos. Daí a criação de suas teorias defendendo o mestiço do interior em contraposição ao mestiço do litoral, esse sim um degenerado. De acordo com Costa Lima, em livro intitulado Euclides da Cunha: Contrastes e Confrontos do Brasil ${ }^{55}$, a euforia de Euclides e a certeza que

\footnotetext{
${ }^{49}$.Idem Ibidem, p. 308.

${ }^{50}$ SOUZA, Sandro de. A goleada de Darwin. Rio de Janeiro, Ed. Record, 2009, p.158.

${ }^{51}$ CUNHA, Euclides. Os sertões Ed. critica São Paulo Ed. Ática, 1985, p.71.

${ }^{52}$ Idem. Ibidem, p.105.

${ }^{53}$ Idem. Ibidem.

${ }^{54}$ Idem. Ibidem.

| 55 APUD LIMA, Luiz Costa. Euclides da Cunha: Contrastes e confrontos do Brasil. Rio de Janeiro: Contraponto/NUSEG, 2000, p.22.
} 
o escritor tinha da vitória dos republicanos frente a um bando de degenerados vão se transformando em incredulidade à medida que os sertanejos resistem ao cerco de Canudos. Desse modo, todo o tom pejorativo com que Euclides descreveu o sertanejo em seu Diário de uma Expedição ${ }^{56}$ é, de certa forma, amenizado em Os Sertões, que, ainda assim, contém uma boa dose de evolucionismo. Nas palavras do autor: “(...) A rapidez da vitória é sempre adiada e o entusiasmo dos que de antemão se criam vencedores contrasta com o desfile dos feridos e combalidos que regressam da frente de batalha". 57

E mais adiante:

\begin{abstract}
A incapacidade do mais moderno equipamento militar em aniquilar um adversário, inequivocamente inferior, além da incrível capacidade de resistência deste forçam Euclides a se indagar quem é este homem, o sertanejo, que não fraqueja. Já não lhe basta descrevê-lo como bruto $e$ ignorante. $^{58}$
\end{abstract}

Um trecho destacado do artigo “A Nossa Vendéia”, escrito por Euclides no calor da guerra e que se tornaria muito conhecida, pelo fato de Euclides ter comparado os conselheiristas aos ‘retrógrados’ da cidade de Vendéia, que se opuseram à Revolução Francesa, demonstra bem o tom inicial do escritor a respeito da guerra de Canudos. De acordo com o autor ${ }^{59}$ :

Identificados à própria aspereza do solo em que nasceram, educados numa rude escola de dificuldades e perigos, esses nossos patrícios do sertão, de tipo etnologicamente indefinido, refletem naturalmente toda a incostância e toda a rudeza do meio em que se agitam.

O homem e o solo justificam assim e de algum modo, sob um ponto de vista geral, a aproximação histórica expressa no título deste artigo. Como na Vendéia o fanatismo religioso que domina as suas almas ingênuas e simples é habilmente aproveitado pelos propagandistas do império. (...)

A justeza do paralelo estende-se aos próprios revezes sofridos. A Revolução Francesa que se aparelhava para lutar com a Europa, quase sentiu-se impotente para combater os adversários impalpáveis da Vendéia- heróis intangíveis que se escoando céleres através das charnecas prendiam as forças republicanas em inextricável rede de ciladas...

\footnotetext{
${ }^{56}$ CUNHA, Euclides. Obra Completa. Rio de Janeiro: Nova Aguillar, 1966.

57 APUD LIMA, Luiz Costa. Euclides da Cunha: Contrastes e confrontos do Brasil. Rio de Janeiro: Contraponto/ NUSEG, 2000 p.15.

${ }^{58}$ Idem. Ibidem, p.22.

${ }^{59}$ DA CUNHA, Euclides. A Nossa Vendéia. Disponível em:

http://pt.wikisource.org/wiki/A_nossa_vend\%C3\%A9ia_(1). Acesso em: Agosto/ 2009.
} 
Este paralelo será, porém, levado às últimas conseqüências: a República sairá triunfante desta ultima prova.

Desse modo, Euclides da Cunha ainda estava convencido, mesmo após três derrotas seguidas do exército republicano, da inevitabilidade da vitória republicana ao fim e ao cabo. Suas convicções científicas lhe garantiam essa certeza ${ }^{60}$. Ainda de acordo com Costa Lima, seu argumento sobre o conflito só vai começar a se modificar quando o autor presencia de perto os acontecimentos e os horrores cometidos pelos republicanos civilizados. A partir daí, o autor se filia à idéia do autoctonismo das raças americanas e acaba por enveredar por uma variante da teoria científica que preside sua análise do social, ao justificar a maior pureza do sertanejo a partir da ausência de contato e miscigenação do sertanejo com outras raças. Assim, isolado, o sertanejo teria conservado uma certa pureza racial e desenvolvido caracteres próprios a essa nova raça, como a valentia e o vigor físico. Esses atributos o fariam mais valoroso do que o mestiço do litoral, este sim, em constante contato e miscigenação com outras raças e por isso, um degenerado. O sertanejo não seria, portanto, um ser inferior, mas apenas um retrógrado, um atrasado, que estaria em uma fase histórica anterior a nossa. Nesse sentido, para Euclides, a solução do problema do sertanejo no Brasil não seria a aniquilação dos mesmos, como foi feito em Canudos, mas sim a escolarização dessas pessoas, de forma a colocá-las em harmonia com o momento histórico, com o progresso e com a civilização, que seriam os caminhos do científico e do republicano.

Outra idéia interessante que aparece na teoria euclidiana sobre o sertanejo, e que tem correlação com o evolucionismo, é a da adaptação ao meio. De acordo com o escritor, no meio em que ele vive, o jagunço é o tipo mais adaptado, aquele que melhor consegue sobreviver. Em um meio como este, os jagunços levam, de fato, muito mais vantagens do que os civilizados, como ocorreu na guerra de Canudos. Os civilizados, ainda de acordo com Euclides, não estão adaptados a um meio que exige dos homens resistência a temperaturas e condições adversas, vigor físico e ligeireza de movimentos. Eles estão adaptados a um meio que demanda aptidões intelectuais, e esse teria sido um dos motivos dos repetidos fracassos do exército brasileiro em Canudos. Portanto, Canudos também foi, para Euclides, um campo de aplicação de suas teorias evolucionistas para a explicação da sociedade. Ao invés provocar a reflexão e o questionamento de suas conviç̧ões, já que a ‘civilização’ quase não conseguiu

${ }^{60}$ LIMA, Luiz Costa. Euclides da Cunha: Contrastes e confrontos do Brasil. Rio de Janeiro: Contraponto/ NUSEG, 2000, p.19. 
vencer a 'barbárie', Canudos serviu pra Euclides da Cunha como uma forma de reafirmar toda a sua crença nas teorias evolucionistas em voga naquele momento, como é possível perceber na no trecho de 'Os Sertões' destacado abaixo:

\begin{abstract}
A seleção natural, em tal meio, opera-se à custa de compromissos graves com as funções centrais do cérebro, numa progressão inversa prejudicialíssima entre o desenvolvimento intelectual e o físico, firmando inexoravelmente a vitória das expansões instintivas e visando o ideal de uma adaptação que tem como conseqüências únicas, a máxima orgânica, a mínima fortaleza moral. A aclimação traduz uma evolução regressiva. $O$ tipo deprece num esvaecimento contínuo, que se lhe transmite à descendência até a extinção total. Como o inglês nas Barbadas, na Tasmânia, ou na Austrália, o português no Amazonas, se foge ao cruzamento, no fim de poucas gerações tem alterados os caracteres físicos e morais de uma maneira profunda, desde a tez, que se acobreia pelos sóis e pela eliminação incompleta do carbono, ao temperamento, que se debilita despido das qualidades primitivas. A raça inferior, o selvagem bronco, domina-o; aliado ao meio vence-o, esmaga-o, anula-o, na concorrência formidável ao impaludismo, ao hepatismo, às pirexias esgotantes, às canículas abrasadoras, e aos alagadiços maleitosos. ${ }^{61}$
\end{abstract}

Dessa maneira, Euclides utilizou todo o seu arcabouço científico para definir o sertanejo como um possível cerne da nacionalidade. Cerne não no sentido de principal, mas no de primeiro, ou primitivo. Ainda de acordo com Costa Lima:

(...) Cerne porque mais próximo da origem do que os litorâneos, sujeitos ao contato com os forasteiros; cerne porque habitante do mais interior de nosso solo e descendente dos primeiros cruzamentos aí efetuados. ${ }^{62}$.

A intimidade de Euclides com as idéias spencerianas de sua época parece, portanto, bastante clara, como pode ser percebido em algumas de suas palavras escritas em “Os Sertões”:

A mistura de raças muito diversas é, na maioria dos casos, prejudicial. Ante as conclusões do evolucionismo, ainda quando reaja sobre o produto o influxo de uma raça superior, despontam vivíssimos estigmas da inferior. A mestiçagem extremada é um retrocesso. $O$ indo-europeu, o negro e o brasílio-guarani ou o tapuia, exprimem estádios evolutivos que se fronteiam, e o cruzamento, sobre obliterar as qualidades preeminentes do primeiro, é um estimulante à revivescência dos atributos primitivos dos últimos. ${ }^{63}$

E mais adiante:

\footnotetext{
${ }^{61}$ CUNHA, Euclides. Obra Completa. Rio de Janeiro. Nova Aguillar, 1966, p.79.

${ }^{62}$ LIMA, Luiz Costa. Euclides da Cunha: Contrastes e confrontos do Brasil. Rio de Janeiro: Contraponto/ NUSEG, 2000, p.19.
} 
É que, nessa concorrência admirável dos povos, envolvendo todos em luta sem tréguas, na qual a seleção capitaliza atributos que a hereditariedade conserva, o mestiço é um intruso. Não lutou; não é uma integração de esforços; é alguma coisa de dispersivo e dissolvente; surge, de repente, sem caracteres próprios, oscilando entre influxos opostos de legados discordes. A tendência à regressão às raças matrizes caracteriza a sua instabilidade. ${ }^{64}$

Como se vê, Euclides estava muito afinado com as teorias do evolucionismo e, portanto, a idéia de um Euclides eminentemente positivista parece, mesmo, uma construção historicamente datada. Mas porque essa construção e em que momentos ela começou a ganhar corpo?

A primeira resposta possível é a que associa os intelectuais, diretamente, às suas formações acadêmicas. Euclides da Cunha foi aluno do curso de engenharia da Escola Militar e teve, entre seus professores, o conhecidíssimo positivista Benjamim Constant. A Escola Militar, na época em que Euclides esteve matriculado como aluno, foi um grande e reconhecido local de difusão da doutrina positivista, e foi dessa escola que saíram muitos proclamadores da República, entre eles o próprio Benjamim Constant. É conhecida a afirmação de que o lema de nossa bandeira, “Ordem e Progresso", é uma manifestação direta da influência do positivismo no republicanismo da primeira hora, assim como a separação entre a igreja e o estado e a laicização dos cemitérios, todas as medidas tomadas durante a gestão militar de nossa ainda incipiente república. Desse modo, Euclides da Cunha teria sido formado intelectualmente em um ambiente de propagação das idéias positivistas, o que, por si só, já seria uma garantia de que ele era, de fato, um positivista. No entanto, não é isso que demonstram os próprios escritos do autor. Em trecho do artigo “Da independência à república”, Euclides da Cunha afirma que:

(...) em verdade, o que houve foi a transfiguração de uma sociedade em que penetrava pela primeira vez o impulso tonificador da filosofia contemporânea. E esta, certo, não a vamos buscar nesse tão malsinado positivismo, que aí está sem a influência a que se empresta, cristalizado na alma profundamente incorruptível de Teixeira Mendes. ${ }^{65}$.

\footnotetext{
${ }^{63}$ Idem. Ibidem, p.100.

${ }^{64}$ Idem. Ibidem, p.101.

${ }^{65}$ Idem. Ibidem, p. 678.
} 
Euclides, em várias de suas crônicas, escritas para o Jornal do Commercio e para O Estado de São Paulo, fez questão de declarar que não era um positivista ${ }^{66}$. Entretanto, isso não invalida a tese de que ele sofreu, durante o início de sua vida intelectual, influência do positivismo, e nem é isso o que este trabalho pretende sustentar. Tendo formação científica, e atento ao que de mais novo se produzia na comunidade científica de sua época, Euclides sofreu sim a influência do positivismo, mas, certamente, não foi essa doutrina a única a influenciar seu pensamento, e nem a mais relevante dentre todas as correntes filosóficas a que Euclides se filiou. Os traços do evolucionismo, na obra euclidiana são muito mais marcantes. A questão é, portanto, entender em que momento essa identidade entre Euclides e o evolucionismo foi apagada em benefício da construção de uma outra identidade intelectual, que associou muito diretamente o escritor à doutrina de Augusto Comte.

Outra hipótese sobre essa construção leva em consideração o fato de que, na década de 30, teorias raciais como as utilizadas por Euclides para explicar o sertanejo já não tinham tanta aceitação como na época em que Euclides escreveu seu livro principal.

A partir desse momento, as teses socio-culturais começaram a ganhar espaço nos meios acadêmicos. Antropólogos como Franz Boas, que influenciaram importantes intelectuais brasileiros, como Gilberto Freire e Roquette Pinto, passaram a atribuir os males sofridos pelas supostas raças inferiores a questões de cunho social, e não raciais. Desse modo, a partir desse momento, as mazelas dos povos supostamente inferiores passaram a ser explicadas por questões como a fome, a falta de instrução, a falta de estrutura familiar e a insalubridade em que viviam, ainda que continuassem a existir estudos e explicações baseadas em teorias raciais. Explicações como as que parecem presidir a interpretação de Euclides não seriam mais tão aceitas nos meios acadêmicos como nos tempos de Euclides. Roquette-Pinto, um dos principais nomes do movimento de glorificação de Euclides, era assumidamente contrário à tese evolucionista de Lamarck, utilizada e citada por Euclides ${ }^{67}$, e à idéia da desigualdade entre as raças, como destacam Vanderlei e Abreu:

A partir do final da década de 1920, no entanto, as concepções lamarckistas começaram a ser seriamente questionadas por alguns intelectuais brasileiros ligados ao discurso eugenista. Já na conferência de abertura do Primeiro Congresso Brasileiro de Eugenia, Roquette-Pinto, presidente e

\footnotetext{
${ }^{66}$ Idem. Ibidem.

${ }^{67}$ CUNHA, Euclides. Obra Completa. Rio de Janeiro. Nova Aguillar, 1966.
} 
orador do evento, elaborava uma enfática critica as concepções
lamarckistas $(\ldots)^{68}$

Embora abominasse a teoria das desigualdades raciais, Roquette-Pinto ainda apontava diferenças entre os mestiços do litoral $e$ os do interior, valorizando os últimos em detrimento dos primeiros. ${ }^{69}$

Regina Abreu também menciona a queda de aceitação das teorias que são utilizadas na obra de Euclides nos meios intelectuais. De acordo com a autora ${ }^{70}$ :

\begin{abstract}
O livro do engenheiro Euclides da Cunha se tornaria um divisor de águas. Símbolo de uma proposta de literatura científica, só foi destronado no final dos anos 30, quando uma nova sociologia começou a ser produzida no país. Até então, permaneceu como modelo de boa ciência associada à literatura. $E$, mesmo após ter deixado de ser uma referência no campo intelectual, permaneceu como monumento nacional, como um dos livros cuja leitura é imprescindível para aqueles que querem conhecer o Brasil.
\end{abstract}

Ora, foi exatamente nesse momento que, segundo Regina Abreu, em livro intitulado “ $O$ Enigma de Os Sertões” "71, os movimentos de valorização e glorificação de Euclides da Cunha do Rio de Janeiro e de São José do Rio Pardo começaram a ganhar força, tendo este último começado a receber subvenções do estado de São Paulo e a contribuição de intelectuais renomados, como Gilberto Freire, José Lins do Rego, Plínio Salgado, ou Lúcia Miguel Pereira, entre outros. Foi nesse momento que as iniciativas em homenagem a Euclides renderam frutos e conquistaram reconhecimento nacional. Apesar de não ter tido tanta popularidade no Rio de Janeiro quanto em São José do Rio Pardo, o movimento euclidiano do Rio começava a se fortalecer de maneira considerável, graças à rede de relações e de influência construída pelos euclidianos do rio, que garantiu não ao Grêmio, mas à obra de Euclides da Cunha uma divulgação e circulação sem precedentes. Dessa maneira, consideramos que se esses intelectuais pretendiam, de fato, glorificar, exaltar e popularizar o escritor, nada mais inapropriado do que ressaltar suas características evolucionistas nessa época. Uma hipótese deste trabalho é que esse lado do escritor pode ter passado, então, a ser silenciado pelos intelectuais. Esses intelectuais pretendiam exatamente não deixar que a obra euclidiana fosse destronada, como menciona Regina Abreu, e parecem ter sido bem

\footnotetext{
${ }^{68}$ SOUZA, Vanderlei Sebastião de. A Eugenia no Brasil: Ciência e pensamento social no movimento eugenista brasileiro no entre - guerras. Disponível em: http://www.anpuh.uepg.br/xxiiisimposio/anais/textos/Vanderlei\%20Sebasti\%C3\%A30\%20de\%20Souza.pdf. Acesso em Agosto/2009.

${ }^{69}$ ABREU, Regina. O enigma de Os Sertões. Rio de Janeiro: Rocco, 1988, p 306.

${ }^{70}$ Idem Ibidem, p.262.

${ }^{71}$ Idem Ibidem.
} 
sucedidos, uma vez que, embora tenha deixado de ser um livro de referência no campo científico, "Os Sertões" permaneceu e consolidou a sua posição de clássico nacional na década de 30. Para isso, foi fundamental o trabalho dos euclidianos ressaltados.

Finalmente, após anos de silêncio a respeito das teorias científicas utilizadas por Euclides em seus escritos, essa memória, de fato, passou a ser desconsiderada, quase esquecida. Esse pode ser mais um dos chamados silêncios eloqüentes, que geralmente acontecem quando, intencionalmente, algumas coisas, no caso de Euclides sua identidade com o pensamento evolucionista spenceriano da época, passam a ser esquecidas em benefício de outras, que passam a ser ressaltadas.

A terceira e última hipótese, diz respeito, mais especificamente, à criação de um Euclides positivista a partir do Grêmio Euclides da Cunha do Rio de Janeiro, o que não anula as outras hipóteses, mas apenas as complementa. Sob esse ponto de vista, intelectuais ligados ao positivismo que, como veremos, ajudaram a fundar o Grêmio Euclides da Cunha, como Edgard Sussekind de Mendonça, Roquette - Pinto e Francisco Venâncio Filho, teriam ajudado a construir uma imagem de Euclides da Cunha positivista, muito similar à deles próprios, por meio de rituais de comemoração e adoração ao escritor que eram muito semelhantes àqueles praticados pelos positivistas em homenagem a seus vultos. Esses mesmos intelectuais, unidos a tantos outros filiados e simpáticos ao Grêmio Euclides da Cunha, estavam mais interessados em glorificar a figura de Euclides e destacar todas as suas qualidades, e não em analisá-la de forma crítica. Desse modo, o evolucionismo, tão presente em sua obra, teria ficado à margem ou até mesmo esquecido nos estudos sobre Euclides da Cunha feitos por euclidianos. Essa hipótese fundamenta o próximo capítulo.

Antes de encerrar esta primeira parte, é importante evocar, mais uma vez as palavras de Costa Lima:

(...) Lamentavelmente, a conversão de Os Sertões em objeto de glória e em símbolo fundador da nacionalidade tem impedido que seus analistas cumpram o que seria deles mais esperado: a explicitação dos problemas com que Euclides se depara e a precariedade de muitas de suas soluções. ${ }^{72}$

\footnotetext{
${ }^{72}$ LIMA, Luiz Costa. Euclides da Cunha: Contrastes e confrontos do Brasil. Rio de Janeiro: Contraponto/ NUSEG, 2000, p. 36.
} 


\section{CAPÍTULO II: A transformação de Euclides da Cunha em mito nacional}

\subsection{Euclides da Cunha: de engenheiro e jornalista a grande escritor da nação}

Nesse capítulo, será analisada a popularização e a glorificação da figura e da obra euclidianas não somente a partir da criação do Grêmio Euclides da Cunha do Rio de Janeiro, em 1911, mas a partir da própria publicação de “Os Sertões”, em 1902, que recebeu críticas muito favoráveis e transformou Euclides, de engenheiro e repórter praticamente desconhecido, em grande expoente da literatura nacional. Essas críticas tiveram um papel muito importante na consolidação do nome de Euclides da Cunha.

Na verdade, a literatura sobre o sertão não era exatamente uma novidade no momento em que foi publicado "Os Sertões”. Outros escritores, como Coelho Netto e Artur Azevedo também tinham o sertão como o tema principal de suas histórias. Esses escritores faziam parte de uma corrente que, segundo Regina Abreu $^{73}$, era valorizada por estar associada à autenticidade, pureza, sinceridade, ao contrário da literatura urbana, associada à contaminação, ao engano e à ilusão.

Desse modo, a busca pelo “cerne da nacionalidade” ${ }^{74}$, nas palavras do próprio Euclides, estava presente em outros escritores, que viam a literatura urbana dessa época como excessivamente contaminada por influências estrangeiras e pouco afeita a uma realidade genuinamente nacional ${ }^{75}$. Outro ponto importante a ser ressaltado diz respeito, especificamente, ao tema da guerra de Canudos: esse foi um conflito amplamente noticiado pelos jornais da época, e, além de Euclides, outros repórteres foram enviados para fazer a cobertura da guerra. Dentre eles, alguns também publicaram livros sobre o acontecimento, como o major Barreto Dantas, Manuel Benício e Olívio de Barros ${ }^{76}$.

\footnotetext{
${ }^{73}$ ABREU, Regina. O enigma de Os Sertões. Rio de Janeiro, Rocco, 1988, p.262.

${ }^{74}$ CUNHA, Euclides. Obra Completa. Rio de Janeiro. Nova Aguillar, 1966, p 342.

${ }^{75}$ VENTURA, Roberto. Euclides da Cunha: Esboço Biográfico. São Paulo, Cia das Letras, 2003.

${ }^{76}$ ABREU, Regina. O enigma de Os Sertões. Rio de Janeiro, Rocco, 1988, p. 165.
} 
Mas nenhum desses escritores fez tanto sucesso quanto Euclides da Cunha. Tamanho e tão repentino sucesso de um livro a respeito de um tema até certo ponto ultrapassado, já que no momento em que “Os Sertões” foi publicado, 1902, a guerra já havia terminado há alguns anos, mereceu uma investigação mais apurada de historiadores como Regina Abreu. Afinal, o livro de Euclides da Cunha é considerado, mesmo nos dias atuais, um livro de difícil leitura, em razão da quantidade de termos científicos que o autor utiliza ao longo de seu texto. Considerando-se que a maior parte do público leitor daquele período histórico não estava familiarizado com os termos, conceitos e teorias utilizados por Euclides da Cunha, como o seu livro conseguiu atingir um índice de vendas tão alto, já nos primeiros meses após a sua publicação? Por que, afinal, o livro de Euclides da Cunha fez tanto sucesso já na época de seu lançamento?

Segundo Regina Abreu, uma das explicações possíveis, ainda que não seja a única, pode estar relacionada à aprovação do livro por parte de alguns dos grandes críticos literários da época: José Veríssimo, Araripe Junior e Silvio Romero ${ }^{77}$. Os três literatos, que produziam importantes críticas sobre novos e antigos escritores e seus livros em grandes jornais da época, foram unânimes na aprovação do livro de Euclides. Mais do que isso: os três foram unânimes na aprovação do caráter científico do livro, que talvez diferenciasse a obra euclidiana da dos outros autores que haviam escrito sobre a guerra de Canudos. A crítica dos literatos ao livro de Euclides deixa bem clara a importância dada por eles ao caráter científico do livro. José Veríssimo, em 1902, escreveu o seguinte:

O livro do Sr: Euclides da Cunha, ao mesmo tempo um homem de ciência, um geógrafo, um geólogo, em etnólogo; de um homem de pensamento, um filósofo, um sociólogo, um historiador, e de um homem de sentimento, um poeta, um romancista, um artista, que sabe ver e descrever, que vibra e sente tanto aos aspectos da natureza como ao contato do homem... ${ }^{78}$

José Veríssimo, em sua análise sobre o livro de Euclides, fez questão de dar destaque à formação intelectual do autor. Veríssimo assinalou que o livro foi produzido por um homem de ciência, que era geógrafo, geólogo, etnólogo, filósofo e historiador, entre outras qualidades. Desse modo, para Veríssimo, por ser cientista além de escritor, é como se a narrativa de Euclides tivesse mais legitimidade do que as outras produzidas sobre esse mesmo

\footnotetext{
${ }^{77}$ Idem Ibidem.
} 
assunto. Sendo assim, apesar de a guerra de Canudos já ter sido objeto de outros estudos e de uma extensa cobertura jornalística para os padrões da época, o livro de Euclides da Cunha não poderia ser ignorado, pois fornecia uma visão diferenciada, de um homem de ciência, sobre aquele conflito ocorrido nos sertões brasileiros. Não é de se espantar que José Veríssimo tenha dado importância ao caráter científico do livro de Euclides da Cunha. Assim como Silvio Romero, e embora tenha discordado deste último em alguns pontos ${ }^{79}$, Veríssimo também era simpático às teorias e aos pensadores evolucionistas, que aparecem em profusão, seja por citações nominais, seja pela aplicação de suas idéias, no livro de Euclides. Essa característica do pensamento de Veríssimo é destacada por Maria Auxiliadora Cavazotti, em livro intitulado “O projeto republicano de educação nacional na versão de José Veríssimo”. No livro citado, a autora afirma que:

O perfil intelectual de Veríssimo encontra ressonância no pensamento social brasileiro à época republicana. As características de erudição, domínio científico e qualidade literária presentes em Veríssimo são compartilhadas por toda uma geração de intelectuais brasileiros- entre os quais $s$ denominada 'geração de 70'- que viveram e produziram no ocaso do século passado e início deste, ou seja, no período em que se gesta a república. ${ }^{80}$

Mais adiante, a autora afirma:

Mas é, principalmente, no pensamento de Spencer que Veríssimo vai buscar luzes. Nisso segue uma tendência da época, de cunho liberal, ligada às lutas republicanas. De fato, como lembra José Murilo de Carvalho, 'a versão final do século XIX na postura liberal era o darwinismo social, absorvido no Brasil por intermédio de Spencer. ${ }^{81}$

Ainda sobre Veríssimo, completa a autora:

Fica claro, assim, que é sob os auspícios da Biologia e da Sociologia, integradas no evolucionismo social spenceriano, que Veríssimo vai buscar os princípios com os quais busca fundamentar sua proposta de educação nacional. $^{82}$

1

Formatado: Fonte: Itálico, Cor da fonte: Automática

\footnotetext{
${ }^{78}$ APUD ABREU, Regina. O enigma de Os Sertões. Rio de Janeiro, Rocco, 1988, p.196.

${ }^{79}$ CAVAZOTTI, Maria Auxiliadora. O projeto republicano de educação nacional na versão de José Veríssimo. São Paulo; Annablume, 2003.

${ }^{80}$ Idem Ibidem, p. 40.

${ }^{81}$ Idem Ibidem, p. 55-56.

${ }^{82}$ Idem Ibidem, p. 57.
} 
Sobre Os Sertões, escreveu Araripe Junior que o livro de Euclides “(...) resulta da soma da arte com a ciência, do épico com o trágico, da emoção com a razão (...)” ${ }^{83}$. Essas palavras deixam claro que o caráter científico-literário do livro de Euclides da Cunha conferiu mais credibilidade e até mais legitimidade à narrativa de Euclides da Cunha sobre o sertão e sobre a guerra.

Regina Abreu confirma a importância dada pela trindade crítica do realismo ${ }^{84}$, na expressão da autora, ao caráter científico da obra euclidiana em diversas afirmações, entre as quais:

Apesar de desavenças pontuais, os três partilhavam idéias próximas e, sobretudo, ocupavam o mesmo lugar de representantes de novo método de crítica literária calcada em critérios científicos por oposição aos antigos métodos acusados de pecar por excesso de subjetivismo. ${ }^{85}$

Mais adiante, ao caracterizar a nova visão dos chamados críticos realistas, a autora afirma que:

\begin{abstract}
A literatura devia estar a serviço da 'realidade nacional', e os escritores, regidos por novos critérios de consagração, pautados por crítica moderna e científica. Romero expressava o ponto de vista de muitos dos excluídos da Rua do Ouvidor e das principais agências: arregimentar suas forças na novidade da ciência e com ela mudar os rumos da literatura. Esse movimento, que se processou a partir dos anos 70 do século passado, foi crucial não apenas para que um engenheiro como Euclides da Cunha viesse a produzir Os Sertões, bem como para que essa obra viesse a ser consagrada. A consagração de Os Sertões significaria o exercício da nova crítica que buscava se afirmar no país. O criador e a criatura se encontravam. Um alimentaria o outro. Tanto a crítica moderna e científica seria fundamental para a consagração de Os Sertões quanto o aparecimento de Os Sertões seria fundamental para o exercício e a afirmação da nova crítica. $^{86}$
\end{abstract}

Ainda sobre esse assunto, Regina Abreu ressalta que:

Como Araripe, Romero observava a importância dos estudos realizados sobre o meio físico, concordando com a visão determinista de que a terra moldava os homens à sua imagem e semelhança. ${ }^{87}$

\footnotetext{
${ }^{83}$ ABREU, Regina. O enigma de Os Sertões. Rio de Janeiro, Rocco, 1988, p. 198.

${ }^{84}$ Idem Ibidem, p. 254.

${ }^{85}$ Idem Ibidem, p. 254

${ }^{86}$ Idem Ibidem, p. 262.

${ }^{87}$ Idem Ibidem, p. 243.
} 
Também não é surpresa que Romero concordasse com a linha interpretativa de Euclides da Cunha sobre o acontecido em Canudos, já que, como vimos, os dois partilhavam das mesmas convicções nas teorias evolucionistas da época. A aprovação de Silvio Romero ao trabalho de Euclides da Cunha é também uma evidência que contraria a hipótese de que Euclides da Cunha foi um positivista convicto, uma vez que, repudiando o positivismo como Silvio Romero repudiava, é pouco provável que ele aprovasse o trabalho produzido por um escritor que pertencesse a essa escola. A crítica favorável de Romero ao livro de Euclides demonstra a identidade de pensamento entre os dois, pelo menos no que se refere ao ocorrido em Canudos.

Portanto, considero que um dos motivos do livro de Euclides ter sido valorizado por estes críticos é seu caráter científico, acadêmico, e não apenas literário. Deve-se ressaltar, no entanto, que, conforme aponta Venâncio Filho, o uso em excesso de termos científicos e de uma linguagem muito prolixa também foi alvo de críticas por parte de José Veríssimo ${ }^{88}$, ainda que essas críticas tenham sido feitas em âmbito privado, apenas para o próprio escritor. Venâncio também afirma que a isso, Euclides respondeu:

\begin{abstract}
Num ponto apenas vacilo-o que se refere ao emprego de termos técnicos. Aí, a meu ver, a crítica não foi justa. Sagrados pela ciência e sendo de algum modo, permita-me a expressão, os aristocratas da linguagem, nada justifica o desprezo que lhes votam os homens de letras-sobretudo se considerarmos que o consórcio da ciência e da arte, sob qualquer de seus aspectos, é hoje a tendência mais elevada do pensamento humano. (...) Eu estou convencido que a verdadeira impressão artística exige, fundamentalmente, a noção científica do caso que a desperta- e que, nesse caso, a cometida intervenção de uma tecnografia própria se impõe obrigatoriamente e é justo, desde que se não exagere a ponto de dar um aspecto de compêndio ao livro que se escreve, mesmo porque em tal caso a feição sintética desapareceria e com ela a obra de arte. ${ }^{89}$
\end{abstract}

É, portanto, a partir da publicação de “Os Sertões” que começou a ser consolidada a imagem de Euclides como grande escritor de literatura enriquecida pelo conhecimento científico, que chegaria ainda com bastante força aos nossos dias. Depois do grande sucesso de críticas e de vendas de “Os Sertões” - em menos de um ano o livro já estava na terceira edição ${ }^{90}$-, o escritor passou a ocupar importantes cargos nos meios acadêmicos da época, como os de membro do Instituto Histórico e Geográfico Brasileiro e da Academia Brasileira de Letras.

\footnotetext{
${ }^{88}$ VENÂNCIO FILHO, Francisco. “Fundamentos Científicos de Os Sertões”. In: Revista Brasileira, Rio de Janeiro: ano 5, n.9, dez. 1945.

${ }^{89}$ Idem. Ibidem, p. 64.

${ }^{90}$ VENTURA, Roberto. Euclides da Cunha: Esboço Biográfico. São Paulo, Cia das Letras, 2003.
} 
Para esta última, o escritor recebeu votos de acadêmicos como o Barão do Rio Branco e Machado de Assis, então presidente da instituição. O discurso de posse do escritor na ABL é também um indício de que essa memória do escritor recebeu contribuições dele mesmo, que fazia questão de não se definir como apenas um literato. Na ocasião, diria Euclides:

Escritor por acidente- eu habituei-me a andar terra a terra, abreviando o espírito à contemplação dos fatos de ordem física adstritos às leis mais simples e gerais; (...) vai-se-me tornando mais e mais difícil esse abranger os caracteres preexcelentes das cousas, buscando-lhes as relações mais altas e formadoras das impressões artísticas, ou das sínteses estéticas. ${ }^{91}$

E mais adiante:

(...) me desviei, sobremodo, dessa literatura de ficções, onde desde cedo se exercita e revigora o nosso subjetivismo ${ }^{92}$.

O autor, nesse mesmo discurso, também fez questão de frisar que, como homem de ciência, sentia dificuldades de ingressar numa casa de homens de letras ${ }^{93}$. A referência a uma postura científica, tanto por parte do próprio autor como por alguns de seus críticos foi, portanto, recorrente desde a publicação de seu primeiro livro. No entanto, ao longo do tempo, essa postura, chamada na época apenas de científica, foi se convertendo, na crítica do autor, em postura positivista.

\subsection{A tragicidade da morte de Euclides: contribuições para a criação do mito}

Como visto, ainda em vida Euclides da Cunha foi um escritor bastante conhecido entre os literatos e entre a população em geral, e teve seu talento de escritor reconhecido por boa parte dos homens letrados daquele período. No entanto, um dos fatores responsáveis pela glorificação e pela transformação de Euclides em mito foi, também, a circunstância trágica de

\footnotetext{
${ }^{91}$ APUD ABREU, Regina. O enigma de Os Sertões. Rio de Janeiro, Rocco, 1988, p.236.

92 Idem Ibidem.

${ }^{93}$ Idem Ibidem.
} 
sua morte, que ocupou muito grande nos jornais da época ${ }^{94}$ e contribuiu para cristalizar a idéia de que o escritor, injustiçado em vida, deveria ser recompensado depois de morto ${ }^{95}$.

A história pessoal de Euclides da Cunha é realmente novelesca, e não é à toa que ela acabou Formatado: Recuo: Primeira linha: 0 virando, até mesmo, enredo de uma minissérie da Rede Globo em princípios da década de 90. Filho de um pequeno fazendeiro, o escritor nasceu na cidade de Cantagalo no ano de 1861. Logo aos três anos, perdeu sua mãe, vítima de tuberculose, e mudou-se de sua cidade natal para a casa de seus tios. A partir daí, o futuro escritor passou a ter uma vida itinerante: circulou, durante sua infância e adolescência, pelas cidades de Teresópolis, Rio de Janeiro, Salvador e São Paulo. Até que, já na época de cursar os preparatórios para ingressar no ensino superior, Euclides voltou ao Rio para cursar o Colégio Aquino, conhecido na época por fornecer uma preparação sólida àqueles que desejavam ingressar no curso de Engenharia ${ }^{96}$.

Foi durante seus tempos de Colégio Aquino, no qual foi matriculado no ano de 1883, que Euclides da Cunha entrou em contato com uma pessoa que lhe influenciaria significativamente no início de sua vida: Benjamin Constant. O conhecido positivista e futuro ministro do primeiro governo republicano brasileiro era, nessa época, professor de matemática, e graças à sua competência enquanto professor e retidão moral enquanto cidadão conquistou a admiração de Euclides e de muitos outros alunos, que viam no professor um modelo a ser seguido ${ }^{97}$. Foi, portanto, nesse ambiente escolar que Euclides entrou em contato, pela primeira vez, com o positivismo.

É certo que o futuro escritor se tornou, já nessa época, um grande entusiasta da, na época, nova religião, a Religião da Humanidade. Esse contato de Euclides com o positivismo seria aprofundado ainda mais quando da entrada do jovem, em 1886, no curso de Engenharia da Escola Militar, situado àquela época na Praia Vermelha. Euclides acabou por optar pela instituição, que além de ser gratuita, pagava um pequeno soldo a seus alunos, o que tornava o estudo mais fácil para pessoas como Euclides da Cunha, que não vinham de famílias mais abastadas. Uma vez dentro da escola, Euclides voltou a ser aluno de Benjamin Constant, que mais uma vez influenciou seus alunos de forma decisiva a respeito de outra questão: o

${ }^{94}$ Cfr. VENTURA, Roberto. Euclides da Cunha: Esboço Biográfico. São Paulo: Cia das Letras, 2003.

${ }^{95}$ VENÂNCIO FILHO, Alberto. O Movimento Euclidianista, In: Ciclo Comemorativo da Publicação de Os Sertões, 2002, Rio de Janeiro, RJ. Disponível em: www.abl.org.br. Acesso em outubro de 2004.

${ }_{97}^{96}$ VENTURA, Roberto. Euclides da Cunha: Esboço Biográfico. São Paulo: Cia das Letras, 2003.

${ }^{97}$ Cfr. Idem. Ibidem. 
republicanismo ${ }^{98}$. Republicano fervoroso, as aulas de Constant foram fundamentais para a conversão de Euclides da Cunha em um republicano engajado. E foi exatamente essa militância de Euclides pela queda da monarquia que lhe causou a expulsão da Escola Militar. O incidente ocorreria durante uma visita do ministro da Guerra, Tomás Coelho, à Escola Militar. Os alunos, insatisfeitos com a falta de reajuste de seus soldos e com o descaso com que a instituição militar era tratada pelo governo monárquico, combinaram uma revolta no dia da visita do ministro, quando todos deveriam lançar ao chão suas baionetas em sinal de protesto.

No entanto, apenas Euclides cumpriu o combinado para o dia da visita, e por isso, acabou sendo expulso, por ato de rebeldia. O que poderia ter sido uma verdadeira desgraça na vida de Euclides, já que o escritor não teria como pagar a Escola Politécnica e, portanto, veria suas chances de se tornar um engenheiro praticamente findadas, acabou transformando-o em um verdadeiro herói republicano. Isso porque, um ano depois, proclamada a república, o ato de rebeldia diante do velho Ministro da Guerra passou a ser considerado pelos proclamadores da república um verdadeiro ato de bravura, e Euclides se tornou símbolo da república recentemente implantada: estudante de uma instituição militar, jovem, idealista e, sobretudo, lutador. Sua vaga na Escola Militar lhe foi restituída, e seu soldo, como desejado, foi aumentado. Além disso, o aluno foi chamado a conversar pessoalmente com o Major Sólon Ribeiro, também um dos proclamadores da república e alto funcionário do novo governo brasileiro. Na ocasião, Euclides pôde mostrar que havia, de fato, aprendido com seu mestre, Benjamin Constant, a ter uma conduta moral exemplar. Para os proclamadores da república, a bravura do ato de Euclides da Cunha merecia uma premiação maior do que apenas a restituição de sua vaga na Escola Militar: foi oferecida ao jovem estudante, por intermédio de Solón Ribeiro, a oportunidade de ocupar o posto que ele desejasse, ainda que isto estivesse em desacordo com as normas militares. No entanto, Euclides da Cunha recusou a oferta, respondendo que desejava apenas a sua lotação no posto previsto para os engenheiros recémsaídos da Escola Militar ${ }^{99}$. Anos mais tarde, segundo Venâncio Filho, Euclides comentou o ocorrido, em carta endereçada a Lúcio de Mendonça ${ }^{100}$ :

\footnotetext{
${ }^{98}$ Idem Ibidem.

${ }^{99}$ Idem Ibidem.

${ }^{100}$ VENÂNCIO FILHO, Francisco. A Glória de Euclides da Cunha. São Paulo, Companhia Editora Nacional, 1940, p. 20.
} 
O grande doador de posições referindo-se à minha recente formatura e ao meu entusiasmo pela República, declarou-me que tendo eu direito a escolher por mim mesmo uma posição, não se julgava competente para indicá-la.

Que perspectiva. Basta dizer-lhe que estávamos em pleno despencar de governadores estaduais...

E eu (nesta época estava sob o domínio cativante de Augusto Comte, e que isto vá como recurso absolutório) - declarei-lhe ingenuamente que desejava o que previa a lei para os engenheiros recém-formados- um ano de prática na E.F. C do Brasil. Não lhe conto o resto. Quando me despedi pareceu-me que no olhar mortiço do interlocutor estava escrito: "não vales nada".

Foi durante esse encontro que Euclides conheceu Anna Ribeiro, filha de Sólon Ribeiro e sua futura esposa. Depois desse primeiro encontro, o escritor e a menina começaram a namorar e se casaram logo em seguida. Mas os problemas da vida conjugal dos dois não tardariam a começar. Desiludido com a carreira militar e pretendendo exercer a profissão de engenheiro como civil, Euclides enfrentou a desaprovação da esposa e de seu pai, quando anunciou que pretendia deixar a carreira militar. Anna Ribeiro, filha de um militar ilustre, acreditava que a estabilidade e o status conferido pela carreira militar eram motivos suficientes para que o marido permanecesse na instituição. Mas Euclides não pensava da mesma forma, e, mesmo à revelia de sua mulher e de seu sogro, decidiu-se por deixar o exército ${ }^{101}$.

A partir daí, Euclides voltou a ter a vida itinerante que havia tido em sua infância. Sem emprego fixo, o escritor se viu obrigado a viajar em busca de empregos como engenheiro civil, o que encontrou primeiro em Minas Gerais, e depois, em São Paulo. Nesta última cidade, Euclides também passou a exercer a função de jornalista para o jornal de Júlio de Mesquita, O Estado de São Paulo. Foi como cronista do citado jornal que Euclides da Cunha teve a oportunidade de cobrir a Guerra de Canudos in loco. ${ }^{102}$ Depois de escrever um artigo para o jornal, intitulado “A Nossa Vendéia” ${ }^{103}$, em que o autor comparava o que ele via como um bando de fanáticos guiados por Conselheiro à revolta camponesa contra a Revolução Francesa ocorrida na cidade de Vendéia, o escritor foi convidado a acompanhar de perto o conflito. Esse seria um evento marcante na vida de Euclides. Não apenas porque seria esse o tema de seu grande livro, mas também porque suas convicções sairiam bastante abaladas pelo

\footnotetext{
${ }^{101}$ VENTURA, Roberto. Euclides da Cunha: Esboço Biográfico. São Paulo: Cia das Letras, 2003.

${ }^{102}$ Idem Ibidem.

${ }^{103}$ CUNHA, Euclides. A Nossa Vendéia. Disponível em: http://pt.wikisource.org/wiki/A_nossa_vend\%C3\%A9ia_(1). Acesso em: Agosto/ 2009.
} 
desfecho da guerra ${ }^{104}$. Em seu trajeto de ida para o local do conflito, Euclides acreditava, tal como já foi dito e é possível detectar em seu caderno de anotações, segundo Costa Lima ${ }^{105}$, que iria cobrir uma guerra que já tinha um vencedor pré-definido: o exército republicano. Ainda segundo Costa Lima, por ser militar de formação, republicano e conhecedor da doutrina evolucionista, é compreensível que Euclides pensasse dessa forma. Sua certeza acerca da vitória dos republicanos era, até então, inabalável, afinal, não seria possível que os representantes da civilização e do progresso fossem derrotados por sertanejos incultos, por rudes patrícios, nas palavras do próprio escritor ${ }^{106}$. Para Euclides, não era preciso que o conflito terminasse para que fosse possível determinar quem seria o vencedor. As leis da ciência, infalíveis para Euclides, e a perspectiva evolutiva e ascendente que presidiria a história da humanidade eram, para o escritor, indícios suficientes de que o exército republicano seria o grande vencedor desse conflito ${ }^{107}$.

As teses evolucionistas que informavam o pensamento de Euclides contribuíram de maneira considerável para que ele tivesse essa certeza: de acordo com esse conhecimento, o esmagamento dos mais fracos pelos mais fortes faz parte das leis da natureza e precisa acontecer para que a humanidade continue em sua marcha evolutiva. É a seleção natural. Era nesses termos que pensava Euclides da Cunha, e é por isso que, ao chegar ao local do conflito e perceber as dificuldades enfrentadas pelo exército nacional, o autor, inevitavelmente, precisou rever seus conceitos. Afinal, deveria haver uma explicação científica para aquele fenômeno que provavelmente pareceria extremamente ilógico aos olhos dele. Como seria possível um exército improvisado, de esfarrapados analfabetos e incultos vencer o grande exército nacional, treinado pela escola francesa, expressão maior da civilização, em três expedições? Foi, basicamente, essa pergunta, aparentemente sem resposta, que levou o escritor a reconsiderar alguns de seus julgamentos apressados a respeito dos sertanejos ${ }^{108}$. Euclides, sempre utilizando seu cabedal científico, que legitimava suas afirmações, chegou à conclusão de que o sertanejo não era um degenerado, mas um retrógrado, que não precisava de soldados, mas de mestres-escolas. Seria preciso levar a civilização ao interior do país, juntar os dois Brasis tão diferentes e acertar os ponteiros do sertão em relação ao litoral, que

\footnotetext{
${ }^{104}$ Cfr. LIMA, Luiz Costa. Euclides da Cunha: Contrastes e confrontos do Brasil. Rio de Janeiro: Contraponto. NUSEG, 2000.

${ }^{105}$ Idem Ibidem.

${ }^{106}$ Idem. Ibidem.

${ }^{107}$ Idem Ibidem.
} 
segundo ele, estava em um estágio evolutivo mais adiantado do que o interior. Desse modo, o tom da narrativa de Euclides da Cunha muda bastante entre a redação de seu "Diário de uma Expedição e a de Os Sertões.” 109

No entanto, Euclides não abandonou suas convicções evolucionistas e sua fé na ciência. As mesmas teorias científicas que serviram de embasamento para a desqualificação do sertanejo foram utilizadas por Euclides para redimi-los. Desse modo, o escritor utilizou igualmente o conceito de seleção natural para afirmar que, no ambiente onde ocorrera a Guerra de Canudos, o sertanejo era o ser mais adaptado e, portanto, fatalmente ganharia a guerra. Sua fé na ciência saiu de Canudos ainda mais consolidada ${ }^{110}$. Depois da cobertura desse conflito e da publicação, anos mais tarde, de seu grande livro “Os Sertões”, Euclides, como já foi dito, ganhou notoriedade, e por isso suas viagens passaram a ser mais freqüentes. O escritor, graças a recomendações de amigos influentes, recebeu um convite para trabalhar como adido no Ministério das Relações Exteriores, chefiado, naquele momento, pelo Barão do Rio Branco. Incumbido de cartografar e delimitar as áreas recém-conquistadas pelo próprio Barão em contendas com países vizinhos, Euclides viajou para o Acre e para a Amazônia, deixando sua família sozinha. ${ }^{111}$

Sentindo-se sozinha, a esposa de Euclides, Anna Ribeiro, resolveu se mudar para uma pensão onde moravam suas comadres, e lá conhece o sobrinho de uma delas, o cadete do exército, de apenas 17 anos, Dilermando de Assis ${ }^{112}$. Os dois se apaixonaram e iniciaram um romance, camuflado pela amizade do menino com o filho mais velho do casal, Sólon. Três anos mais tarde, já desconfiado e tendo recebido uma carta anônima, Euclides da Cunha, que já havia voltado para a capital federal e há um mês ocupava o cargo de professor de Lógica do Ginásio Nacional, antigo Pedro II, foi a casa de Dilermando para matá-lo, mas acabou sendo assassinado pelo rival, que era campeão de tiro do exército.

A história virou um verdadeiro escândalo nacional. O grande escritor Euclides da Cunha assassinado pelo amante da mulher, mais de 20 anos mais jovem do que ele, parecia

\footnotetext{
${ }^{108}$ Cfr. LIMA, Luiz Costa. Euclides da Cunha: Contrastes e confrontos do Brasil. Rio de Janeiro: Contraponto/ NUSEG, 2000.

${ }^{109}$ Idem Ibidem.

${ }^{110}$ CUNHA, Euclides. Obra Completa. Rio de Janeiro. Nova Aguillar, 1966.

${ }^{111}$ Cfr. VENTURA, Roberto. Euclides da Cunha: Esboço Biográfico. São Paulo: Cia das Letras, 2003.

${ }^{112}$ Idem Ibidem.
} 
inacreditável para a sociedade brasileira de $1900^{113}$. Adultérios femininos eram tão censuráveis que a própria constituição da época permitia que, em defesa da honra, um marido matasse sua esposa infiel ${ }^{114}$. Esse dispositivo constitucional chegou a ser criticado por homens atentos às questões de sua época, como Lima Barreto, que escreveu algumas crônicas criticando essa lei ${ }^{115}$. No entanto, para o senso comum permanecia a idéia de que o adultério, ainda mais vindo de uma mulher, era crime imperdoável. Euclides havia sido vítima desse crime e, mais do que isso, tinha sido assassinado quando tentava lavar a sua honra e a dos seus filhos. Era um crime escandaloso e inaceitável para os padrões da época.

\subsection{O Grêmio Euclides da Cunha do Rio de Janeiro e o positivismo na construção da memória euclidiana.}

Nessa direção, a consagração de Os Sertões na
virada do século pela "nova e moderna crítica
literária representou apenas o passo inicial de
um longo processo. Após a morte do escritor, o
movimento euclidiano iria desempenhar
importante papel nessa seqüência, mantendo ao
longo do tempo a atualidade desse "clássico" e
do pensamento do escritor. ${ }^{116}$

Munidos desse sentimento de revolta, agravado ainda mais quando Dilermando de Assis, defendido pelo famoso advogado Evaristo de Moraes, foi absolvido, os antigos alunos de Euclides no Ginásio Nacional, hoje novamente conhecido como Colégio Pedro II, entre eles os irmãos Sussekind de Mendonça, filhos de um dos fundadores da ABL, fundaram o Grêmio Euclides da Cunha ${ }^{117}$. A intenção inicial do Grêmio, criado em 1911 nas dependências do colégio, era protestar contra a morte estúpida do escritor e não deixar que sua obra caísse em esquecimento. Daí o lema do grupo "Por Protesto e Adoração", criado por Alberto Rangel, um dos grandes amigos de Euclides, que foi eleito presidente de honra da agremiação ${ }^{118}$.

\footnotetext{
${ }^{113}$ Idem Ibidem.

${ }^{114}$.Idem Ibidem.

${ }^{115}$ Cfr. BARBOSA, Francisco de Assis. A Vida de Lima Barreto. Rio de Janeiro: José Olympio Editora, 2003.

${ }^{116}$ ABREU, Regina. O enigma de Os Sertões. Rio de Janeiro, Rocco, 1988, p. 304.

${ }^{117}$ VENÂNCIO FILHO, Alberto. O Movimento Euclidianista, In: Ciclo Comemorativo da Publicação de Os Sertões, 2002, Rio de Janeiro, RJ. Disponível em: www.abl.org.br. Acesso em outubro de 2004, p. 2.
} 
Alberto Venâncio Filho, filho de um dos mais importantes euclidianos desse período, em conferência sobre o centenário da publicação de “Os Sertões”, em 2002, afirmou que ${ }^{119}$ :

O grupo de estudantes deixa o Ginásio Nacional e resolve dar cunho nacional ao Movimento, chamando para presidente honorário Alberto Rangel, o grande amigo de Euclides, companheiro da Escola Militar, cujo livro Inferno Verde foi por ele prefaciado. Alberto Rangel iniciou formalmente as atividades do Grêmio em 15 de Agosto de 1913, na sepultura 3026 do Cemitério São João Batista, onde ficaram os restos mortais de Euclides até serem trasladados para São José do Rio Pardo.

A partir do ano de 1913, os alunos, todos os 15 de agosto, data da morte do escritor, passaram a caminhar até o mausoléu onde estava enterrado Euclides e, sempre acompanhados de personalidades da época, como Coelho Netto, Afrânio Peixoto, José Lins do Rego, entre outros $^{120}$, fazer discursos em homenagem à memória do escritor. Além disso, os alunos promoviam palestras em homenagem a Euclides, sempre no seu aniversário de falecimento. Para proferir as palestras, eram convidados grandes escritores que haviam conhecido pessoalmente Euclides da Cunha. No ano de 1915, foi publicada a primeira revista do Grêmio Euclides da Cunha, em que foram reproduzidos os discursos proferidos à beira do túmulo do escritor e na Academia Brasileira de Letras ${ }^{121}$.

Já nesses discursos iniciais o tom era de adoração mais do que de admiração ou protesto, o que indica o processo de glorificação de Euclides que já começava a tomar forma. Assim, no ano de 1913, Alberto Rangel, companheiro de escola militar do escritor, comparou a trajetória de Euclides à de um santo, que passou por todo o tipo de provações em vida sem nunca perder a firmeza e morrera em defesa de sua honra ${ }^{122}$. Como tal, para Rangel e os estudantes participantes do Grêmio, Euclides da Cunha deveria ser reverenciado e adorado pelos seus seguidores. Será esse o tom que prevalecerá no Grêmio a partir de então.

Venâncio Filho, em trabalho previamente mencionado, cita um trecho do discurso de Alberto Rangel à beira do túmulo de Euclides ${ }^{123}$ :

\footnotetext{
${ }^{118}$ Idem Ibidem.

${ }^{119}$ VENÂNCIO FILHO, Alberto. O Movimento Euclidianista, In: Ciclo Comemorativo da Publicação de Os Sertões, 2002, Rio de Janeiro. Disponível em: www.abl.org.br. Acesso em outubro de 2004, p. 3.

${ }^{120}$ Idem Ibidem.

${ }^{121}$ Idem Ibidem.

${ }^{122}$ Revista do Grêmio Euclydes da Cunha, Rio de Janeiro, ago 1919.
} 
Quisestes acreditar nas forças do bem, da razão e da justiça. Afogados no tranquibérnio de uma nação espasmada no vício, na mediocridade e no esquecimento, a vossa juventude e a vossa crença reclamavam um consolo e um punhado de PROTESTOS. Na vossa ADORAÇÃO não afiançais somente uma supervivência. Aproximastes-vos deste túmulo com a cega piedade de peregrinos de Meca e a sede ardente de reclamantes por uma reparação necessária e infalível. (grifos meus)

Mais adiante, Rangel complementa o seu discurso com palavras esclarecedoras ${ }^{124}$ :

\begin{abstract}
A vossa dedicação cultual aproxima-se, com resolução e entusiasmo, de um santo e de uma vítima. Tendes um sonho religioso. Grande foi o que dorme aqui. Tem ele a força de apurar estas saudades, despertando ainda a fé concentrada em tantos corações, atados pela magia de um estilo, absorvidos de uma idéia, em tantas páginas de arte e pensamento puros.
\end{abstract}

Nas palavras de Alberto Rangel, reproduzidas acima, já é possível notar uma grande quantidade de palavras de cunho religioso: peregrinação, adoração, santo, fé. Essas são apenas algumas das palavras que foram utilizadas pelos euclidianos, que é como os participantes do Grêmio eram chamados, para se referir a Euclides, e que demonstram a sua intenção de não apenas relembrar o escritor, mas de canonizá-lo, de transformá-lo em um santo ou vulto da humanidade, assim como os positivistas faziam com os grandes cientistas e personalidades por eles homenageadas. Para os euclidianos integrantes do Grêmio, a suposta santidade de Euclides da Cunha era fruto de sua retidão moral e de sua competência enquanto homem de ciência e literato, e não em razão de ele ter realizado milagres, que é o critério da religião católica para a conversão de uma pessoa em um santo. O discurso de Coelho Netto à beira do túmulo de Euclides, realizado em 1915, demonstra bem os motivos euclidianos para a glorificação de Euclides ${ }^{125}$ :

Coelho Netto assinalava ainda que a sepultura de Euclides havia sido transformada em altar e incitava os presentes a continuar ano após ano a romaria ao escritor no aniversário de sua morte. "Que a romaria hoje se torne uma religião da mocidade. Somos um povo sem cultos- honremos nossos heróis, observando-lhes os exemplos e nenhum outro, mais do que o

\footnotetext{
${ }^{123}$ Idem Ibidem, p. 4

${ }^{124}$ Revista do Grêmio Euclydes da Cunha. Rio de Janeiro, ago 1919, p. 8.

${ }^{125}$ ABREU, Regina. O Enigma de Os Sertões. Rio de Janeiro. Funarte: 1998, p. 301.
} 
vosso patrono, no-los deixou tão belos, porque ele foi grande no gênio, no amor da pátria, na austeridade e no brio.

Considero, assim, que foram critérios similares aos positivistas, estabelecidos por Comte em seu catecismo, os utilizados, conscientemente ou não, pelos euclidianos em seu projeto de santificação de Euclides da Cunha.

Como vimos, ainda no ano de 1915, o Grêmio passou a contar com uma revista anual, que tinha em seu início o discurso transcrito acima, de Alberto Rangel, nomeado de Oração Inicial. As revistas eram publicadas sempre no dia que marcava o aniversário de falecimento do escritor, e, nesses anos iniciais, apenas continham a transcrição dos discursos proferidos, as palestras realizadas e das atas de reunião dos agremiados.

A utilização do termo Oração Inicial é mais um dos inúmeros indícios que fundamentam a hipótese da similaridade entre os rituais do Grêmio e os positivistas, que será retomada adiante. A revista também incluía as transcrições das palestras que passaram a ocorrer na Biblioteca Nacional, todo dia 15 de agosto, data da morte do escritor.

Além dessas medidas iniciais tomadas pelos agremiados, como a organização de romarias ao túmulo, palestras e da Revista do Grêmio, a publicação da quinta edição de “Os Sertões”, com modificações feitas pelo próprio Euclides antes de morrer, também se deveu ao trabalho de um euclidiano ${ }^{126}$ :

Em 1914, o euclidiano Afrânio Peixoto encarregou-se de produzir a quinta edição de Os Sertões, seguindo as instruções deixadas pelo próprio Euclides em exemplar encontrado no arquivo do autor com a seguinte observação: 'livro que deve servir para a edição definitiva'. Peixoto era na ocasião diretor da Francisco Alves, a editora que adquiriu os direitos autorais de Os Sertões após um incêndio ocorrido na Laemmert, no mesmo ano da morte do escritor. Após as três edições publicadas pela Laemmert, de 1902 a 1909, num total de 11.000 exemplares, a Francisco Alves havia publicado a quarta edição em 1911. A quinta edição da obra vinha com o selo da autenticidade, expressando o último desejo do escritor com relação a seu próprio trabalho.

Os euclidianos também adquiriram, utilizando recursos próprios, uma lápide de mármore que foi colocada no túmulo de Euclides da Cunha. Sobre isso, afirma Alberto Rangel: ${ }^{127}$

\footnotetext{
${ }^{126}$ Idem Ibidem, p. 311.

${ }^{127}$ RANGEL, Alberto. In: Revista do Grêmio Euclydes da Cunha. Rio de Janeiro, ago 1919, p. 11.
} 
Esse mármore será da transparência das talagarças. Ele deixará ver na fina e branca contextura de uma porta de pedra, para sempre fixa nos batentes eternos de um sepulcro, os sacrifícios, os protestos e a dedicação de alguns jovens ante o infortúnio e a glória de um escritor, patriota e viril, traído em vida, subtraído quando morto ao peito de uma sociedade dispersa e asenzalada, que vive a palmear fantoches, a idolatrar farsistas e a coroar bandidos.

Além de todas as medidas citadas, um dos objetivos principais do grupo, nesses anos iniciais, era construir uma estátua de bronze em homenagem a Euclides, que acabou não sendo feita. Para isso, os integrantes do Grêmio começaram a organizar e a promover uma série de eventos pagos, em que euclidianos como Roquette-Pinto e Alberto Rangel faziam palestras e doavam a quantia arrecadada com o evento ao Grêmio. A intenção dos gremistas era a de construir com recursos próprios a estátua de bronze do escritor, que ficaria localizada na Praia Vermelha, local onde havia sido formado o pensamento euclidiano, de acordo com os integrantes do Grêmio ${ }^{128}$. Essa percepção, dos euclidianos, de que foi na Praia Vermelha, local onde se situa a Escola Militar, que foi formado o pensamento de Euclides da Cunha demonstra o destaque dado por eles à fase positivista do escritor.

Além das palestras, os euclidianos esperavam arrecadar dinheiro publicando textos de Euclides da Cunha até então desconhecidos para o grande público, como a palestra "Castro Alves e o seu tempo”, proferida pelo escritor em1907. Foi esse objetivo de arrecadar dinheiro para a construção de uma estátua em homenagem ao escritor que levou os euclidianos a entrar em contato, pela primeira vez, com um outro público de admiradores de Euclides da Cunha: os paulistas, da capital e do interior. De acordo com Regina Abreu, a palestra proferida por Roquette-Pinto em São Paulo, em 1918, cujo título foi “Euclides da Cunha Naturalista”, trouxe como conseqüências, além do aumento dos rendimentos do Grêmio, a adesão de um grupo de paulistas à iniciativa do Grêmio Euclides da Cunha. Nas palavras da autora ${ }^{129}$ :

Em 1918, o movimento euclidiano ganhou novos e importantes adeptos: intelectuais paulistas. (...) Motivados pela conferência, diversos intelectuais aderiram ao movimento euclidiano, entre os quais Alfredo Pujol, Nestor Pestana, Adalgizo Pereira, Veiga Miranda, Amadeu Amaral, Pinheiro Junior. Os euclidianos decidiram na ocasião proclamar as duas cidades, Rio de Janeiro e São Paulo, 'cidades-irmãs' no culto ao escritor.

\footnotetext{
${ }^{128}$ Idem Ibidem.
} 
Mais adiante, Regina Abreu reitera essa adesão ${ }^{130}$ :

Em 1921, diversos intelectuais paulistas assinaram moção de apoio ao trabalho do Grêmio Euclides da Cunha, entre eles, Vicente de Carvalho, Francisco Escobar, Amadeu Amaral, Affonso d'E. Taunay, Plínio Barreto, Júlio de Mesquita, Júlio de Mesquita Filho, Antônio Mendonça, Monteiro Lobato, Otaviano Vieira (esposo da irmã de Euclides), Nestor Rangel Pestana, Alberto Souza, Henrique Coelho, Arthur Motta. Lá estavam, portanto, os diretores de O Estado de São Paulo, um parente, escritores e intelectuais.

O tema da construção da estátua de bronze, que levou os euclidianos a estender suas ações até a cidade de São Paulo, é recorrente nos textos produzidos pelos euclidianos nesses anos iniciais do grêmio, como é possível perceber nos trechos abaixo ${ }^{131}$ :

Que espera o Brasil para imprimir na pedranceira da Praia Vermelha, os traços do homem de talento e coração, que ao lado desse granito titânico formou o seu gênio e incubou o seu ideal republicano e patriota?

O apoio a essa consagração é geral do país, tanto quanto uma idéia pura de objeto venerativo pode congraçar sufrágios, quando as paixões dividem e sobressaltam os embaraços econômicos (...)

Como quer que seja, o altar está erguido, mas o nicho vazio... E não há concorrência de políticos a pretenderem esta glória- o cunho de uma face no lombo de uma rocha.

Paris, 10 de Julho de 1914.

Esse outro trecho, de 1916, insiste no mesmo tema ${ }^{132}$ :

\begin{abstract}
Chegará efetivamente a hora da realização religiosa desse monumento simples, incisivo e perene, intentado à gloria de Euclides da Cunha? Não se quebrará ao contrário o empenho do Grêmio ao pé da indiferença pública, como uma vaga nostálgica aos mexilhões do Recife?

Não importa. Os moços irão exaltando os seus votos e enquanto a fé vingar no bom terreno da esperança há de lhe dar algumas flores para os dias de solenização da Saudade admirativa e protestatória a que servem. Com elas o túmulo de Euclides da Cunha não perecerá a barreira comum e irregressível onde os mortos efetivamente deixam de existir, mas algum sarçal de fogo onde a Imortalidade há de jorrar na sua ascendência radiosa, consolativa e fecunda...
\end{abstract}

Nesse trecho, de 1918, mais uma vez a insistência no tema ${ }^{133}$ :

\footnotetext{
${ }^{129}$ ABREU, Regina. O Enigma de Os Sertões. Rio de Janeiro. Funarte: 1998, p. 309.

${ }^{130}$ Idem Ibidem, p. 310.

${ }^{131}$ RANGEL, Alberto. In: Revista do Grêmio Euclydes da Cunha. Rio de Janeiro, ago 1919, p. 9.
} 
O Grêmio Euclides da Cunha renova a sua vigília anual à cabeceira da tumba do assassinado há nove anos. Enquanto a rocha ou o bronze suplicados não se erigem nas penhas grandiosas da Praia Vermelha, falando da saudade da vítima e da glória do escritor, consagram-nas essas páginas de firme, inteligente e carinhosa comemoração.

O dia do Euclides! No calendário de valia dos favoritos do pundonor e da honra, do talento e da independência, esse se marca com a cruz dos grandes mártires amados...

No ano de 1919, A Revista do Grêmio Euclides da Cunha publicou, ao final de suas páginas, uma nota de esclarecimento, em que seus dirigentes explicavam porque o monumento de Euclides da Cunha ainda não havia sido erguido na Praia Vermelha. Nesse esclarecimento, são narradas as atividades do Grêmio, o nome de alguns associados e colaboradores, o plano de campanha estabelecido por eles em 1917 e os motivos pelos quais, para os euclidianos, Euclides da Cunha era merecedor de tamanha adoração. Segue abaixo a citada explicação ${ }^{134}$ :

\section{“15 de Agosto de 1919}

Marcamos para hoje, repetidamente, a inauguração do monumento que se define como termo nesta campanha, em prol da memória de Euclides da Cunha. Fizemo-lo, conscientes do que queríamos, senhores dos empecilhos a vencer e a dominar. Mas quando o fizemos não adquirira o monumento da babilônia proporções em que o imaginamos agora, e se o quiséssemos como então era, a 15 de Agosto de 1919, o Brasil completaria a efígie simbólica de Euclides, fixada em arte e bronze. Na encosta da mesma montanha, a menor altura e menor dimensão. E como ele só pode e só deve aparecer à admiração e à glorificação do Brasil, à altura magnífica em que hoje o vemos, preferimos lutar mais, lutar muito, até que o consigamos, dentro das linhas rigorosas, em que transcorreu a sua vida.

Se bem que raros tenham direito a que se lhe pague, em glorificação, o que não lhe deram senão mal, em vida, temos o dever de tentar o culto perpétuo da sua memória por outros meios e só após o desânimo definitivo, provado que não deixa esperanças de outro caminho, então poderemos exigir do Brasil, que se lembre de quem lhe deu tanta glória e tanta fama e tão pouco foi retribuído.

Por isso organizamos o nosso largo plano desenvolvido pelas duas diretrizes principais: a)--- publicações de trabalhos inéditos ou não de Euclides ou a que a ele refiram; b)—a realização de conferências sobre aspectos euclidianos.

Com as dimensões de 6 metros próximos, a altitude de 120 são as em que a arte magnífica de Corrêa Lima planeou o nosso monumento, certo o custo a que o elevou correspondeu à necessidade de maiores recursos.

\footnotetext{
${ }^{132}$ Idem Ibidem, p.15.

${ }^{133}$ Idem Ibidem, p.17.

${ }^{134}$ Idem Ibidem, p.27-30.
} 
Poderíamos aqui encerrar essas justificativas.

A sinceridade do nosso culto, a constância com que o vimos mantendo, o desinteresse que se desafia, eram sobras para que não receássemos a mais leve suspeita injuriosa; e entre outros nomes que o constituem, alguns obscuros e modestos, o Grêmio Euclides da Cunha conta hoje como sócios efetivos, companheiros de toda a hora, um professor da Escola Naval, outro da politécnica, dos mais distintos ambos e têm a confiança de Mestres, que seriam seus fiadores: Alberto Rangel, Roquette-Pinto, Afrânio Peixoto, Basílio de Magalhães, Vicente de Carvalho, Pacheco Leão, Ignácio Amaral, Otaviano Vieira, Escragnolle Doria, Affonso Taunay, Coelho Netto, entre outros.

Mas se nada permite suspeita, em sinceridade e lisura, pode haver talvez os que suponham arroubos apenas de mocidade, empresa de tamanho porte. Pode ser também que nos atribuam visualidade estonteada de fanáticos ou culto exagerado de fetichistas, mas fetichismo ou fanatismo, tem-nos permitido, pelo carinho de um e pelo ardor de outro, ir buscando, aqui e ali, traços e documentos de sua vida, que mais nos aumentam e consolidam essa grande adoração.

Sem o símbolo de patriotismo que Euclides da Cunha, como nenhum outro pode representar, há na contemplação do Homem, na apreciação da obra, os motivos causais dominantes do 'protesto e adoração'.

Não é ele apenas dono de vocabulário rico, que seja mérito a esconder hipocrisias de idéias, como a refletir hipocrisias da vida; probo, só usava da palavra para fins de expressão, que lhe correspondesse à idéia solida e acabada que tinha sempre justa e precisa: artista e cientista, não o foi apenas pelo dom de favorecido; se o teve, mereceu-o porque o apurou pelo estudo, pelo esforço, pelo trabalho; cercado das vicissitudes mais pesadas e amargas, manteve a linha reta indeformável de uma conduta, só sem inveja, sem maledicência., generoso e bom, íntegro até a última hora, que foi de horror e honra.

É por tudo isso, embevecidamente contemplado, conscientemente apreciado, que não se deforma a todas as ações de um meio, quiçá adverso, o nosso culto por Euclides da Cunha.

Vejamos agora o nosso caminho percorrido e fixemos os marcos que teremos de seguir até o monumento da babilônia.

As primeiras contribuições que nos chegaram, como da câmara municipal de Cantagalo, da conferência de Alberto Rangel, apenas deram para cobrir de um mármore modesto à sepultura 3026 do São João Batista.

Só em 1916 o nosso programa foi riscado com linhas definidas, que se devem a Alberto Rangel, como a ele se deveram, desde 15 de Agosto de 1913, as primeiras palavras à memória de Euclides da Cunha.

Até 1917 o Grêmio limitou a sua ação à organização do seu plano de campanha e às comemorações anuais, feitas, como até agora, da só contribuição dos seus sócios, constantes da publicação da Revista e romaria ao túmulo-altar. Em 1917 começamos a preparar a edição do 'Castro Alves e o seu tempo', conferência feita em 1907 por Euclides, em São Paulo, cuja edição se achava esgotada. Fizemo-la, com o mais carinhoso cuidado. Imagináramos a possibilidade de uma larga venda, atentas de papel, impressão, e preço, com que aparecera o volume.

Infelizmente, até agora nada confirmou a nossa esperança. 
Realizamos a 15 de Agosto de 1917 a conferência em que Roquette-Pinto, com o gosto fino de artista e a visão culta de sábio trouxe a sua contribuição valorosa para a nossa casa. O nome do autor da 'Rondônia' e o interesse pelo assunto, 'Euclides da Cunha naturalista', aumentaram essa contribuição, já de si bastante, dando um rendimento animador. Repetida em São Paulo, pela generosidade deste querido mestre, que é sem medida, conquistou uma unanimidade de aplausos, seja de uma imprensa, que tudo facilita e ajuda, seja de uma assistência que não teve restrições ao grande entusiasmo que sua palavra despertou e deu-nos a confiança de realizar oportunamente uma série de conferências lá; apenas o aumento de despesas que essa realização acarretou fez com que, além da exigüidade do tempo de que dispusemos, não houvesse lucro material. De Abril a Agosto fomos prosseguindo na colheita de dados euclidianos, na expedição do Castro Alves e o seu tempo pra os Estados e preparando a comemoração de 15 de Agosto de 1918.

Apesar de alguma dificuldade, realizamos neste dia a conferência magnífica de Coelho Netto sobre Feições do homem; por exíguo o prazo que dispusemos, o lucro desta conferência não foi o que poderia ter sido, em maior lapso de tempo.

Contratando com a Revista do Brasil, de S. Paulo, tiramos uma separata da conferência do Dr. Roquette Pinto, acrescida de alguns chichês e de um prefácio do Dr. Vicente de Carvalho.

Segue-se a esse esclarecimento um balanço de todas as atividades do Grêmio e dos rendimentos e custos gerados por elas. Entre essas atividades, podemos citar:

As conferências citadas, a edição e publicação de “Castro Alves e o seu tempo”, que foi vendido a preço de \$440 para sócios, em livrarias do Rio de Janeiro, Santos, Recife, Paraná, Maranhão, Amazonas e as revistas publicadas, além das contribuições pagas pelos sócios efetivos. Mesmo assim, concluíram os euclidianos, as receitas conseguidas não foram suficientes para realizar, até o ano de 1919, este objetivo do Grêmio Euclides da Cunha: a confecção de uma estátua em homenagem ao escritor ${ }^{135}$.

Sobre esses objetivos e atividades iniciais do Grêmio, denominados por eles mesmos de plano de campanha, afirma Abreu ${ }^{136}$ :

Com este 'plano de campanha' estava traçado o destino de Euclides da Cunha. Incansáveis, os euclidianos partiriam para meticuloso trabalho de levantamento de fontes, reunião de cartas, documentos e relíquias do

\footnotetext{
${ }^{135}$ Revista do Grêmio Euclydes da Cunha. Rio de Janeiro, ago 1919, p. 30.

${ }^{136}$ ABREU, Regina. O Enigma de Os Sertões. Rio de Janeiro. Funarte: 1998, p. 303.
} 
escritor. Imbuídos da missão de manter viva a chama euclidiana, esses intelectuais agiram como verdadeiros sacerdotes divulgando a palavra do mestre. Nunca antes, no país, um escritor teve tantas pessoas a seu serviço.

Outra característica importante a ser ressaltada nos anos iniciais do Grêmio Euclides da Cunha é a participação ativa que teve nele Alberto Rangel, mesmo que de Paris. Amigo de Euclides desde os tempos da Escola Militar, Alberto Rangel também participou das aulas de Benjamin Constant e teve contato com o positivismo, do qual não parece ter se afastado, tendo em vista a maneira similar ao positivismo com que ele conduziu as homenagens a seu amigo falecido. A relação de Alberto Rangel com o positivismo já foi ressaltada em outros trabalhos, como o de Cynthia Agra de Brito Neves, intitulado "Positivismo e vida militar em Alberto Rangel” ${ }^{137}$. Nos anos iniciais do Grêmio, quando os seus idealizadores eram apenas adolescentes, foi Alberto Rangel que começou a dar ao Grêmio a forma de uma instituição de adoração a Euclides da Cunha similar aos rituais positivistas. Na Revista do Grêmio Euclides da Cunha de 1919, em que foram impressos os discursos feitos em memória do escritor entre os anos de 1914 e 1919, foi o nome de Alberto Rangel o que apareceu com maior constância. O tom de Rangel em seus inúmeros discursos permaneceu o de idolatria e adoração, e Euclides era tratado como um verdadeiro Vulto da Humanidade, ou da brasilidade. Nos anos seguintes do Grêmio, em que o nome de Rangel aparecereu com menos constância e os nomes de Edgard Sussekind de Mendonça, Roquette-Pinto e Venâncio Filho apareceram com muito mais freqüência, o tom de adoração a Euclides nos moldes positivistas permaneceu o mesmo.

Nos trechos selecionados, mais uma vez é possível perceber a idolatria com que Euclides era tratado por Rangel ${ }^{138}$ :

Paris, 10 de Julho de 1914

Sr. Presidente e demais membros do Grêmio Literário Euclides da Cunha,

Tenho a honra de oferecer ao Grêmio uma dúzia de cartas e dois postais a mim dirigidos pelo amigo e mestre de Os Sertões. Ao vosso interesse por tudo quanto fala de tão poderosa mentalidade e a reflete, entrego esses papéis corridos por seus dedos e santificados por seu coração. Na sua intimidade, porém, nada há que lhe diminua o espírito fulgurante e a dolorida sentimentalidade que as ditaram. Não podia ser de outro modo. Homens dessa natureza não têm altos nem baixos, conservando também, no

\footnotetext{
${ }^{137}$ NEVES, Cynthia Agra de Brito. Positivismo e vida militar em Alberto Rangel. 1995. Monografia (graduação). Curso de graduação em Licenciatura em Letras. Universidade Estadual de Campinas, UNICAMP, Brasil.

${ }^{138}$ Revista do Grêmio Euclydes da Cunha. Rio de Janeiro, Ago 1919, p. 9.
} 
obscuro bastidor das relações comuns, a integridade de suas nobres qualidades reais.

Montai também a guarda de admiração e de afeto junto a esses manuscritos. Sois o destacamento de toda uma nação e o qual não se rende, nem adormece na sentinela à querida memória de Euclides da Cunha. Estais a pé firme e assim continuareis no vosso posto. A senha é - Adoração, a contrasenha - Firmeza. Será fácil reconhecer-nos, amigos, na volubilidade, na inconsciência e no esquecimento geral da nossa terra.

Do companheiro grato e atento - Alberto Rangel

Em trecho do discurso proferido em 1919, Rangel manteve o mesmo tom ${ }^{139}$ :

A praça pública pode satisfazer-se com os monumentos, aos sentimentos da verdadeira admiração, isso não basta. Em indivíduos como Euclides da Cunha, sobra alguma coisa do molde do bronze em que se os tente dignificar. Esse resto é tudo. No continuado estudo de sua personalidade, no recolher de suas pobres relíquias, educamos o nosso interesse no desinteresse, a nossa crença nas ressurreições desse mundo, justificamos a imortalidade dos abnegados, dos inteligentes e dos pundonorosos que não foram felizes... E assim a nós mesmos melhoramos, lembrando o martírio e o valor do que caiu ensangüentado e limpo...

Dessa ocupação nos honraremos sempre. Não se dirá que lavra no Brasil exclusivamente a mesquinhez reptiliana de adorar os que vencem na urna, os que engrimpam no poder. O culto euclidiano celebrará a páscoa do pensamento brasileiro, sorguido nos raios do desagravo da dignidade humana.

Nesses últimos trechos destacados, mais uma vez é possível notar a grande quantidade de termos religiosos utilizados pelos euclidianos. Seu túmulo era chamado de túmulo-altar, o cultivo da memória de Euclides, de ressurreição, o culto euclidiano, de páscoa do pensamento brasileiro, “Os Sertões”, de Bíblia da brasilidade, entre muitos outros exemplos.

Quando se referiam a Euclides, os colaboradores da Revista escreviam o $h$ de homem em letra maiúscula, o que demonstra que a proposta do Grêmio havia se tornado, de fato, a de canonizá-lo, mais do que apenas a de guardar a sua memória. Ao longo do texto, à medida que outros trechos de discursos proferidos por euclidianos forem aparecendo, surgirão mais exemplos que evidenciam a similaridade entre a ‘canonização’ de Euclides e aquela feita na

\footnotetext{
${ }^{139}$ Revista do Grêmio Euclydes da Cunha. Rio de Janeiro, Ago 1919, p.6.
} 
Igreja Positivista aos 'Vultos da Humanidade'. Em texto intitulado “Paulo Carneiro e Casa de Augusto Comte”, foi ressaltada essa característica do positivismo ${ }^{140}$ :

Vale realçar também o grau de importância que os positivistas conferiam aos chamados grandes nomes da história, que, sempre venerados, alcançavam áurea de santos, tornando-se imortais para a 'posteridade regenerada', o futuro- a sociedade positiva.

Apesar de não ressaltar a semelhança entre os rituais euclidianos e os positivistas, Regina Abreu também enxerga uma semelhança entre o ritual de culto a Euclides da Cunha criado pelos euclidianos e as celebrações religiosas ${ }^{141}$ :

Com o plano de campanha dos euclidianos, lançado em 1917, Os Sertões era cada vez mais lido como 'um livro de ciência e fé'. Se, por um lado, era incluído como leitura obrigatória para intelectuais de vanguarda, como Roquette-Pinto, por outro, era objeto de culto religioso por parte de seus admiradores. Os Sertões transformava-se em ponto de partida para os estudos considerados sérios no país, ao mesmo tempo em que, como A Bíblia, admitia múltiplas interpretações e aproximações, podia ser lido de várias maneiras, como literatura, como ciência, como tratado de geografia, de história ou de botânica, como um libelo a favor dos bárbaros sertanejos no interior da nacionalidade, e assim por diante.

Alguns documentos, pertencentes ao Arquivo Euclides da Cunha da ABL, demonstram, mais uma vez, o entusiasmo e a seriedade com que o Grêmio Euclides da Cunha era tratado pelos seus maiores colaboradores. O passar dos anos não diminuiu a seriedade e o engajamento dos euclidianos com relação ao Grêmio criado por eles. Na correspondência abaixo, de autoria de Edgard Sussekind de Mendonça e endereçada ao redator do Jornal do Brasil, em 1923, o euclidiano afirmou ${ }^{142}$ :

Nunca se fez mais do que ontem: a romaria ao túmulo, no cemitério de São João Batista, onde falou Roquette Pinto, a publicação da revista anual com inéditos de Euclides e artigos especiais de Alberto Rangel e Afrânio Peixoto, as conferencias à noite de Goulart de Andrade e Viriato Correa, no Centro Paulista, e até a inauguração de um serviço especial de informações $e$ consultas sobre a vida e a obra de Euclides da Cunha, serviço que funcionará todos os sábados, das 4 às 6 horas da tarde, na Rua São José 14, sobrado.

\footnotetext{
${ }^{140}$ FRAIZ, Priscila e REIS, Eduardo Queiroz. Paulo Carneiro e Casa de Augusto Comte. In: Ciência, Política e Relações Internacionais: ensaios sobre Paulo Carneiro. Rio de Janeiro: editora Fiocruz e UNESCO, 2004, p. 78. ${ }^{141}$ ABREU, Regina. O Enigma de Os Sertões. Rio de Janeiro, Funarte; 1988 p. 308.

${ }^{142}$ Arquivo Euclides da Cunha. Série 7 Código de referência: BR ABL AA EC gec. In: Academia Brasileira de Letras.
} 
Qual é o outro intelectual brasileiro, qual é o outro brasileiro, intelectual ou não, que tem isto?

Toda essa militância foi, por vezes, alvo de críticas por parte da imprensa e de outros intelectuais, como nos conta o próprio Alberto Venâncio Filho ${ }^{143}$ :

Em 1920, pelas folhas de um jornal do Rio de Janeiro, um foliculário tentou empanar a atuação do Grêmio, visando principalmente a figura de Francisco Venâncio Filho. Com o advogado Humberto Blasi, o Grêmio e seu diretor foram a juízo, e obtiveram, por sentença de 29 de Março de 1921, a condenação do articulista.

Desse modo, a atuação dos intelectuais já mencionados no Grêmio Euclides da Cunha foi constante e extremamente dedicada. Relembrar, glorificar, popularizar, santificar, e levar Euclides ao posto de maior escritor nacional foi atividade das mais importantes na vida desses euclidianos.

Essa atitude obsessiva e persistente, vinda de um grupo determinado de intelectuais, ligados às chamadas ciências naturais, possibilita a discussão mais aprofundada das hipóteses já lançadas acima, que dizem respeito não só aos motivos que levaram estes intelectuais a eleger Euclides da Cunha como seu objeto de veneração, mas também à relação entre essa atitude e o positivismo atribuído ao autor de "Os Sertões".

Afinal, a forma como Euclides era tratado pelo Grêmio era, reitero, muito similar à forma como eram tratados os Vultos da Humanidade propostos como exemplos pela Religião da Humanidade. Euclides tinha estátuas, oração própria, romarias em sua homenagem, cidade sagrada e até dia santo, o 15 de agosto, em que euclidianos organizavam uma verdadeira romaria em homenagem ao escritor e que chegou inclusive a se tornar feriado na cidade de São José de Rio Pardo, nomeada de “Meca do Euclidianismo” pelos euclidianos do Rio de Janeiro. Na Revista do Grêmio Euclides da Cunha de 1939 aparece o seguinte comentário, acerca do apelido dado à cidade paulista ${ }^{144}$ : "Cada ano que passa S. José do Rio Pardo, justamente apelidada de Meca do Euclidianismo, amplia as suas homenagens ao seu grande Nome" (grifo meu).

\footnotetext{
${ }^{143}$ VENÂNCIO FILHO, Alberto. O Movimento Euclidianista, IN: Ciclo Comemorativo da Publicação de Os Sertões, 2002, Rio de Janeiro. Disponível em: www.abl.org.br. Acesso em outubro de 2004, p. 8.

${ }_{144}^{14}$ S. José do Rio Pardo. In: Revista do Grêmio Euclydes da Cunha. Rio de Janeiro, Ago 1930.
} 
Euclides era tratado explicitamente como santo entre os integrantes do Grêmio. Além disso, os euclidianos conseguiram que a cabana em que Euclides escreveu "Os Sertões" fosse tombada pelo Patrimônio Histórico Nacional, como será explicado no item sobre o Grêmio Euclides da Cunha de São José do Rio Pardo ${ }^{145}$.

Para citar mais um exemplo da atitude dos membros do Grêmio em relação à memória de Euclides, as palavras introdutórias de Venâncio Filho ao livro que, em 1940, publicou sobre o autor, bem como o título da obra, são eloqüentes. O livro inicia-se da seguinte maneira ${ }^{146}$ :

... Por Protesto e Adoração...

... sempre algumas flores, a dia certo, nesta sepultura, por protesto e adoração.

ALBERTO RANGEL

Nenhuma glória foi, no Brasil, maior que a de Euclides da Cunha. Nenhuma também tão cheia de vicissitudes.

Publicado "Os Sertões", como o sabeis, vieram-lhe imediatos os louvores, as consagrações, o prestígio, a fama, em contraste com o seu viver cotidiano, penoso e rude, entre desgostos e amarguras, ignorados $e$ discretos.

Morto, no clarão de escândalo impiedoso de uma tragédia que empalidece às vezes as de Esquilo ou Dante, Shakespeare ou Ibsen, continuou a sua glória no mesmo esplendor, mas no mesmo opróbrio.

Foi a vossa oração, pronunciada no recanto sagrado de campo santo, à beira da sepultura 3.026 de S. João Batista, que iniciou 'o protesto violento e comprovado', na documentação insofismável, e pôs o marco inicial dessa estrada que percorremos nós, vossos discípulos fiéis, neste ciclo de 25 anos, que hoje termina. Não fora a voz que de longe nos chegava, cheia de fé, para aquele dia certo, sempre nova no tanger a mesma corda de saudade e de culto e teríamos parado em meio, senão em início.

Este livro será apenas o raconto deste caminho percorrido e se nele houver o que se possa servir de esperanças e alentos ao Brasil no exemplo deste gênio que era santo, sacrificado por tudo o que nos falta, caberá a vós, Mestre de toda a honra, o que o acaso merecer. Por protesto e adoração. ( grifos meus)

\footnotetext{
${ }^{145}$ APUD ABREU, Regina. O enigma de Os Sertões. Rio de Janeiro, Rocco, 1988, p. 286.

${ }^{146}$ VENANCIO FILHO, Francisco. A Gloria de Euclydes da Cunha. Rio de Janeiro, Companhia Editora Nacional, 1940, p. 11.
} 
Essa introdução, presente no livro “A Glória de Euclides da Cunha”, de Venâncio Filho é apenas mais um dos inúmeros exemplos a respeito do tratamento dado pelos euclidianos a Euclides da Cunha.

De fato, ele era tratado como santo. Mas esse santo, como já foi dito, era inspirado nos padrões positivistas e não nos cristãos, não apenas por que os grandes expoentes do movimento, - Alberto Rangel, e mais tarde Edgard Sussekind de Mendonça, Roquette Pinto e Venâncio Filho - eram positivistas ${ }^{147}$, mas pela própria concepção de exemplaridade proposta pela Igreja Positivista, que parece muito similar à que foi utilizada pelos euclidianos. Isso porque para os positivistas, os vultos proeminentes da humanidade cuja exemplaridade a Igreja reconhecia e cultuava, não eram aqueles grandes benfeitores e exemplos de fé, como propõe a Igreja Católica, mas sim expoentes do campo científico, literário, filosófico e cultural que, além de serem exemplos de boa conduta moral, contribuíram para o progresso da humanidade ${ }^{148}$. Entre os vultos positivistas, que integram o seu calendário, podemos citar: Aristóteles, Arquimedes, Descartes, Dante, Gutenberg e Homero. Todos os citados mereceram a honraria de integrar o panteão positivista por terem contribuído, na ótica dessa filosofia, para a evolução científica e cultural da humanidade. ${ }^{149}$ Pelos textos que publicaram, vemos que o que despertou nesses euclidianos a admiração e até a paixão por Euclides da Cunha foi a sua conduta moral e sua obra, em que ele utilizou o conhecimento científico para realizar e fundamentar a sua interpretação sobre o Brasil. Portanto, no ponto de vista dos euclidianos, Euclides da Cunha contribuiu, com a sua obra, para o progresso da nação, diagnosticando e denunciando a existência de estágios civilizacionais diferentes no litoral e no sertão do país, e propondo a integração dos sertanejos ao estágio evolutivo já alcançado no litoral, por meio da educação. Esse legado deixado por Euclides o credenciaria a ocupar o lugar de maior escritor nacional e o de vulto da brasilidade. ${ }^{150}$

A todo o momento, e em grande parte dos artigos, de positivistas ou não, a capacidade de Euclides de unir literatura e ciência era ressaltada. Logicamente, quando esses artigos eram

\footnotetext{
${ }^{147}$ Os três euclidianos citados aparecem como membros na ata de fundação da Associação Brasileira de Augusto Comte, de 1945.

${ }^{148}$ COSTA, João Cruz, Contribuição a história das idéias no Brasil: o desenvolvimento da filosofia no Brasil e a evolução histórica nacional. Rio de Janeiro J. Olympio, 1956.

149 www.igrejapositivistadobrasil.org.br. Acesso em Outubro/2009.

${ }^{150}$ Revista do Grêmio Euclydes da Cunha. Rio de Janeiro, 1919-1939.
} 
dos citados positivistas, essas qualidades ganhavam um destaque ainda maior. De acordo com Venâncio Filho e Roquette Pinto, respectivamente:

A concepção de escritor que tinha Euclides da Cunha, um tanto antecipada ao nosso tempo, era a de alguém que fundisse a um só tempo ciência e arte, em uma só peça. Tem sido prejuízo da nossa cultura esse predomínio literário ${ }^{151}$

Euclides da Cunha, se ergueu, para a posteridade, o monumento eterno de Os Sertões construiu, ao mesmo tempo, para a terra, a ponte de São José do Rio Pardo. ${ }^{152}$

Desse modo, a escolha pontual de Euclides da Cunha como objeto de veneração parecia estar ligada a outros fatores, além da trágica morte de que ele foi vítima. Considero que Euclides da Cunha representava o símbolo de um escritor e homem de ciência que era para esses intelectuais o modelo ideal de escritor. Portanto, e embora o Grêmio tenha sido criado por alunos inconformados com a morte terrível de seu mestre, havia mais do que um simples inconformismo motivando a sobrevivência do Grêmio ao longo de décadas entre os euclidianos. Havia um projeto a ser sustentado, e esse projeto, pelo menos para as lideranças do Grêmio, os já citados Alberto Rangel, Edgard Sussekind de Mendonça, Venâncio Filho e Roquette-Pinto, incluía a defesa de um tipo específico de literatura: a literatura científica.

O Grêmio foi, ao longo dos anos, ganhando esse caráter de adoração e de culto cívico que se parecem bastante com as solenidades positivistas, como vem sendo afirmado nos últimos parágrafos. Entre essas similaridades, pode-se destacar também o culto à personalidade, dos euclidianos em relação a Euclides e dos positivistas em relação a seus vultos. Como vimos, a veneração de homens que, acredita-se, tiveram uma papel de destaque na história da humanidade, é uma das características marcantes do positivismo, que justifica essa prática com base na idéia de que os vivos são governados pelos mortos.

Nada mais parecido com o que aconteceu com a memória de Euclides. Um trecho retirado da Revista do Grêmio Euclides da Cunha de 1919, de autoria, mais uma vez, de Alberto Rangel,

\footnotetext{
${ }^{151}$ VENÂNCIO FILHO, Francisco. Fundamentos Científicos de Os Sertões. IN Revista Brasileira. Rio de Janeiro: ano 5, n.9, dez. 1945p. 70.

| ${ }^{152}$ ROQUETTE-PINTO, Edgard. Ensaio Sobre Os Sertões IN Revista da Academia Brasileira de Letras, Rio de Janeiro: v.31, n.93, set 1929, p. 82.
}

Formatado: Fonte: 10 pt, Português (Brasil) 
deixa claro a posição dos euclidianos sobre esses rituais de adoração a cientistas e intelectuais já falecidos. No trecho citado, Rangel escreve ${ }^{153}$ :

No dia 27 de Abril passado, realizaram os amigos de Musset, os mussetistas, como aqui são chamados, a sua peregrinação ao tumulo do poeta Pére Lachaise. Eram quatro na tarde. Um grupo de pessoas afrontando a chuva glacial hórrido, trespassante e retardado inverno, desfilou ante o salgueirinho mofino reclamado pela sextilha do epitáfio.

Mês chers amis, quand jê mourrai,

Plantez um saule au cimetiére

Há alguns dias passados escritores e artistas convidavam o público à abertura do pavilhão de Balzac, onde reúnem e expõem as lembranças do gigante modelador da comédia humana.

Na praça dos vosgues aqui em Paris conserva a casa de Victor Hugo (...). $\mathrm{Na}$ rua monsieur Le Prince celebram Auguste Comte, mantendo o apartamento em que o philosophe chamava por Clotilde...

A charmettes acodem os rousseaunianos.

Em Ferney conservam o que pertenceu a Voltaire.

Schiller, Goethe e Beethoven são objetos de romarias...

Euclides da Cunha, pela força do seu talento e da sua desgraça deu-nos o ensejo de aprender os ritos da veneração no culto da saudade e da justiça por sua memória bem amada. (...). As virtudes e o espírito de Euclides nos ensinaram a boa idolatria do seu culto precioso, que abriu uma brecha feliz no muro terrível da indiferença generalizada no nosso revoltante pouco caso pelos vultos que fazem viver o Brasil do pão dormido do seu gênio. Por Euclides da Cunha iniciamos a face de uma cultura que desconhecíamos, a de não deixar completar a morte a sua obra dissolutoria, a de não consentir no aniquilamento a que ela se propõe cavando e enchendo a buraqueira dos cemitérios.

Ainda que se possa argumentar que rituais de culto à personalidade não eram exclusividade dos positivistas, os euclidianos adicionaram a essa prática uma série de outras muito similares à forma como os positivistas tratavam e reverenciavam seus vultos, como o estabelecimento de uma cidade santa, chamada de Meca, da mesma maneira que os positivistas chamam Paris de a Meca do positivismo, o estabelecimento de dias santos, de peregrinações, orações, estátuas e a transformação de “Os Sertões” em um livro e guia sagrado, uma verdadeira Bíblia, como eles mesmos afirmam em vários trechos. Essa ritualística é também bastante similar à da Igreja Católica, pois boa parte dos rituais católicos foi apropriada por Comte em seu “Catecismo Positivista”, como já foi esclarecido no primeiro capítulo. Comte vinha de

\footnotetext{
${ }^{153}$ Revista do Grêmio Euclydes da Cunha. Rio de Janeiro, Ago 1919, p. 4-5.
} 
uma família extremamente católica, e considerava o positivismo posterior, mas herdeiro do catolicismo.

Outra questão que merece ser comentada a respeito da citação acima diz respeito à conservação do apartamento de Auguste Comte em Paris, feita pelos positivistas brasileiros liderados por Paulo Carneiro, que tinha uma relação de proximidade muito grande com os euclidianos citados, como será demonstrado no item seguinte. Carneiro foi aluno de Francisco Venâncio Filho, freqüentou a Livraria Científica fundada por Carlos Sussekind de Mendonça, irmão de Edgard e, durante toda a sua vida, manteve contato com seu mestre e seus amigos euclidianos. Além disso, como bom positivista, teve a sua trajetória profissional marcada pela dedicação à ciência, como Químico e delegado da UNESCO ${ }^{154}$. A semelhança entre os rituais positivista e euclidiano foi ressaltada e reconhecida pelo próprio Paulo Carneiro ${ }^{155}$ :

O culto consagrado à memória de Euclides nas comemorações do 15 de agosto, nas visitas coletivas ao seu túmulo, na evocação de todos os episódios de sua vida através das relíquias conservadas no Museu de São José do Rio Pardo, imprimiu aos sentimentos puramente humanos que o motivaram um caráter religioso de inspiração nitidamente comtiana. Não era, aliás, Euclides, estranho às idéias do grande pensador que se refletem em muitos dos seus escritos e às quais se refere sempre com deferência e apreço. Valha de exemplo uma curta passagem de importante artigo em que definiu no Estado de São Paulo de 29 de março de 1892, a sua posição perante o positivismo:

'Baseada no mais amplo conhecimento do mundo e do homem, consorciando indissoluvelmente a religião e a ciência, nobilitando $e$ amplificando admiravelmente a vida individual pelas generosas expansões do altruísmo, a nova doutrina está talvez destinada, no futuro, após uma maior e mais geral ascensão a todos os espíritos, a simbolizar a maior conquista da consciência humama.'

Em conferência comemorativa do centenário de Euclides, pôs Ivan Lins em evidência as afinidades intelectuais do antigo cadete, discípulo de Benjamim Constant, com o fundador da religião da Humanidade. Talvez tenham sido elas a origem do interesse que, em várias ocasiões, possuía Francisco Venâncio Filho pelo positivismo, levando-o a inscrever-se como membro da Associação Brasileira dos Amigos de Augusto Comte, criada por meu pai, em

1945.

\footnotetext{
${ }^{154}$ MAIO, Marcos Chor. Ciência, Política e Relações Internacionais. Ensaios sobre Paulo Carneiro. Rio de
} Janeiro, editora Fiocruz, 2004. 
Desse modo, não seria possível que as idéias positivistas tivessem influenciado os intelectuais responsáveis não só pela criação, mas por toda a militância que foi capaz de tornar conhecido nacionalmente, entre os anos 30 e 40, o Grêmio Euclides da Cunha? Além disso, não seria possível que a construção de uma imagem sobre Euclides da Cunha em que o escritor aparece como um positivista convicto tivesse contado com a contribuição dos euclidianos, que durante os tempos do auge do Grêmio eram as maiores autoridades no assunto? ${ }^{156}$ No trecho destacado acima, Paulo Carneiro faz questão de associar Euclides e o positivismo, fundamentando seu argumento com uma fala do escritor do ano de 1892, quando ele ainda era um engenheiro novato recém-saído da Escola Militar e ligado aos ideais positivistas. No entanto, o Euclides que publicou “Os Sertões”, dez anos mais tarde, e que provocou tanta admiração nos euclidianos, já não dava mais tantas declarações entusiasmadas sobre o positivismo $^{157}$. É como se esse primeiro momento do pensamento euclidiano, em que ele demonstrava entusiasmo pela teoria de Comte, fosse ressaltado pelos euclidianos e também pelos positivistas, ao mesmo tempo em que sua identidade com outras correntes científicas eram menos comentadas, criando a impressão de que apenas o positivismo havia influenciado o escritor, ou de que o positivismo foi a corrente de pensamento mais relevante para Euclides da Cunha.

Também não se pretende afirmar que os euclidianos tenham negado a influência do evolucionismo em Euclides da Cunha. Essa influência foi mencionada por eles algumas vezes, ainda que, na maioria das vezes, eles silenciassem ou preferissem ressaltar outros traços da obra do escritor. O trecho a seguir, retirado da obra de Venâncio Filho, intitulada “A Glória de Euclides da Cunha” ${ }^{158}$, já mencionada, é um dos poucos exemplos em que os euclidianos mencionam o interesse de Euclides da Cunha por Comte, mas também Spencer:

Na Revista da família acadêmica, a colaboração euclidiana é freqüente, mas principalmente em versos, a maioria do volume das Ondas. As idéias dominantes eram as da filosofia positiva de Augusto Comte, havendo alguns dissidentes, que liam Spencer, entre os quais se incluía Euclides.

\footnotetext{
${ }^{155}$ CARNEIRO, Paulo. Francisco Venâncio Filho: homem de ciência e educador. In: VENÂNCIO FILHO, Alberto. Francisco Venâncio Filho: Um Educador Brasileiro. Rio de Janeiro: Nova fronteira, 1995, p. 111-112. ${ }^{156}$ ABREU, Regina. O enigma de Os Sertões. Rio de Janeiro, Rocco, 1988.

${ }^{157}$ REALE, Miguel. Face Oculta de Euclides da Cunha. Rio de Janeiro: Topbooks, 1993.

${ }^{158}$ VENANCIO FILHO, Francisco. A Gloria de Euclydes da Cunha. Rio de Janeiro, Companhia Editora Nacional, 1940.
} 
Em trecho de outro texto de Venâncio Filho foi dado destaque ao período em que Euclides esteve ligado ao positivismo ${ }^{159}$ :

O Positivismo pode ser apreciado principalmente no seu aspecto científico, político e religioso. A sua influência no Brasil tem sido julgada mais de uma vez com flagrante injustiça por alguns escritores. Justa parece a admirável apreciação de Euclydes da Cunha, quando mostra o advento das correntes filosóficas do século XIX: "Apenas um exíguo grupo se afastou-se. Ninguém mais o viu - e mal se sabe que ele ainda existe, reduzido a dois homens admiráveis, que falam às vezes mas que se não ouvem, de tão longe lhes vêm a voz, tão longe eles ficaram no território ideal de uma utopia, no dualismo da positividade e do sonho.

No livro "História do positivismo no Brasil" ${ }^{160}$, de autoria do positivista Ivan Lins, que também estava ligado ao grupo dos euclidianos, por ser cunhado de Paulo Carneiro, há a seguinte afirmação:

Um quartel de século mais tarde desenvolveria as mesmas idéias de Martins Junior outro grande espírito, também altamente influenciado por Augusto Comte- Euclides da Cunha. Fê-lo ao prefaciar os Poemas e Canções de Vicente de Carvalho, seu correligionário filosófico, que chegou a filiar-se à Igreja Positivista do Brasil, como vimos em capítulo anterior.

Vicente de Carvalho, também caracterizado como positivista pelo autor, aparece entre os colaboradores do Grêmio Euclides da Cunha em seus anos iniciais ${ }^{161}$, demonstrando que a doutrina de Augusto Comte não era seguida apenas pelos principais euclidianos, mas também por outros colaboradores do Grêmio, como o citado poeta.

Com isso não se pretende dizer que todos os participantes do Grêmio fossem positivistas e que venerassem Euclides por sua postura científica e baseados em preceitos positivistas. Definitivamente, isso seria uma afirmação precipitada. Há, inclusive, nas revistas do Grêmio, vários artigos de euclidianos que exaltam inúmeras e diferentes qualidades de Euclides, que por vezes chegam até a ser contraditórias. Havia aqueles que louvavam o Euclides bandeirante; o Euclides nacionalista; o Euclides socialista, fundador do primeiro partido

\footnotetext{
${ }^{159}$ Discurso do Professor F. Venâncio Filho, lido pelo consócio Edgard Sussekind de Mendonça. In: Boletim da Associação Brasileira de Amigos de Augusto Comte. Mario Barboza Carneiro. In memorian. Rio de Janeiro: Jornal do Commercio, 1947, p. 67.

${ }^{160}$ LINS, Ivan Monteiro de Barros. História do Positivismo no Brasil. São Paulo: Ed Nacional, 1967, p. 327.

${ }^{161}$ Revista do Grêmio Euclydes da Cunha. Rio de Janeiro, 1919.
} 
socialista do país; e até o Euclides pai da sociologia criminal $^{162}$, ainda que possa parecer estranho que alguém possa ter sido socialista e pai da sociologia criminal ao mesmo tempo. Em texto intitulado "Euclides da Cunha e a sociologia criminal”, publicado na revista do Grêmio, Roberto Lyra afirmou ${ }^{163}$ :

N’Os Sertões não há uma só passagem estranha ao programa da Sociologia Criminal. Trata de criminosos e crimes. Em torno dos tipos e das organizações da chamada delinqüência sertaneja, examina as suas causas essenciais e profundas. Fatores psíquicos e antropológicos, agravados pelo medievalismo da constituição da sociedade, cultivam o gérmen do crime, produzindo uma psicologia mórbida no indivíduo e uma sugestão permanente no meio. Junta-se o estado perigoso individual ao estado perigoso social, num clima que bastaria para propiciar o delito.

A interpretação de Roberto Lyra sobre Euclides e seu livro não era semelhante à dos euclidianos que lideravam o Grêmio, que consideravam Euclides defensor dos sertanejos e da absorção do ‘Brasil atrasado’ pelo ‘Brasil civilizado'. No entanto, outra afirmação de Lyra, no mesmo texto citado, nos permite compreender o porquê da aceitação de seu texto pela revista do Grêmio 164: "Mais do que o maior e o melhor dos nossos escritores, Euclides é o único com cheiro de eternidade. O seu livro máximo constitui a história natural e social da nacionalidade."

Para os líderes euclidianos, qualquer manifestação de apoio ou de louvor à figura de Euclides da Cunha era bem recebida, independente dos motivos pelos quais cada afiliado havia se identificado com o escritor. O que parecia interessar era que o tom dos artigos fosse de uma veneração quase cega. Pouco importava o conteúdo, ou porque as pessoas se filiavam ao Grêmio e resolviam escrever para as suas revistas. Os textos publicados pelos euclidianos nas revistas do Grêmio Euclides da Cunha sugerem que o importante era que o Grêmio se tornasse conhecido nacionalmente e tivesse um número relevante de associados. Portanto, quanto mais associados, melhor ${ }^{165}$. No entanto, os dirigentes e principais colaboradores do Grêmio, que foram aqueles que estabeleceram as suas diretrizes, seus objetivos, seus rituais e celebrações, tinham uma formação ligada às ciências naturais e experimentais e ajudaram a

${ }^{162}$ Cfr. Revista do Grêmio Euclydes da Cunha. Rio de Janeiro: ago 1935. Revista do Grêmio Euclydes da Cunha. Rio de Janeiro: ago 1936. Revista no Grêmio Euclydes da Cunha. Rio de Janeiro: ago 1937. Revista no Grêmio Euclydes da Cunha. Rio de Janeiro: ago 1939.

${ }^{163}$ LYRA, Roberto. Euclides da Cunha e a sociologia criminal. In: Revista no Grêmio Euclydes da Cunha, São José do Rio Pardo: ago 1937.

164 Idem Ibidem.

${ }^{165}$ Revista do Grêmio Euclydes da Cunha. Rio de Janeiro, 1919-1939. 
fundar, na década de 40, a Associação Brasileira dos Amigos de Auguste Comte, institucionalizando a ligação, que já era perceptível mesmo antes dessa fundação, entre eles e o positivismo. Além disso, os três tiveram trajetórias ligadas à valorização da educação e do conhecimento científico nos mais variados campos, e não apenas na literatura.

\subsection{A valorização da literatura euclidiana como parte de um projeto de valorização da ciência}

Nesse processo de canonização do escritor, descrito acima, foi muito importante, além de Alberto Rangel, a atuação constante, dedicada e incansável de Edgard Sussekind de Mendonça, presidente do Grêmio Euclides da Cunha do Rio de Janeiro durante todo o período de sua existência, de Francisco Venâncio Filho, considerado o maior conhecedor da obra de Euclides da Cunha daquela época ${ }^{166}$ e também militante do Grêmio, e Roquette-Pinto, euclidiano, médico, professor e diretor do Museu Nacional. Se nos anos iniciais do grêmio foi Alberto Rangel o encarregado pela orientação dos então jovens admiradores de Euclides, nas décadas de 30 e 40 seriam os três euclidianos citados os mais atuantes na tarefa de levar adiante o Grêmio e seus principais objetivos. Os três possuíam, além da dedicação e da admiração por Euclides, outros pontos em comum, entre eles e com o próprio Euclides: a condição de homens comprometidos com a ciência e a educação. Todos os três integrantes do Grêmio Euclides da Cunha analisados com mais profundidade neste trabalho tinham, também, em comum, o compromisso com a melhoria da qualidade da educação em seu país. E para eles, melhorar a educação do país significava intensificar o ensino de ciência nas escolas, incluída aí a literatura científica representada por Euclides da Cunha. Apesar de graduados em Engenharia ou Medicina, todos optaram pela dedicação, integral ou parcial, ao magistério, assim como seu homenageado, Euclides da Cunha. Eles pareciam concordar com seu mestre em sua célebre afirmação ${ }^{167}$ :

Quando voltarem as forças vitoriosas que ora convergem aqui, completemos a vitória. Que pelas estradas, ora abertas à passagem dos

\footnotetext{
${ }^{166}$ Euclides da Cunha a seus amigos. In: Revista do Grêmio Euclides da Cunha. Rio de Janeiro, ago 1939.

${ }^{167}$ CUNHA, Euclides da. O Estado de São Paulo, 15 de Agosto de 1897. Disponível em:

http://pt.wikisource.org/wiki/Artigo de Euclides da Cunha de 15 de agosto de 1897. Acesso em Dezembro/2009.
} 
batalhões gloriosos, que por essas estradas amanhã silenciosas e desertas, siga depois da luta, modestamente, um herói anônimo, sem triunfos ruidosos, mas que será, no caso vertente, o verdadeiro vencedor: o mestreescola.

Edgard Sussekind de Mendonça, irmão do também euclidiano Carlos Sussekind de Mendonça e filho de Lucio de Mendonça, um dos fundadores da Academia Brasileira de Letras, foi aluno de Euclides da Cunha em seus últimos meses de vida, quando o escritor assumiu a cadeira de Lógica do Colégio Pedro II. No ano de 1911, em que o Grêmio foi fundado no interior da escola, eram os irmãos Sussekind as principais lideranças do movimento. Com o passar dos anos, Francisco Venâncio Filho assumiu, ao lado de Edgard, a condição de um dos principais líderes do movimento euclidiano, que antes pertencera a Carlos Sussekind de Mendonça.

Apesar disso, Carlos continuou a freqüentar a e a fazer parte do grupo dos euclidianos. Seu irmão, Edgard, substituiu Alberto Rangel na presidência da Instituição em homenagem a Euclides, e permaneceu neste posto até a sua morte, ocorrida na década de $50^{168}$. Mas, como já foi dito, além da dedicação à memória de Euclides da Cunha, que foi constante durante toda a sua vida, Edgard Sussekind de Mendonça também teve a vida marcada pela dedicação à educação. Apesar de não ter concluído o curso de Arquitetura na Escola Nacional de BelasArtes, Edgard Sussekind de Mendonça foi, por muitos anos, professor de desenho do Instituto de Educação.

Já na década de 20, quando seu irmão fundou a Livraria Científica, fica clara a ligação de ambos com o tema da educação. Segundo Diana Gonçalves Vidal ${ }^{169}$ :

Em 1922, ainda, Carlos S. de Mendonça, Francisco Venâncio Filho, Fernando Raja Gabaglia e Soter Célio de Araújo fundaram sob a razão social Süssekind de Mendonça \& Cia., a Livraria Científica Brasileira, liquidada dois anos mais tarde. Além de editar livros de diversos autores brasileiros, como Delgado de Carvalho, Afrânio Peixoto e Roquette-Pinto, a livraria oferecia suas instalações para aulas particulares ministradas por Pecegueiro do Amaral e Jaime Coelho, dentre outros. Uma das iniciativas da livraria foi a publicação da Revista Brasileira de Educação, segundo Carlos, germe da Associação Brasileira de Educação criada em 1924 e da qual Edgard foi um dos fundadores.

\footnotetext{
${ }^{168}$ Arquivo Euclides da Cunha. Série 7 Código de referência: BR ABL AA EC gec.In: Academia Brasileira de Letras.

${ }^{169}$ VIDAL, Diana Gomes. Edgard Sussekind de Mendonça. In: FÁVERO, Maria de Lourdes de Albuquerque; BRITTO, Jader de Medeiros. . Dicionário de educadores no Brasil: da colônia aos dias atuais. Rio de Janeiro: UFRJ/ MEC-Inep, 1999, p. 286.
} 
Boa parte dos nomes citados acima pela autora estará junta em diversas outras atividades, sempre ligadas ao mesmo tema: a educação popular, com ênfase na educação de cunho científico. O próprio nome dado pelo irmão de Edgard Sussekind de Mendonça a sua livraria já é uma demonstração da importância dada não só por eles, mas por boa parte do grupo de intelectuais que freqüentou a livraria e esteve presente em muitos outros empreendimentos, ao conhecimento científico.

Paulo Carneiro, em depoimento póstumo sobre Francisco Venâncio Filho intitulado "Francisco Venâncio Filho: homem de ciência e educador”, e com epígrafe dedicada à memória de Edgard Sussekind de Mendonça, também mencionou os tempos da Livraria Científica ${ }^{170}$ :

Quando ainda havia em nossa cidade, nos cantos de certas ruas, livrarias que se constituíam em salões literários, lugares de encontro marcados pela presença de prestigiosas figuras que em torno delas congregavam admiradores e amigos, uns na casa Garnier, outros à porta da Francisco Alves, tinha Venâncio Filho o seu próprio ponto de reunião, na Livraria Científica, criada e dirigida por Carlos Sussekind de Mendonça, seu fraternal amigo, à rua São José. À tarde, ali se juntavam homens de ciência $e$ homens de letras, professores e estudantes, personalidades ilustres do jornalismo e do teatro, ao lado de obscuros boêmios atraídos pelas celebridades. Lá apareciam com freqüência, Heitor Lira e Afrânio Peixoto, Roquette-Pinto e Edgard de Mendonça, João Carlos Vital, Celso Kelly, Raja Gabaglia, Jonatas Serrano, Raul Bittencourt, Delgado de Carvalho, Faria Góes, Gustavo Lessa, Alair Antunes, Tude de Souza... De quando em vez, vinha-lhes ao encontro Capistrano de Abreu, à busca de livros. Frequentei, por algum tempo, esse cenáculo de beira de calçada, em que se discutiam apaixonadamente os problemas cruciais da educação no Brasil, à luz das mais diversas correntes de pensamento, num clima de liberdade e tolerância que não tardaria a desaparecer".

Nas décadas de 20 e 30, Edgard Sussekind de Mendonça participou da criação da Associação Brasileira de Educação e foi um dos signatários do Manifesto dos Pioneiros da Escola Nova, assim como Roquette-Pinto, Venâncio Filho, Afrânio Peixoto, e outros euclidianos. De acordo com Vanessa Carvalho Nofuentes ${ }^{171}$ :

\footnotetext{
170 CARNEIRO, Paulo. Francisco Venâncio Filho: homem de ciência e educador. In: VENÂNCIO FILHO, Alberto. Francisco Venâncio Filho: um educador brasileiro. Rio de Janeiro: Nova Fronteira, 1996, p. 101. ${ }^{171}$ NOFUENTES, Vanessa Carvalho. PONTIFÍCIA UNIVERSIDADE CATÓLICA DO RIO DE JANEIRO Departamento de História. . Um desafio do tamanho da nação: a campanha da Liga Brasileira Contra o Analfabetismo (1915-1922). 2008. 163 f. Dissertação (Mestrado em História)-Pontifícia Universidade Católica do Rio de Janeiro, Rio de Janeiro, 2008, p. 134.
} 
Fundada em 15 de outubro de 1924, no anfiteatro da antiga Escola Politécnica, a ABE não se definia como um órgão de classe, contando com a participação de engenheiros, médicos, advogados e educadores. A associação teve como fundadores Heitor Lyra da Silva (líder do grupo formado por expressiva maioria de engenheiros), Fernando Laboriau, Dulcídio Pereira, Amoroso Costa, Isabel Lacombe, Alice Carvalho de Mendonça, Amaury de Medeiros (médico) e José Augusto (advogado). Contou ainda com a participação de Paulo Carneiro, Venâncio Filho, Edgar Sussekind de Mendonça, Everardo Backeuser, Álvaro Alberto, Menezes de Oliveira e muitos outros engenheiros. A corrente médica faziase representar por nomes como Fernando de Magalhães, Roquette Pinto, Artur Moses, Gustavo Lessa, Carlos Sá e Miguel Couto. Este último pronunciaria na $A B E$ uma célebre conferência ressaltando que "no Brasil só existe um problema: o da educação de seu povo". Professores de todos os graus e níveis não poderiam deixar de aderir à instituição e entre estes destacamos os nomes de Anísio Teixeira, Lourenço Filho, Fernando de Azevedo, Consuelo Pinheiro, Paschoal Lemme, Juracy Silveira, Franklin Botelho de Magalhães e Basílio de Magalhães.

Alguns dos nomes que aparecem nos trechos destacados, como Raja Gabaglia, que foi diretor do Colégio Pedro II, Lourenço Filho, diretor geral do Departamento Nacional de Educação (1937) e do Instituto Nacional de Estudos Pedagógicos (1938-1946) e Anísio Teixeira, diretor da Instrução Pública do Distrito Federal (1931) e fundador da Universidade do Distrito Federal (1935), estiveram ligados aos três euclidianos em várias atividades, e foram fundamentais para que eles conseguissem, anos mais tarde, incluir Euclides da Cunha como literatura obrigatória nas escolas. Como veremos, essa rede de relações construída pelos euclidianos, que envolvia não apenas admiradores de Euclides, mas também autoridades de outras áreas, foi fundamental para consolidar Euclides na posição de grande escritor nacional ${ }^{172}$.

Ainda na década de 20, Edgard Sussekind de Mendonça participou da fundação, juntamente com sua esposa, Armanda Álvaro Alberto, e com seu amigo Francisco Venâncio Filho, da Escola Regional de Meriti e foi o primeiro locutor da Rádio Sociedade do Rio de Janeiro, em empreendimento conjunto com Roquette-Pinto.

Essa mesma militância de Edgard pelos temas da educação acabou levando-o à prisão, no ano de 1935, no governo de Vargas. O professor, que deixou claro em diversos escritos a sua oposição ao ensino religioso nas escolas, foi acusado de comunismo, e mais tarde absolvido,

\footnotetext{
${ }^{172}$ ABREU, Regina. O Enigma de Os Sertões. Rio de Janeiro, Funarte; 1988 p. 308.
} 
já que a acusação nunca foi provada ${ }^{173}$. O conhecimento da militância de Sussekind de Mendonça em inúmeras outras causas nos permite levantar a suspeita de que teriam sido as suas firmes convicções científicas ou até mesmo positivistas, e não o comunismo, que o levaram a se opor ao ensino religioso e a defender a laicização das escolas. Assim como ele, Edgard Roquette-Pinto também teve sua biografia marcada pela dedicação à ciência, a Euclides da Cunha e à educação.

Roquette-Pinto, professor do Externato Aquino, do Colégio Pedro II e diretor do Museu Nacional por muitos anos, foi um cientista, educador, euclidiano e de formação positivista, que contou com a parceria de Edgard Sussekind de Mendonça e de Francisco Venâncio filho em muitos de seus projetos ${ }^{174}$. Nos anos iniciais da agremiação, Roquette-Pinto foi um aliado fundamental dos estudantes fundadores do Grêmio Euclides da Cunha do Rio de Janeiro. Foi graças à doação dos direitos de livros e palestras proferidas por ele que o Grêmio obteve os seus primeiros rendimentos. Médico de formação, o professor não chegou a exercer a medicina, e preferiu seguir a profissão de naturalista e educador, tendo sido também um dos pioneiros das transmissões radiofônicas no país. Além disso, Roquette-Pinto foi um dos idealizadores do Instituto Nacional do Cinema Educativo que, como será explicado adiante, foi um dos importantes instrumentos utilizados pelos euclidianos para a divulgação da obra de Euclides da Cunha a um público mais amplo que o de seus leitores. A sua condição de positivista é confirmada no discurso de recepção de Ivan Lins a Paulo Carneiro, também positivista, na Academia Brasileira de Letras. Na ocasião, disse Ivan Lins ${ }^{175}$ :

Mas, tal qual como aconteceu com Martins Júnior, Vicente de Carvalho e Roquette Pinto, não é pelas vossas conviç̧ões positivistas que aqui ingressais, porque a nossa Academia, assim como a Francesa, conforme advertia Renan a Pasteur, não patrocina doutrinas: apenas discerne talentos. Salientava com razão Aloísio de Castro: "Jamais houve aqui dogmatismos de qualquer natureza; aqui não se denunciam excomunhões $e$ não é da Academia que vem o grito: nós é que somos a verdade!

\footnotetext{
${ }^{173}$ VIDAL, Diana Gomes. Edgard Sussekind de Mendonça. In: FÁVERO, Maria de Lourdes de Albuquerque; BRITTO, Jader de Medeiros. . Dicionário de educadores no Brasil: da colônia aos dias atuais. Rio de Janeiro: UFRJ/ MEC-Inep, 1999.

${ }^{174}$ VENANCIO FILHO, Alberto. Edgar Roquette-Pinto. In: FÁVERO, Maria de Lourdes de Albuquerque; BRITTO, Jader de Medeiros. . Dicionário de educadores no Brasil: da colônia aos dias atuais. Rio de Janeiro: UFRJ/ MEC-Inep, 1999.

${ }^{175}$ LINS, Ivan. Conferências na Academia Brasileira de Letras. Rio de Janeiro: Academia Brasileira de Letras; 1973 p. 87.
} 
Em 1906, um ano após ter concluído o curso de Medicina pela faculdade de Medicina do Rio de Janeiro, Roquette-Pinto foi nomeado professor assistente de Antropologia do Museu Nacional. Em 1912, participou da chamada Comissão Rondon, na qual o professor colheu material para escrever seu livro de maior expressão, intitulado “Rondônia”. Segundo Alberto Venâncio Filho ${ }^{176}$ :

Participou, em 1912, da comissão dirigida pelo Marechal Candido Rondon para a construção das linhas telegráficas e, como resultado dessa viagem, publicou o notável estudo Rondônia, expressão dada à região em homenagem ao Marechal Rondon.

Alguns anos depois de participar da Comissão Rondon, Roquette-Pinto retornou à Capital Federal, onde deu continuidade às suas atividades no magistério e no Museu Nacional. Como diretor do Museu Nacional, Roquette-Pinto contribuiu para a glorificação científica de Euclides da Cunha, através da criação, por ele, da Sala Euclides da Cunha dentro do museu. Além disso, ele escreveu uma série de artigos ressaltando a identidade do escritor com a ciência ${ }^{177}$. Todas as atividades desenvolvidas por Roquette-Pinto com o objetivo de divulgar e popularizar a obra de Euclides da Cunha serão analisadas com mais profundidade no capítulo seguinte.

Francisco Venâncio Filho entrou em contato com Roquette ainda antes de sua participação na citada comissão, no Externato Aquino, o mesmo em que havia estudado Euclides. Segundo depoimento do próprio Roquette-Pinto ${ }^{178}$ :

Durante 37 anos, de 1909 a 1946, acompanhei dia a dia a grande vida luminosa e justa de Francisco Venâncio. Naquele ano de 1909 tive honra de ser escolhido para substituir, na cátedra de História Natural do Externato Aquino, o meu antigo professor A. Pacheco Leão. Voltei àquela casa acolhedora e digna, de onde, em 1900, saíra para a Faculdade de Medicina... Na turma confiada ao meu ensino tive a fortuna de encontrar moços inteligentes, dedicados e honestos. Entre eles, estavam lá Pitanga de Almeida, Fernando Raja Gabaglia e Francisco Venâncio Filho.

\footnotetext{
${ }^{176}$ VENANCIO FILHO, Alberto. Edgar Roquette-Pinto. In: FÁVERO, Maria de Lourdes de Albuquerque; BRITTO, Jader de Medeiros. . Dicionário de educadores no Brasil: da colônia aos dias atuais. Rio de Janeiro: UFRJ/ MEC-Inep, 1999, p. 282.

${ }_{177}$ ABREU, Regina. O Enigma de Os Sertões. Rio de Janeiro, Funarte; 1988.

178 APUD CARNEIRO, Paulo. Francisco Venâncio Filho: homem de ciência e educador. In: VENÂNCIO FILHO, Alberto. Francisco Venâncio Filho: um educador brasileiro. Rio de Janeiro: Nova Fronteira, 1996, p. 97.
} 
O colégio, famoso pela ênfase que dava às chamadas ciências naturais, ainda era, na época de Venâncio, uma das instituições mais indicadas para preparar os alunos para o curso de Engenharia. Decidido a entrar para esse curso, Venâncio Filho foi matriculado nessa escola e, a partir daí, graças à sugestão de Roquette Pinto, entrou em contato com a obra Euclidiana. Não demoraria para que ele aderisse ao grêmio. Isso ocorreu no ano de $1913^{179}$. Nos anos subseqüentes, Venâncio Filho foi ganhando cada vez mais espaço dentro do Grêmio. Escrevia artigos para o Jornal do Commercio a respeito do escritor, organizava as homenagens, trazia novos adeptos. Nas palavras de seu filho ${ }^{180}$ :

Ora, desde que, em 1913, o Grêmio Euclides da Cunha saiu do Pedro II e veio para cá fora não teve mais exato, mais pontual, mais piedoso do que Francisco Venâncio Filho. Ele vivia buscando, pedindo, recolhendo, catando qualquer dado novo sobre seu patrono. A mínima informação inédita sobre Euclides, ele a recebia como uma dádiva real. Qualquer artigo perdido, que de longe interessasse à obra ou à glória do mestre ele o recopiava com amor.

Em pouco tempo, o engenheiro-escritor-professor passou a ser citado como um dos maiores especialistas, senão o maior, em Euclides da Cunha pelos próprios companheiros do Grêmio ${ }^{181}$. Em texto da Revista do Grêmio Euclides da Cunha intitulado "Euclides da Cunha a seus amigos”, aparece a seguinte afirmação:

Da notícia sobre a sessão da Academia Brasileira realizada no dia 22 de Dezembro de 1938 consta o seguinte:

--- O Sr. Roquette-Pinto ofereceu, em nome do autor, à biblioteca da Academia, o volume 'Euclides da Cunha a seus amigos', do S. Francisco Venâncio Filho. As cartas de Euclides da Cunha foram reunidas $e$ comentadas superiormente pelo ilustre escritor, que é a nossa maior autoridade em tudo quanto diz respeito ao mestre de Os Sertões. A carinhosa e inteligente dedicação de Venâncio Filho, exemplo de civismo, mais uma vez, presta a Euclides da Cunha o culto que tem sido edificante prova de singular elevação moral. Pelos comentários sempre interessantes e pelo estilo simples, conceituoso e claro, o livro de Venâncio Filho é contribuição singular e útil à história do pensamento brasiliano. ${ }^{182}$

\footnotetext{
${ }^{179}$ Idem Ibidem.

${ }^{180}$ VENÂNCIO FILHO, Alberto. O Movimento Euclidianista, IN: Ciclo Comemorativo da Publicação de Os Sertões, 2002, Rio de Janeiro. Disponível em: www.abl.org.br. Acesso em outubro de 2004, p. 2.

${ }^{181}$ FILHO, Alberto. Francisco Venâncio Filho: um educador brasileiro. Rio de Janeiro: Nova Fronteira, 1996.

${ }^{182}$ Euclides da Cunha a seus amigos. In: Revista do Grêmio Euclides da Cunha. Rio de Janeiro, ago 1939.
} 
A militância euclidiana passou a ser quase uma obsessão para ele. Nas palavras de seu companheiro e professor, Roquette- Pinto:

Do próprio culto à memória de Euclides da Cunha, grande traço de sua existência, Venâncio fez surgir um momento de educação cívica sem paralelo no Brasil, tornando a cidade de São José do Rio Pardo um lugar de solenidades anuais do maior alcance social ${ }^{183}$.

Múcio Leão, outro euclidiano, escreveu coisas parecidas sobre Venâncio Filho: "Seu culto por Euclides da Cunha foi obsessivo, e acabou sendo a única verdadeira expressão de sua existência” ${ }^{184}$.

No entanto, e assim como seus dois companheiros de militância euclidiana, Venâncio Filho também dedicou boa parte de sua energia para lutar pelas causas da educação de cunho científico. Ainda de acordo com Roquette-Pinto ${ }^{185}$ : "O problema essencial que a sua mocidade encontrou, foi a educação popular. O engenheiro civil trocou a carreira do construtor pela do apostolado da cultura do povo".

Venâncio Filho colaborou ativamente na maioria dos movimentos educacionais emergidos entre as décadas de 20 e 30. Foi fundador da ABE, signatário do Manifesto dos Pioneiros da Escola Nova e colaborador de autoridades da educação da época, como Fernando de Azevedo e Anísio Teixeira, ambos ex-diretores da Instrução Pública do Distrito Federal ${ }^{186}$ : “Foi um colaborador eficiente da reforma de Fernando de Azevedo no antigo Distrito Federal e da sua continuação nas reformas de Anísio Teixeira."

De acordo com Paulo Carneiro, em texto já citado anteriormente, foi o também euclidiano Afrânio Peixoto que apresentou Venâncio Filho ao educador Anísio Teixeira. Alguns

\footnotetext{
183 APUD VENÂNCIO FILHO, Alberto. O Movimento Euclidianista, IN: Ciclo Comemorativo da Publicação de Os Sertões, 2002, Rio de Janeiro. Disponível em: www.abl.org.br. Acesso em outubro de 2004, p. 1.

${ }^{184}$ Idem. Ibidem, p.1.

${ }^{185}$ CARNEIRO, Paulo. Francisco Venâncio Filho: homem de ciência e educador. In: VENÂNCIO FILHO, Alberto. Francisco Venâncio Filho: um educador brasileiro. Rio de Janeiro: Nova Fronteira, 1996, p. 98. ${ }^{186}$ SUCUPIRA, Newton Lins Buarque. Francisco Venâncio Filho. In: FÁVERO, Maria de Lourdes de Albuquerque; BRITTO, Jader de Medeiros. . Dicionário de educadores no Brasil: da colônia aos dias atuais. Rio de Janeiro: UFRJ/ MEC-Inep, 1999, p. 402.
} 
depoimentos de Paulo Carneiro sobre Venâncio Filho demonstram com clareza a importância que o autor dava à educação e à ciência ${ }^{187}$ :

Professor de Física, tinha Francisco Venâncio constantemente em vista as invenções e descobertas que pudessem melhorar a difusão dos conhecimentos, em escala mundial. Quando, a 7 de Setembro de 1922, ouviu as primeiras emissões de rádio no Brasil, teve imediata percepção do campo maravilhoso que se abria à educação das massas num país da extensão do nosso, em grande parte habitado por populações rurais dispersas, sem contato direto com a civilização. Associou-se imediatamente à iniciativa tomada por Roquette-Pinto de fundar a Rádio Sociedade do Rio de Janeiro. A 20 de Abril de 1923, estava ela constituída. Com a fidelidade que era traço dominante do seu caráter, tornou-se Venâncio, desde então, um dos esteios da campanha dirigida por Roquette-Pinto para implantar no Brasil esse novo instrumento de educação e cultura. Dela participaram, desde o primeiro momento, Henrique Morize, Francisco Lafayette, Dulcídio Ferreira, Álvaro e Miguel Osório de Almeida, Costa Lima, Betim Paes Leme, Everardo Beckheuser, Edgard e Carlos Sussekind de Mendonça. Em 1936, ofereceu Roquette-Pinto as instalações da Rádio Sociedade ao Ministério da Educação, onde até agora se acha abrindo ao povo o acesso a todas as formas de saber.

Dentro do mesmo espírito, e com o mesmo objetivo, promoveu Roquette, em 1934, a criação do Instituto Nacional do Cinema Educativo. Foi uma das iniciativas mais fecundas por ele tomadas. Vinha ela ao encontro das aspirações de numerosos educadores do país. Desde 1931, clamava Venâncio Filho por tal instituição. Um dos seus livros, publicado naquele ano, atesta o seu clarividente propósito. Era o cinema, então, o tema de eleição de numerosos intelectuais brasileiros. Na revista Fan, Octavio de Faria e seus amigos pregavam o credo do cinema puro, pondo em confronto a imagem e a palavra. A Venâncio, interessava mais o papel do cinema como fator de civilização.

No mesmo texto citado acima, Paulo Carneiro também mencionou a dedicação de Venâncio Filho por Euclides da Cunha. Segundo o autor ${ }^{188}$ :

Fiel à sua missão de professor, escreveu, sem cessar, Venâncio Filho sobre as matérias que ensinava. A bibliografia dos seus trabalhos de caráter científico e educacional estende-se de 1924 a 1946. Desde 1914, consagrava, porém, artigos e ensaios à vida e à obra de Euclides da Cunha, num preito de admiração que exaltou e engrandeceu toda a sua existência.

Os trechos destacados acima evidenciam que, nas inúmeras iniciativas em que os três euclidianos estiveram envolvidos, a questão da educação como instrumento de civilização dos

\footnotetext{
${ }^{187}$ CARNEIRO, Paulo. Francisco Venâncio Filho: homem de ciência e educador. In: VENÂNCIO FILHO, Alberto. Francisco Venâncio Filho: um educador brasileiro. Rio de Janeiro: Nova Fronteira, 1996, p. 107-108. ${ }^{188}$ Idem Ibidem, p. 105.
} 
povos esteve sempre presente. Havia, da parte dos intelectuais estudados, um compromisso não apenas com a divulgação da obra de Euclides, mas também com ações voltadas a educar, civilizar e diminuir o fosso entre os dois Brasis, que tanto preocupou Euclides e que preocupava igualmente a esses homens ${ }^{189}$. Para eles, a criação da rádio, do Instituto de Cinema Educativo e de revistas voltadas para o público escolar eram fundamentais no processo de modernização e de democratização da educação. De acordo com correspondências e documentos do Arquivo Euclides da Cunha analisados, o cinema e o rádio eram vistos por eles como instrumentos educacionais mais democráticos, pois não exigiam a alfabetização de seus ouvintes e espectadores ${ }^{190}$.

Desse modo, e como já foi apontado, ao mesmo tempo em que militavam pela imortalidade de Euclides da Cunha através da divulgação de sua obra, os euclidianos também militavam em movimentos a favor da modernização, da laicização e da valorização da educação, com ênfase no conhecimento científico. O trecho sobre a fundação da $\mathrm{ABE}$, da qual todos os intelectuais citados foram integrantes, e sobre a participação dos euclidianos em movimentos como o Escola Nova reiteram a ligação dos euclidianos nas questões educacionais de seu tempo.

Essa preocupação com a valorização do conhecimento científico também é uma das características dos intelectuais positivistas. Ângela Alonso, em texto denominado "Raízes positivistas do reformismo nos anos 1930”, aponta a existência das mesmas preocupações em Paulo Carneiro que, como mencionado, fez parte do círculo de amizades dos euclidianos estudados $^{191}$ :

O positivismo se manifestou na eleição por Paris- capital do Ocidente, segundo a doutrina-, na opção pela carreira científica e por um trabalho que tratasse de problemas locais e pudesse ter impactos práticos: Paulo Carneiro fez tese sobre o guaraná. Em Paris, prestou homenagem a Comte, indo visitar-lhe a casa. Acabou tornando-se responsável e financiador dos manuscritos do mestre.

Mais adiante, completa a autora ${ }^{192}$ :

\footnotetext{
${ }^{189}$ ABREU, Regina. O Enigma de Os Sertões. Rio de Janeiro, Funarte; 1988.

${ }^{190}$ Arquivo Euclides da Cunha. Série 7 Código de referência: BR ABL AA EC gec. In: Academia Brasileira de Letras.

${ }^{191}$ ALONSO, Ângela. Raízes positivistas do reformismo nos anos 1930. In: MAIO, Marcos Chor. Ciência, Política e Relações Internacionais. Ensaios sobre Paulo Carneiro. Rio de Janeiro, editora Fiocruz, 2004, p. 32.
} 
Do ângulo científico, o Paulo Carneiro da década de 1930, com trinta anos ele também, trazia uma crença inabalável nas capacidades civilizatórias da ciência. (...) O positivismo estrutura, sobretudo a visão de Paulo Carneiro no que diz respeito à relação entre ciência e política. Via a ciência como o caminho e as instituições científicas como instrumento indispensável do progresso.

Sabendo da relação dos três com o positivismo, é possível fazer uma relação entre essa dedicação ao campo educacional e com a valorização do conhecimento científico e o ideal positivista de progresso e de civilização, que seria alcançado por meio da educação dos povos. A concepção de educação defendida pelos euclidianos e destacada nos trechos acima é, também, bastante semelhante à proposta teórica educacional dos positivistas. A própria formação dos três, em cursos de ciências exatas e naturais, pode ter contribuído para criar essa semelhança. Sobre a educação na perspectiva do positivismo, afirmam Jamil Ibrahim Iskandar e Maria Rute Leal ${ }^{193}$ :

Os positivistas se empenharam em combater a escola humanista, religiosa, para favorecer a ascensão das ciências exatas. As idéias positivistas influenciaram a prática pedagógica na área das ciências exatas, influenciaram a prática pedagógica na área de ensino de ciências sustentadas pela aplicação do método científico: seleção, hierarquização, observação, controle, eficácia e previsão.

Ainda sobre a educação do ponto de vista do positivismo:

Os ideais de ordem e progresso na educação aparecem sob forma de disciplina e educação, respectivamente, como processo evolutivo.

Por progresso entende-se que o aluno, como membro da sociedade, deve passar por fases evolutivas: o pensamento teológico, o metafísico e, por fim, o positivo. A superação da metafísica levaria o homem a fugir de especulações. A presença de planejamento visando ao alcance de objetivos também ilustra os ideais de ordem e progresso.

Uma das falas de Roquette-Pinto citadas por Paulo Carneiro em seu discurso demonstram como ele utilizava a idéia positivista de etapas de desenvolvimento e progresso histórico das nações e dos povos para diagnosticar o problema da educação no Brasil. Além disso, segundo nos informa Paulo Carneiro, Venâncio Filho planejava a criação de um Museu de Ciência, em que os grandes gênios da humanidade estariam representados. Na Igreja Positivista, esses

\footnotetext{
192 Idem Ibidem, p.33-34.

${ }^{193}$ ISKANDAR, Jamil Ibrahim e LEAL, Maria Rute. Sobre positivismo e educação. In: Revista Diálogo Educacional, Curitiba, v. 3, n.7, p. 89-94, set./dez. 2002.
} 
mesmos gênios, ou seja, pessoas que tenham se destacado na produção de conhecimento científico, denominados de 'Vultos da Humanidade', recebem homenagens parecidas, como estátuas, dias santos e meses dedicados ao estudo de sua vida e obra. Segundo Carneiro: À educação pelos meios tradicionais, a palavra, o livro, a revista, juntavam-
se, agora, com o rádio e o cinema, dois instrumentos de alcance ilimitado. À
frente dos que se bateram pela sua imediata utilização no ensino público
encontravam-se Francisco Venâncio e seus amigos Edgard de Mendonça e
Jonatas Serrano. Tinham todos em mente a advertência de Roquette-Pinto:
"O Brasil atingiu o máximo de progresso compatível com a situação de
atraso intelectual da maioria de seus filhos".

A importância dos museus na instrução popular foi constantemente evocada por Francisco Venâncio, à luz do que viu em numerosas cidades da Alemanha, da França, da Inglaterra.

(...) Planejou mesmo um Museu de Ciência, em que a juventude brasileira pudesse aprender, ao percorrê-lo, tudo o que conceberam e descobriram, no curso dos séculos, os grandes gênios da humanidade.

De caráter mais acessível, e destinados ao grande público, são os seus inúmeros ensaios de vulgarização científica. Muitos deles se referem às obras e aos homens de ciência do Brasil, desde o período colonial até o primeiro quarto deste século. ${ }^{194}$

Portanto, seja em atividades internas do Grêmio Euclides da Cunha, seja em atividades ligadas à educação, os euclidianos estudados neste trabalho estiveram fortemente envolvidos em iniciativas de valorização do conhecimento e da literatura científica. Euclides da Cunha, por ter unido “ciência e arte em uma só peça” ${ }^{195}$, nas palavras de Venâncio Filho, era merecedor, sob o ponto de vista dos três maiores colaboradores do Grêmio, de ocupar o posto de maior escritor nacional e de receber todas as honrarias dedicadas a ele pelo Grêmio ${ }^{196}$.

Essa postura, de realce dos aspectos científicos na obra de Euclides, aliada a uma série de outros projetos nos quais os euclidianos estiveram envolvidos, também ligados à proposta de uma educação de cunho científico, nos leva a crer que estes intelectuais e militantes estavam engajados na construção de um projeto de sociedade e literatura, no sentido empregado por

${ }^{194}$ CARNEIRO, Paulo. Francisco Venâncio Filho: homem de ciência e educador. In: VENÂNCIO FILHO, Alberto. Francisco Venâncio Filho: um educador brasileiro. Rio de Janeiro: Nova Fronteira, 1996, p. 107-108. ${ }^{195}$ VENÂNCIO FILHO, Francisco. Fundamentos Científicos de Os Sertões. IN Revista Brasileira. Rio de Janeiro: ano 5, n.9, dez. 1945 p.70.

${ }^{196}$ VENANCIO FILHO, Alberto. Francisco Venâncio Filho: um educador brasileiro. Rio de Janeiro: Nova Fronteira, 1996. 
Gilberto Velho no artigo “Memória, Identidade e Projeto” ${ }^{197}$, que passava pela fabricação de um herói que se aproximasse do modelo por eles imaginado. Nas palavras do próprio autor:

Alfred Schutz desenvolveu a noção de projeto como 'conduta organizada para atingir finalidades específicas. Embora o ator não seja necessariamente um indivíduo, podendo ser um grupo social, um partido, ou outra categoria, creio que toda a noção de projeto está indissoluvelmente imbricada à idéia de indivíduo-sujeito. Ou invertendo a colocação- é indivíduo-sujeito aquele que faz projetos. A consciência e valorização de uma individualidade singular, baseada em uma memória que dá consistência à biografia, é o que possibilita a formulação e condução de projetos. Portanto, se a memória permite uma visão retrospectiva mais ou menos organizada de uma trajetória e biografia, o projeto é a antecipação no futuro dessas trajetória e biografia, na medida em que busca, através do estabelecimento de objetivos e fins, a organização dos meios através dos quais esses poderão ser atingidos. A consistência do projeto depende, fundamentalmente, da memória que fornece os indicadores básicos de um passado que produziu as circunstâncias do presente, sem a consciência das quais seria impossível ter ou elaborar projetos. Não pretendo, nem Schutz pretendia, trabalhar com a idéia de indivíduosujeito cognitivo racional, capaz de armar estratégias e fazer cálculos, organizando seus dados e atuando cerebralmente. As circunstâncias de um presente do indivíduo envolvem, necessariamente, valores, preconceitos, emoções. O projeto e a memória associam-se e articulam-se ao dar significado à vida e às ações dos indivíduos, em outros termos, à própria identidade. $\mathrm{Ou}$ seja, na constituição da identidade social dos indivíduos, com particular ênfase nas sociedades e segmentos individualistas, a memória e o projeto individuais são amarras fundamentais. São visões retrospectivas e perspectivas que situam o indivíduo, suas motivações e o significado de suas ações, dentro de uma conjuntura de vida, na sucessão das etapas de sua trajetória.

\section{Gilberto Velho)}

Gagnebin, em livro intitulado “Lembrar, escrever, esquecer”, também relaciona memória a projeto e identidade ${ }^{198}$ :

A memória é fragmentada. O sentido de identidade depende em grande parte da organização desses pedaços, fragmentos de fatos $e$ episódios separados. O passado, assim, é descontínuo. A consistência $e$ o significado desse passado e da memória articulam-se à elaboração de projetos que dão sentido e estabelecem continuidade entre esses diferentes momentos e situações.

\footnotetext{
${ }^{197}$ VELHO, Gilberto. "Memória, Identidade e Projeto”. In: Projeto e metamorfose: antropologia das sociedades complexas. 2. ed. Rio de Janeiro: J. Zahar, 1999, p. 101.

${ }^{198}$ GAGNEBIN, Jeanne Marie. Lembrar escrever esquecer. São Paulo: Editora 34, 2006, p. 55.
} 
Nesse sentido, a idéia de construção de um mito e de uma memória que, além de associar Euclides ao positivismo, o coloca entre os principais escritores nacionais, pode estar ligada a um projeto, levado a cabo por estes intelectuais, de valorização da literatura científica, justamente no momento em que, de acordo com Ivan Lins ${ }^{199}$, o positivismo começa a entrar em descrédito no Brasil. Venâncio Filho e Roquette-Pinto, que, juntamente com Rondon, ele também positivista e euclidiano, e outros naturalistas do Museu Nacional, representavam apenas os resquícios do que havia sido o positivismo no Brasil, pareciam pretender, mais do que exaltar a figura de Euclides apenas por paixão pelo escritor, valorizar um tipo específico de literatura, que talvez fosse, na época, menos valorizada que a literatura ficcional produzida por Machado de Assis e que tinha em Euclides da Cunha um dos maiores, senão o maior representante. Dessa maneira, acredito que a valorização de Euclides da Cunha e da literatura de cunho científico representada por ele estava integrada aos vários outros movimentos de valorização do conhecimento científico dos quais os euclidianos fizeram parte. Seja nas manifestações em defesa da Escola Nova, seja na fundação da ABE, seja na defesa apaixonada da literatura de Euclides da Cunha, os euclidianos tinham compromisso com a defesa do conhecimento científico, e manifestaram esse compromisso em várias ocasiões de suas vidas.

Não se pretende, com isso, afirmar que toda a militância dos euclidianos positivistas fora apenas pragmática, relacionada a um projeto maior de valorização de um tipo de literatura. A admiração, que beirava a adoração desses intelectuais por Euclides da Cunha é mais do que clara, e não é intenção deste trabalho questioná-la. Pretende-se apenas lançar a hipótese de que, mais do que uma adoração descompromissada, esse movimento podia estar ligado a um projeto mais amplo, ainda que não tenha sido conscientemente arquitetado, de valorização de um modelo de literatura associado a uma postura científica, vista por esses intelectuais como o modelo literário ideal ${ }^{200}$. Essa mesma valorização do conhecimento científico pelos euclidianos também ocorreu em outra instituição: a Associação Brasileira dos Amigos de Augusto Comte.

\footnotetext{
${ }^{199}$ Cfr. LINS, Ivan Monteiro de Barros. História do Positivismo no Brasil. São Paulo: Ed Nacional, 1967. ${ }^{200}$ VENANCIO FILHO, Francisco. A Gloria de Euclydes da Cunha. Rio de Janeiro, Companhia Editora Nacional, 1940.
} 


\subsection{A outra face do engajamento: a Associação Brasileira dos Amigos de Auguste} Comte

A Associação Brasileira dos Amigos de Augusto Comte, fundada no ano de 1945 por Mario Carneiro definia-se como “conciliante de fato, infalível em princípio” ${ }^{201}$. Dizia, em seu estatuto, datado de cinco de julho de mil novecentos e quarenta e cinco, que não se empenharia em nenhuma atividade de ordem espiritual e que era reconhecida pelo governo francês. Contava com 136 associados, entre eles Francisco Venâncio Filho, tesoureiro da instituição, Roquette-Pinto, os irmãos Sussekind de Mendonça, Elói Pontes, Ivan Lins e vários membros da família Carneiro, entre eles Paulo Carneiro, filho de Mario e responsável, desde a década de 20, pela organização e conservação da Casa de Augusto Comte, em Paris $^{202}$. A instituição definia-se, portanto, como um local de admiração e cultivo da memória do filósofo francês que, no entanto, não enveredaria por um caminho de veneração de viés religioso, como fazia a Igreja Positivista do Brasil. A criação dessa instituição representou a confirmação da dissidência que havia entre a família Carneiro e os membros da Igreja Positivista do Brasil, desde que uma descoberta de Carneiro, em Paris, desagradou aos líderes da igreja brasileira.

De acordo com Priscila Fraiz e Eduardo Queiroz Reis, após a morte de Comte, dois franceses foram considerados os legítimos sucessores do filósofo: Pierre Laffitte e Émile Littré. Se o segundo preferiu seguir apenas as diretrizes filosóficas do escritor, recusando os pressupostos da religião da humanidade, o primeiro aceitou sem crítica toda a obra do escritor, tendo por isso sido encarregado de executar o testamento de Comte após a sua morte. Nas palavras dos autores $^{203}$ :

Para Laffitte e os partidários da religião, Comte tinha uma áurea quase mítica, sendo sempre tratado como o mestre, e tudo o que lhe pertenceu tornou-se relíquia sagrada. No contexto dessa vertente de sacralização, Comte deixaria ordens a serem cumpridas por seus discípulos após sua morte, visando à conservação de seu apartamento e tudo que havia nele, incluindo mobiliário e arquivos. Para isso, nomeou Laffitte como presidente e organizador da execução testamentária.

\footnotetext{
${ }^{201}$ Ata de fundação da Associação Brasileira de Amigos de Auguste Comte. 05/07/1945. In: Biblioteca nacional ${ }^{202}$ Idem Ibidem.

${ }^{203}$ FRAIZ, Priscila e REIS, Eduardo Queiroz. Paulo Carneiro e Casa de Augusto Comte. In: Ciência, Política e Relações Internacionais: ensaios sobre Paulo Carneiro. Rio de Janeiro: editora Fiocruz e UNESCO, 2004, p.69.
} 
Laffitte se tornou, portanto, o maior representante da filosofia e da religião fundadas por Comte, e foi através de um contato com ele, no ano de 1877, que Miguel Lemos, fundador da Igreja Positivista do Brasil, se converteu ao positivismo. A relação entre os dois foi de amizade e cooperação até que, no ano de 1893, Lemos rompeu com o representante francês do positivismo, acusando-o de ser um traidor da filosofia de Comte. De acordo com os autores citados $^{204}$ :

Procurando não só expandir o positivismo, mas também centralizá-lo em sua figura, Miguel Lemos rompeu com Pierre Laffitte em 1883, acusando-o de sofista, ou seja, de trair a filosofia de Comte (IPB, 1881), pois a IPB priorizava a religião positivista e a Sociedade Imobiliária Pierre Laffitte, a filosofia positivista. Desse modo, a IPB considerou os adeptos de Laffitte hereges da religião da humanidade.

No mesmo ano do rompimento entre os dois, Laffitte adquiriu a casa em que Augusto Comte viveu seus últimos anos, iniciando a conservação do imóvel e dos documentos pertencentes a Comte, assim como ele havia determinado em seu testamento. Os positivistas da igreja do Rio de Janeiro, em 1903, resolveram comprar o apartamento em que Clotilde de Vaux viveu, para lá instalar uma capela da humanidade comandada e dirigida por eles. No entanto, por não terem acesso aos documentos que estavam em posse de Laffitte e que indicavam o endereço correto de Clotilde, compraram o imóvel vizinho ao que a musa inspiradora de Comte havia vivido, achando que haviam comprado o apartamento certo. Esse apartamento foi colocado no nome de Otávio Carneiro, da família de Paulo e até então pertencente à igreja, assim como os demais membros da família. Nessa época, os membros da família Carneiro ainda pertenciam à instituição e mantinham uma boa relação com os membros do apostolado positivista do Brasil. O trecho a seguir demonstra essa proximidade ${ }^{205}$ :

Segundo seu próprio depoimento (Carneiro, 1979), Paulo Carneiro nasceu numa família positivista. Seus pais se casaram conforme o rito civil instituído por Comte e o educaram nesse universo. À moda positivista, estudou na casa e na Igreja Positivista, onde recebeu ensinamentos sobre ciências e humanidades diretamente de Cândido Rondon e de Teixeira Mendes, a cujas prédicas dominicais comparecia.

\footnotetext{
${ }^{204}$ Idem Ibidem, p.70.

${ }^{205}$ Idem Ibidem, p. 32.
} 
A mudança na relação entre a Igreja Positivista do Brasil e a família Carneiro começou quando Paulo Carneiro, enviado a Paris em 1927 como bolsista do governo brasileiro para desenvolver uma pesquisa no Instituto Pasteur, foi visitar a casa de Augusto Comte. Ao chegar ao local e encontrá-lo inteiramente desorganizado e mal conservado, Carneiro indagou ao gerente da casa o motivo de tanta desorganização, como o próprio Carneiro relatou ${ }^{206}$ :

Entrei naquela casa, que para mim, formado no meio positivista brasileiro, tinha o valor de um santuário. Ali havia vivido um filósofo, um renovador, que era ao mesmo tempo um líder espiritual, uma espécie de profeta dos tempos novos. Mas achei tudo muito abandonado. Perguntei ao gerente: 'Em que pé estão os arquivos? Já foram inventariados? Já foi publicada uma lista? Onde estão os manuscritos de todas as obras que no testamento ele declara que estão intactos? (...) Insisti sobre a necessidade disso, então ele de repente me disse: 'Nós somos poucos, somos velhos, o senhor quer nos ajudar? ' De repente, por uma espécie de contágio afetivo, intelectual, ofereceram-me a liberdade de ir quando eu quisesse tocar naqueles arquivos, manuscritos, papéis e classificá-los, inventariá-los (...).

Em razão desse convite, Carneiro passou a freqüentar com assiduidade a casa de Comte, ajudando na organização de seus documentos, até que teve acesso às correspondências que eram enviadas à casa de Clotilde, e que continham outro endereço, diferente daquele em que os positivistas acreditavam que ela havia residido. Ao relatar aos positivistas do Rio de Janeiro a sua descoberta, foi rechaçado e acusado de lafitista, "por ter traído o pensamento ortodoxo da instituição” 207.

A esse acontecimento se seguiu o rompimento da família Carneiro com a Igreja Positivista do Brasil, mas não com a filosofia de Augusto Comte ${ }^{208}$ :

Rompido com a IPB, Carneiro concentrou seus esforços na conservação do apartamento de Comte. Diante da ameaça de destruição iminente do prédio, devido a uma reorganização urbanística de Paris, organizou uma campanha internacional e, em dezembro de 1929, obteve o seu tombamento como monumento histórico da França. Em 1930, passou a reconstruir, com a ajuda do inventário judicial recuperado, o apartamento tal e qual Comte o deixara, restaurando os móveis às suas custas, já que a Sociedade Civil Imobiliária se encontrava incapaz financeiramente.

\footnotetext{
${ }^{206}$ Idem Ibidem, p.72-73

${ }^{207}$ Idem Ibidem, p.74.

${ }^{208}$ Idem Ibidem, p.75.
} 
A dedicação de Carneiro ao trabalho de conservação dos pertences e dos manuscritos de Augusto Comte, com a publicação de inéditos do filósofo, a catalogação de todos os seus documentos, o tombamento e a conservação de seu imóvel com recursos próprios, é também bastante semelhante à dedicação de seus professores colegiais, sobretudo de Francisco Venâncio Filho, à memória de Euclides da Cunha. Da mesma maneira que o euclidiano foi incansável na publicação, edição, organização da obra de Euclides e na conservação de seu arquivo, além da publicação por ele de inúmeros livros e artigos sobre o escritor, Carneiro também se engajou em empreendimento semelhante, dessa vez em homenagem a Augusto Comte, como atestam os autores já citados ${ }^{209}$ :

\begin{abstract}
Ele sempre acreditou estar conduzindo uma missão sagrada, à qual não podia se furtar, e à qual deveria consagrar uma parte essencial de sua vida. Penso não estar desvalorizando-o ao dizer que no fundo sua ação na UNESCO e sua ação em prol de Comte configuravam um só e mesmo combate. (4/10/2001)
\end{abstract}

De acordo com o mesmo texto, a criação da Associação Brasileira dos Amigos de Augusto Comte foi uma iniciativa tomada pelo pai de Paulo Carneiro com o objetivo de auxiliar o filho em suas iniciativas pela conservação da obra e do imóvel de Comte. Reunindo positivistas não ortodoxos, a instituição realizava reuniões e utilizava os recursos arrecadados com os associados para financiar as atividades realizadas em Paris por Paulo Carneiro, sempre em benefício da memória de Comte. À sessão inaugural da associação, em julho de mil novecentos e quarenta e cinco, compareceram: Afrânio Peixoto, Venâncio Filho, Professor Paula Lopes, René Descartes de Paula e Jefferson de Lemos ${ }^{210}$. Há, no Boletim da Associação Brasileira dos Amigos de Augusto Comte, de abril de 1947, o relato de uma outra sessão realizada pela Associação na Associação Brasileira de Educação. Da sessão, ocorrida no dia cinco de junho de mil novecentos e quarenta e seis, participaram: Rondon, o embaixador Souza Dantas, Dr. Artur Torres Filho, cel. Augusto de Araújo Dória, Agliberto Xavier, Brício Filho, Edgard Sussekind de Mendonça e Sr. Venâncio de Figueiredo Neiva. O motivo da convocação dessa sessão extraordinária foi o falecimento de Mario Carneiro, no dia anterior. Na ocasião, alguns dos presentes fizeram discursos em homenagem ao idealizador da instituição. Venâncio Filho não pôde estar presente, em razão de uma enfermidade que o levaria a falecer no mesmo ano, mas enviou o seu discurso pelo seu grande amigo, Edgar

\footnotetext{
${ }^{209}$ Idem Ibidem, p.77.

${ }^{210}$ Boletim da Associação Brasileira de Amigos de Augusto Comte. Mario Barboza Carneiro. In memorian. Rio de Janeiro: Jornal do Commercio, 1947.
} 
Sussekind de Mendonça. A seguir, os trechos dos discursos de Edgard Sussekind de Mendonça e Venâncio Filho em homenagem a Mario Carneiro, registrados no boletim citado, confirmam novamente a ligação dos mesmos com a filosofia de Comte ${ }^{211}$ :

Venâncio Filho, não podendo comparecer, por doente, a esta homenagem à memória de Mario Carneiro, pediu-me que lesse as palavras que aqui deveria pronunciar.

Se bem que a sua doença seja infelizmente verdadeira, dir-se-ia que Venâncio Filho quis, com a sua bondade de amigo, - tal a força de que nele é capaz a amizade- proporcionar-me esta oportunidade de declarar em público, junto dele, irmanado a ele, a admiração comum que dedicamos ao homenageado desta tarde. (...) Venâncio como todos nós, positivistas ou não, que aqui nos reunimos em memória de Mário Carneiro, todos somos acordes em reconhecer e proclamar aquilo que o grande morto sempre reconheceu e proclamou durante o colapso republicano de que estamos acabando de ressurgir: que os erros do Brasil oficial de 1891, tão profundamente inspirada no Positivismo, podem ser medidos pelo grau de desrespeito que viemos praticando, ou deixando praticar..., em relação às normas de tolerância espiritual e intransigência cívica que nos ensinou o Positivismo.

Às palavras de Sussekind de Mendonça se seguiram as de Venâncio Filho, lidas por seu amigo e das quais se destacam os trechos abaixo:

O culto por Augusto Comte conservou-se no Brasil, como se sabe, com mais intensidade do que em qualquer outra parte deve-se em conseqüência a brasileiros este culto. Quase toda a vida do filósofo de Montpellier desenrolou-se em Paris, de modo que, é aí que se acham todos os traços de sua grande vida, desde a casa em que viveu até a sepultura. A casa, à rua Mr. le Prince, 10, bem no Quartier Latin, aquele bairro Frances perfumado de uma aura inesquecível de cultura e de passado, foi tornada monumento nacional por esforços brasileiros. ${ }^{212}$

O positivismo pela soma de princípios sadios no domínio filosófico, político e moral, está a exigir uma exposição informada do material acumulado pela ciência nestes últimos 50 anos e pelas conquistas sociais do nosso tempo, especialmente o exame objetivo e sereno desta incorporação do proletariado que se processou na Rússia. Ninguém mais aparelhado pela inteligência, pela cultura e pelo coração, para a realização desta obra, do que este nosso admirável Paulo Carneiro, tão presente a todos nós nesta hora de veneração e de saudade. Toda esta obra benemérita que ele já realizou de

\footnotetext{
${ }^{211}$ Palavras do Professor Edgard Sussekind de Mendonça. In: Boletim da Associação Brasileira de Amigos de Augusto Comte. Mario Barboza Carneiro. In memorian. Rio de Janeiro: Jornal do Commercio, 1947, p. 61-62.

${ }^{212}$ Discurso do Professor F. Venâncio Filho, lido pelo consócio Edgard Sussekind de Mendonça. In: Boletim da Associação Brasileira de Amigos de Augusto Comte. Mario Barboza Carneiro. In memorian. Rio de Janeiro: Jornal do Commercio, 1947, p. 67.
} 


\begin{abstract}
culto e de cultura, teve a inspiração de Mário Carneiro, com o seu conselho, com o seu equilíbrio, com a sua lucidez. Por tudo isso, o varão ilustre que deixou como cidadão o perfil de uma vida exemplar, estimulando o desenvolvimento de uma doutrina filosófica, baseada nos mais nobres sentimentos, merece o respeito e a veneração de quantos no Brasil aspiram por um mundo melhor de paz e de fraternidade. ${ }^{213}$
\end{abstract}

Os trechos acima confirmam não apenas a relação dos principais euclidianos com a família Carneiro e, sobretudo, com Paulo Carneiro, mas também a relação dos mesmos com o positivismo. De acordo com o que foi levantado a respeito da citada Associação, o presidente Mario Carneiro foi substituído, após a sua morte, por Trajano Carneiro, um de seus filhos. Não há, nas fontes consultadas, informações sobre o período em que a associação continuou a existir e sobre o ano em que ela chegou ao fim.

De acordo com o que foi pesquisado, a militância dos euclidianos na associação em homenagem a Augusto Comte não parece ter tido a intensidade daquela em homenagem a Euclides. O único que parecia levar adiante um ritual de adoração a Comte similar ao euclidiano era Paulo Carneiro, como já foi dito. No entanto, a presença dos principais euclidianos na associação, a participação ativa de alguns deles e a contribuição pecuniária dada por eles, assim como pelos outros associados, com o objetivo de conservar o imóvel e a obra de Comte atestam a ligação dos mesmos com a filosofia da humanidade.

Entretanto, a grande ligação que possuíam os intelectuais estudados, que foi constante durante as suas vidas e resultou, com o passar dos anos, na consolidação do nome de Euclides entre os maiores escritores nacionais e entre os positivistas foi, certamente, com Euclides da Cunha e com o Grêmio criado em sua homenagem.

No próximo capítulo, a criação do Grêmio Euclides da Cunha de São José do Rio Pardo será abordada em mais detalhes, além da relação de amizade e cooperação existente entre os dois grêmios e das discussões na imprensa carioca acerca de quem seria o maior escritor da nação. Por fim, será analisada a atividade persistente dos dois grêmios Euclides da Cunha e sua relação com a invenção da tradição rio-pardense.

\footnotetext{
${ }^{213}$ Idem Ibidem, p. 69.
} 


\section{CAPÍTULO III: O crescimento da popularidade de Euclides da Cunha nas décadas de 30 e 40: contribuições da militância euclidiana}

\subsection{A criação e a consolidação do Grêmio Euclides da Cunha de São José do Rio Pardo}

Ao longo deste trabalho, a cidade de São José do Rio Pardo já foi citada em diversas ocasiões: essa foi a cidade eleita pelos euclidianos como a "Meca do Euclidianismo", foi nessa cidade que Euclides da Cunha escreveu "Os Sertões” e foi nessa cidade que os euclidianos do Rio de Janeiro conseguiram realizar, juntamente com seus colegas de São Paulo, as homenagens que, para eles, Euclides merecia.

A ligação de Euclides da Cunha com a cidade de São José do Rio Pardo surgiu quando Euclides, que até então trabalhava como engenheiro civil e jornalista, foi chamado a reconstruir a ponte da cidade, que havia ruido. Em 1898 Euclides se mudou para o local, onde permaneceu pelos três anos seguintes e onde deu início ao trabalho que, anos mais tarde, seria considerado uma das principais obras da literatura brasileira: “Os Sertões”. Na cidade, Euclides da Cunha fez amizade com alguns rio-pardenses, sobretudo com o intendente da cidade, Francisco Escobar. A amizade entre os dois e o papel de Escobar como colaborador de Euclides na época em que ele escrevia “Os Sertões” era sempre ressaltada pelos euclidianos da cidade. José Honório de Silos, que foi um dos principais líderes da agremiação paulista, escreveu sobre a ligação entre os dois na Revista do Grêmio Euclides da Cunha do Rio de Janeiro. Em artigo intitulado “Reminiscências de Euclides da Cunha- Francisco Escobar”, o euclidiano afirmou que:

Reconhecido a seus insignes préstimos e sua inigualável amizade, em uma das cartas a Escobar, o grande escritor diz que o seu amigo 'foi um dos melhores colaboradores' de sua obra.

E, realmente o foi; no ponto de vista que mais de uma vez tenho debatido. Sem a dedicação, sem a amizade fraternal de Escobar, sem o seu apoio moral e social, em São José do Rio Pardo nunca brotaria A IDÉIA FORÇA 
DA MENTALIDADE BRASILEIRA, a obra literária, que é considerada A BÍBLIA DA BRASILIDADE. "214

Regina Abreu também menciona, em seu trabalho, a amizade de Euclides com habitantes de São José do Rio Pardo e de cidades vizinhas. É dessa amizade que surgirá, após a morte trágica do escritor, o movimento de culto e homenagem a ele na cidade do interior de São Paulo. Segundo Abreu ${ }^{215}$ :

Os primeiros euclidianos, amigos de Euclides de São José do Rio Pardo, eram, entre outros, Francisco Escobar, Jovino de Silos, Adalgizo Pereira, José Honório, Dr. Pedro de Aquino. A esses vieram juntar-se intelectuais das cidades próximas, que também tinham conhecido o escritor: Valdomiro Silveira e Lafayette de Toledo, de Casa Branca, e Humberto de Queiroz, de Mococa. As trajetórias dos primeiros euclidianos revelam que, em sua maioria, eles eram intelectuais locais que se destacavam em São José do Rio Pardo ou em municípios vizinhos. Quando Euclides desembarcou em São José, muitos fizeram questão de conhecer o engenheiro que lá chegava para reparar uma ponte, pelo fato de já terem lido seus artigos sobre Canudos em O Estado de São Paulo. Euclides recorreu a alguns deles para suas pesquisas, originando-se daí a amizade.

Em 1901, quando Euclides da Cunha deixou a cidade de São José do Rio Pardo, já com a ponte metálica reconstruída, o esboço inicial de “Os Sertões” já estava concluído. A primeira edição do livro foi lançada em 1902, e o sucesso da publicação encheu de orgulho seus companheiros de Rio Pardo $^{216}$, entre eles Escobar, que manteve contato através de correspondência com o escritor mesmo após o fim de sua estada em São José do Rio Pardo ${ }^{217}$.

A morte repentina do escritor, em 1909, também entristeceu os amigos deixados por Euclides na cidade do interior de São Paulo ${ }^{218}$. Mas foi no ano de 1912 que se iniciou na cidade a primeira romaria em homenagem ao escritor. De acordo com o texto "Casa de Cultura Euclides da Cunha”, situado no sítio da Casa Euclidiana de Rio Pardo ${ }^{219}$ :

Pode-se afirmar que elas tiveram início na primeira romaria realizada em 15 de Agosto de 1912 por um grupo de admiradores do escritor que se

\footnotetext{
${ }^{214}$ SILOS, José Honório de. Reminiscências de Euclides da Cunha- Francisco Escobar. In: Revista no Grêmio Euclydes da Cunha. Rio de Janeiro: ago 1939.

${ }^{215}$ ABREU, Regina. O enigma de Os Sertões. Rio de Janeiro, Rocco, 1988, p. 313.

${ }^{216}$ VENTURA, Roberto. Euclides da Cunha: Esboço Biográfico. São Paulo, Cia das Letras, 2003.

${ }^{217}$ Revista do Grêmio Euclydes da Cunha. Rio de Janeiro: ago 1939.

${ }^{218}$ Idem Ibidem.

${ }^{219}$ Casa de Cultura Euclides da Cunha. Disponível em:

http://www.casaeuclidiana.org.br/texto/ler.asp?Id=1243\&Secao=111. Acesso em Dezembro/2009.
} 
reuniu para 'recordar o amigo ausente' no recanto que mais evocava a presença de Euclides da Cunha em São José do Rio Pardo: a ponte, a cabana e o rio; era o começo de um culto jamais rompido.

Regina Abreu cita, em seu livro, o reconhecimento do movimento rio-pardense em homenagem a Euclides por parte de Venâncio Filho. De acordo com a autora ${ }^{220}$ :

Em seu artigo, Venâncio Filho lembrava ainda que a adesão dos paulistas ao euclidianismo se fazia também numa outra cidade que, desde o ano de 1912, vinha cultuando 'com devoção rara, a memória de Euclides da Cunha': São José do Rio Pardo, onde Euclides tinha escrito o livro consagrado durante a construção da ponte que havia ruído sobre o Rio Pardo. Venâncio Filho relatava as homenagens que anualmente eram prestadas ao escritor naquela cidade, 'ponto obrigatório de passagem para fotógrafos e artistas, sob a sombra da mesma paineira e outras árvores que ele mesmo plantou'. Na cabana havia sido colocada sua mesa de trabalho, doada pelo Dr. Jovino de Sylos, que a guardava desde o dia em que Euclides deixou a cidade. Venâncio Filho relatava que 'no recanto deste ambiente euclidiano lindamente ajardinado', naquele mesmo ano, no dia 18 de maio, havia sido inaugurada uma herma em bronze, rememorando a passagem do escritor por São José do Rio Pardo.

No ano de 1918 as homenagens a Euclides em Rio Pardo foram intensificadas com a inauguração, por Vicente de Carvalho, de um medalhão de bronze com a efígie de Euclides. Nos anos subseqüentes, as medidas em homenagem ao escritor aumentaram ainda mais, como está relatado no texto “Casa de Cultura Euclides da Cunha” ${ }^{221}$ e no de Regina Abreu ${ }^{222}$ :

Comemorando o $17^{\circ}$ aniversário da ponte, Vicente de Carvalho inaugurou em 18 de maio de 1918 o medalhão de bronze com a efígie de Euclides, fixado em bloco de granito rosa. Em 15 de Agosto de 1925 foi instituído o feriado municipal 'Dia de Euclides'. No mesmo ano, em 14 de novembro, foi criado o Grêmio Euclides da Cunha, formado por 22 sócios, entre eles 7 participantes da $1^{a}$ romaria. Em 1936 as comemorações passaram a ser organizadas pela Comissão de Festejos Euclidianos nomeada pelo prefeito Dr. Luiz Gonçalves Jr. E presidida pelo Dr. Agripino Ribeiro da Silva e secretariado pelo Dr. Oswaldo Galotti.

O culto rio-pardense à memória do grande escritor começou a revestir-se de um caráter popular e cívico, quando a 18 de maio de 1918, aniversário da inauguração da ponte metálica, foi erguido, na praça lindamente ajardinada, onde fica a choupana, o monumento em que está gravada uma placa de bronze com a imagem votiva do escritor. O monumento foi inaugurado pelo poeta e euclidiano Vicente de Carvalho.

\footnotetext{
${ }^{220}$ ABREU, Regina. O enigma de Os Sertões. Rio de Janeiro, Rocco, 1988, p. 309.

${ }^{221}$ Casa de Cultura Euclides da Cunha. Disponível em:

http://www.casaeuclidiana.org.br/texto/ler.asp?Id=1243\&Secao=111. Acesso em Dezembro/2009
}

${ }^{222}$ ABREU, Regina. O enigma de Os Sertões. Rio de Janeiro, Rocco, 1988, p. 317. 
Foi também a partir do ano de 1918 que os admiradores de Euclides da Cunha do Rio de Janeiro e do estado de São Paulo passaram a manter um intenso contato e cooperação. A conferência de Roquette-Pinto realizada na capital, com o objetivo de angariar fundos para o Grêmio do Rio de Janeiro, já havia entusiasmado alguns intelectuais paulistanos, como foi relatado no capítulo anterior. A esses intelectuais paulistanos juntaram-se aqueles do interior do estado, que conheceram pessoalmente o escritor e já realizavam homenagens a ele em suas cidades. Nessa relação de proximidade entre os intelectuais dos dois estados, a atuação de Venâncio Filho foi fundamental, como atesta o texto sobre a Casa de Cultura Euclides da Cunha, já citado ${ }^{223}$ :

O sucesso da primeira Semana (euclidiana), que contou com a participação de 6 conferencistas ilustres, entre eles o Prof. Francisco Venâncio Filho, que foi o elo de ligação entre São José do Rio Pardo e intelectuais do Rio de Janeiro (...)

Mas foi nas décadas de 30 e 40 que o movimento euclidiano em Rio Pardo se estruturou, com apoio dos euclidianos do Rio de Janeiro e do governo Vargas ${ }^{224}$. Nesse período, surgiram as Semanas Euclidianas, em 1935, a maratona intelectual sobre Euclides da Cunha, em 1939, e a Casa de Cultura Euclides da Cunha, criada em 1946, no local onde o escritor havia morado com sua família. Além disso, foi nessa época que a cabana em que Euclides escreveu “Os Sertões" foi transformada em Patrimônio Histórico Nacional. ${ }^{225}$ A respeito da Casa Euclidiana, afirma Abreu $^{226}$ :

A Casa Euclidiana, nesse contexto, emergiu como um misto de museu e arquivo do escritor e antiquário da cidade. E foi a partir de sua criação, enquanto lugar de memória oficial, legitimado pelo governo do Estado de São Paulo, que pagava funcionários exclusivos, que o euclidianismo se institucionalizou definitivamente.

Dessa forma, e ao contrário do que ocorria com o Grêmio do Rio de Janeiro, o Grêmio de São José do Rio Pardo crescia cada vez mais, com apoio dos habitantes da cidade, dos governos municipal e federal e dos euclidianos cariocas. O entusiasmo rio-pardense por Euclides e sua obra era freqüentemente elogiado pelos euclidianos do Rio de Janeiro que, ao mesmo tempo,

\footnotetext{
${ }^{223}$ Casa de Cultura Euclides da Cunha. Disponível em:

http://www.casaeuclidiana.org.br/texto/ler.asp?Id=1243\&Secao=111. Acesso em Dezembro/2009, p.1.

${ }^{224}$ ABREU, Regina. O enigma de Os Sertões. Rio de Janeiro, Rocco, 1988.

${ }^{225}$ Idem Ibidem.

${ }^{226}$ Idem Ibidem, p. 336.
} 
lamentavam que o mesmo não ocorresse na Capital Federal ${ }^{227}$. Por outro lado, embora o Grêmio do Rio de Janeiro não tivesse em sua cidade a popularidade que o Grêmio paulista possuía, a rede de relações dos euclidianos cariocas e as posições de destaque que eles ocupavam no cenário político nacional foram fundamentais para a maior popularização, em âmbito nacional, do Grêmio do interior paulista. No mesmo texto já citado, sobre a Casa de Cultura Euclides da Cunha, Venâncio Filho é apontado como o responsável por conseguir transformar a Cabana em que Euclides escreveu “Os Sertões” em patrimônio histórico: ${ }^{228}$ “O presidente Getúlio Vargas, em 1938, pelo decreto número 25, incorporou a Cabana ao Patrimônio Histórico Nacional, atendendo ao pedido do Prof. Francisco Venâncio Filho.”

As Semanas Euclidianas, criadas em 1935, também contaram com ativa participação dos euclidianos cariocas. Sobre esse evento, afirma Regina Abreu ${ }^{229}$ :

Em 1935, dois paulistas decidiram criar novos eventos, contribuindo decisivamente para a consolidação das comemorações em torno da figura de Euclides da Cunha em São José do Rio Pardo. Um médico, dr. Oswaldo Galotti, então com 34 anos, instituiu as 'semanas euclidianas'(...)

Uma das tradições do evento era convidar, a cada ano, um intelectual de renome nacional para que proferisse uma conferência sobre o escritor. Com a ampliação do evento, após a instituição das 'semanas' e das 'maratonas euclidianas', a conferência tornou-se o ponto alto, com a presença de grandes personalidades e renomados intelectuais da cidade.

Nas primeiras Semanas Euclidianas, a maioria dos conferencistas oficiais eram aqueles vindos do Rio de Janeiro que, ou eram pertencentes ao Grêmio do Rio de Janeiro, ou eram levados por intermédio dos euclidianos residentes naquela cidade ${ }^{230}$. Podemos citar, entre os conferencistas das primeiras Semanas, Roquette-Pinto (1937), Francisco Venâncio Filho (1939), Afonso Arinos de Mello Franco (1940), Alberto Rangel (1942), Afrânio Peixoto (1943) e Raja Gabaglia (1945) ${ }^{231}$. Além disso, nesses anos iniciais, quem corrigia os trabalhos dos alunos inscritos na Maratona Intelectual Euclides da Cunha e determinava o seu vencedor era Edgard Sussekind de Mendonça, presidente do Grêmio Euclides da Cunha do

\footnotetext{
${ }^{228}$ Casa de Cultura Euclides da Cunha. Disponível em:

http://www.casaeuclidiana.org.br/texto/ler.asp?Id=1243\&Secao=111. Acesso em Dezembro/2009.

${ }^{229}$ ABREU, Regina. O enigma de Os Sertões. Rio de Janeiro, Rocco, 1988.p. 320.

${ }^{230}$ Idem Ibidem.

${ }^{231}$ Idem Ibidem. p. 360.
} 
Rio de Janeiro. ${ }^{232}$ Coincidentemente ou não, foi nas décadas de 30 e 40, em que o Grêmio paulista encontrava apoio no do Rio de Janeiro, que, de acordo com Regina Abreu, o movimento ganhou mais notoriedade ${ }^{233}$.

Em correspondência de 1940 endereçada ao presidente da Comissão de Festejos Euclidianos, Sussekind de Mendonça, mais uma vez, lamenta o insucesso das iniciativas em homenagem a Euclides na cidade do Rio de Janeiro e faz elogios aos companheiros de São José do Rio Pardo $^{234}$ :

Tendo recebido, por gentileza de um amigo do grêmio Euclides da Cunha, Dr. Mário de Góes Calmon de Brito, as publicações relativas a mais uma das nobres comemorações com que o berço de Os Sertões vem cada ano merecendo mais o título que, de há muito, lhe deram os euclidianos do Rio de Janeiro de 'Meca do Euclidianismo', é com a profunda comunhão de sempre que, em nome daquele grêmio, peço-vos transmitir aos euclidianos de São José do Rio Pardo o nosso abraço fraternal.

Também aqui, somadas às tristes contingências do momento a perturbadora situação de capital política de um país que ainda não compreende que a sua salvação está nos postulados da obra euclidiana. O culto do Mestre não sofreu interrupção. Para não se confundir com outras cultuações imediatistas, o Grêmio, não contando com o ambiente de uníssono carinho e nobilíssima compreensão que circunda, às margens do Rio Pardo, a 'barraquinha d'os Sertões' a cada 15 de Agosto pede guarida a uma instituição de pura cultura, e relembra o seu patrono, declarando sempre ao pequeno público que lhe assiste que, naquele mesmo instante, Euclides recebe a sua mais expressiva consagração, que é uma vida de toda uma cidade, bem no coração do Brasil, que pulsa uma semana inteira concentrando-se num único gesto, vibrando num só pensamento, nessa pletora que são as comemorações euclidianas de São José do Rio Pardo. Este ano, foi na Academia Carioca de Letras que tivemos ocasião de comemorar Euclides, e declarar em público, como sempre, a nossa fraternal comunhão com os euclidianos dessa cidade paulista, tão genuinamente brasileira (não fosse ela paulista...), que a comissão que presidis dignamente representa.

Euclides da Cunha, bem o sabeis, não é glória que se baste de um monumento, gigantesco embora, na capital do país. O Grêmio Euclides da Cunha, que o reclama da consciência nacional, mas que não o deseja decretado prefere adiá-lo e vem persistentemente repetindo que as comemorações a cada 15 de Agosto devem tomar a alta significação de um ante-monumento, alicerce da compreensão democrática que receberá em melhores dias a efígie do mais brasileiro dos nossos concidadãos.

\footnotetext{
${ }^{232}$ Arquivo Euclides da Cunha. Série 7 Código de referência: BR ABL AA EC gec. In: Academia Brasileira de Letras.

${ }^{233}$ ABREU, Regina. O enigma de Os Sertões. Rio de Janeiro, Rocco, 1988.

${ }^{234}$ Arquivo Euclides da Cunha. Série 7 Código de referência: BR ABL AA EC gec. In: Academia Brasileira de Letras.
} 
Que melhor contribuição para esse ante-monumento de compreensão da vida e da obra euclidiana que a 'Semana Euclides', engastada no ouro da lei da região mais progressista da pátria?

Acreditai, Sr. Presidente da comissão de festejos euclidianos, no entusiasmo do Grêmio Euclides da Cunha do Rio de Janeiro, diante do que São José do Rio Pardo vem insubstituivelmente realizando em bem do ideal de cultura e brasilidade que é o ideal de todos os euclidianos. (Presidente do Grêmio Euclides da Cunha)

Nas revistas do Grêmio Euclides da Cunha do Rio de Janeiro, entre 1935 e 1939, havia sempre um artigo exaltando as qualidades da cidade e do movimento de São José do Rio Pardo. Na revista de 1939 há um pequeno texto, intitulado "S. José do Rio Pardo" ${ }^{235}$, em que se lê:

Cada ano que passa São José do Rio Pardo, justamente apelidada de Meca do Euclidianismo, amplia as suas homenagens ao seu grande Nome. Não basta o carinho que conserva a relíquia do ranchinho de "Os Sertões", sob a mesma linda palmeira. Não basta a reverência com o que ergueu o monumento que a palavra amiga e evocativa de Vicente de Carvalho inaugurou a 18 de Maio de 1918, décimo sétimo aniversário da ponte que conserva nas suas vigas a placa de gratidão. Não basta o feriado municipal que faz de 15 de Agosto data magna da cidade. Não basta o nome dado à vila situada na outra margem de Euclides da Cunha.

Nada disto basta àquela gente heróica, que dá com esta atitude um exemplo ao Brasil, porque criou uma tradição, hoje que já há poucos dos gloriosos companheiros daqueles dias de 1898 a 1901. E esta tradição não morrerá, porque cada dia mais vai-se enraizando no coração do povo e na veneração das gerações que surgem.

Este ano há dois fatos memoráveis a assinalar.

Primeiro o ato do Patrimônio Artístico e Histórico Nacional tornando o recanto euclidiano monumento nacional, por deliberação da nobre inteligência de Rodrigo Mello Franco de Andrada, que põe toda a sua cultura e a sua sensibilidade artística a serviço de uma grande obra patriótica.

Segundo a inauguração de uma placa recordando a memória de Francisco Escobar cuja presença junto à glória de Euclides estava tardando e que, num ato de justiça, São José do Rio Pardo hoje realiza.

Não é possível portanto, aos euclidianos e deveram ser todos os brasileiros, deixar de volver nesta hora os olhos e corações para a pequena cidade de São Paulo que dá ao Brasil um exemplo sem par de civismo, de justiça e de grandeza humana, na glorificação permanente de um de seus Grandes Euclides da Cunha.

\footnotetext{
${ }^{235}$ S. José do Rio Pardo. In: Revista do Grêmio Euclydes da Cunha. Rio de Janeiro: ago 1939.
} 
Esses artigos elogiosos também continham, freqüentemente, críticas à situação do Rio de Janeiro, onde o Grêmio não encontrava a mesma acolhida ${ }^{236}$. Dessa maneira, os dois grêmios, do Rio de Janeiro e do Rio Pardo, pareciam se complementar: enquanto o do Rio de Janeiro possuía intelectuais renomados, que podiam contribuir para conferir maior importância ao movimento paulista, o de São José do Rio Pardo possuía a popularidade e o entusiasmo de uma cidade inteira, que faltavam ao grêmio carioca. Apoiar o Grêmio de São José do Rio Pardo parecia ser, para os euclidianos do Rio de Janeiro, uma forma de ver realizados seus desejos, que não puderam ser inteiramente concretizados na capital do país, como confirma Regina Abreu ${ }^{237}$ :

\begin{abstract}
O movimento euclidiano, iniciado no Rio de Janeiro, encontrava em São Paulo, especialmente em São José do Rio Pardo, sua sede definitiva. O projeto dos primeiros euclidianos de construir um monumento em bronze ficou no papel. A imagem de um Euclides à beira-mar, fixada num dos morros emblemáticos da cidade do Rio de Janeiro, foi definitivamente suplantada pela imagem de um Euclides doublé de engenheiro e escritor numa cabana às margens de um pequeno rio de uma cidade do interior paulista.
\end{abstract}

Desse modo, apesar de serem grêmios diferentes, houve uma relação de troca intensa entre os membros do Grêmio Euclides da Cunha do Rio de Janeiro e de São José do Rio Pardo, que acabou tornando os dois grêmios muito semelhantes na maneira de homenagear e glorificar o seu maior ídolo. Entretanto, enquanto o Grêmio do Rio de Janeiro teve, desde o início, uma forma de homenagear Euclides da Cunha muito similar à forma como os positivistas homenageiam seus vultos, o movimento de São José do Rio Pardo foi adquirindo essas características ao longo dos anos. Em sua fase inicial, o movimento de Rio Pardo era apenas uma reunião de amigos do escritor desejando lhe prestar uma homenagem ${ }^{238}$. A criação de um Grêmio em homenagem a Euclides da Cunha, o tombamento de sua cabana, a instituição do 15 de Agosto como feriado municipal, a criação das Semanas Euclidianas e da Casa de Cultura Euclidiana, que marcam a passagem de uma simples homenagem para um ritual constante e intenso de adoração, similar ao movimento do Rio de Janeiro, acontecem apenas após a década de 20, quando os membros dos dois Grêmios já estão em permanente contato. Desse modo, embora não seja minha intenção afirmar que os principais euclidianos de São José do Rio Pardo também fossem positivistas, a relação de troca existente entre os dois

\footnotetext{
${ }^{236}$ Revista do Grêmio Euclydes da Cunha. Rio de Janeiro: 1935- 1939.

${ }^{237}$ ABREU, Regina. O enigma de Os Sertões. Rio de Janeiro, Rocco, 1988, p. 337.
} 
grêmios e a importância que os euclidianos do Rio de Janeiro tiveram na divulgação e nacionalização do movimento de Rio Pardo me faz crer que, com o passar dos anos, as propostas e idéias iniciais do Grêmio do Rio de Janeiro, que não obtiveram o apoio popular necessário e por isso não foram inteiramente implementadas na capital do país, encontraram receptividade em São José do Rio Pardo, tornando os rituais rio-pardenses similares aos cariocas e, por conseqüência, aos positivistas. Uma frase de José Honório de Silos, presidente do Grêmio paulista, escrita em correspondência para o presidente do Grêmio carioca atesta, mais uma vez, a proximidade e identidade de projetos entre os grêmios ${ }^{239}$ : "Desejo mesmo um contato freqüente com os euclidianos daí. Assim, mais facilmente, realizaremos os ideais de Venâncio- a glorificação de Euclides”.

Algumas das similaridades dos rituais do Grêmio de São José do Rio Pardo com o positivismo, como o apelido de “Meca do Euclidianismo” que a cidade paulista possuía e as articulações para o tombamento da cabana de Euclides, foram realizações dos euclidianos do Rio de Janeiro, demonstrando o papel que esses intelectuais tiveram na mudança da forma como os rio-pardenses homenageavam o escritor e, conseqüentemente, na semelhança entre essas homenagens e aquelas promovidas pelos positivistas aos seus Vultos da Humanidade.

\subsubsection{O papel do Estado Novo no fortalecimento do Grêmio Euclides da Cunha de S. José do Rio Pardo}

Segundo Regina Abreu ${ }^{240}$, o movimento de glorificação de Euclides da Cunha de São José do Rio Pardo, embora criado anteriormente, chegou a seu ápice nas décadas de 30 e 40 . Foi nessa época que o Grêmio paulista passou a receber subvenções do governo do Estado de São Paulo e teve sua sede situada em São José do Rio Pardo, transformada em Meca do Euclidianismo, titulação que, como mencionado anteriormente, foi dada a este grêmio pelos euclidianos do Rio de Janeiro. Ainda de acordo com a autora, esse reconhecimento do Grêmio paulista por parte de intelectuais e políticos teria ocorrido também graças às afinidades entre a ideologia

\footnotetext{
${ }^{238}$ Casa de Cultura Euclides da Cunha. Disponível em:

http://www.casaeuclidiana.org.br/texto/ler.asp?Id=1243\&Secao=111. Acesso em Dezembro/2009.

${ }^{239}$ Arquivo Euclides da Cunha. Série 7 Código de referência: BR ABL AA EC gec. In: Academia Brasileira de Letras.

${ }^{240}$ ABREU, Regina. O enigma de Os Sertões. Rio de Janeiro, Rocco, 1988.
} 
do Estado Novo e o pensamento euclidiano. No entanto, embora também reconheça a afinidade citada pela autora, acredito que ela teve menos importância na glorificação de Euclides do que afirma Regina Abreu.

De acordo com a autora ${ }^{241}$ :

Durante o período do Estado Novo (1937-1945), o movimento euclidiano de São José do Rio Pardo passou a receber verba do governo do Estado de São Paulo, possibilitando a institucionalização definitiva das 'Semanas Euclidianas'. Segundo o pesquisador e 'cronista da cidade'. Rodolpho del Guerra, 'a verba era boa, dava p'ra manter os eventos'. Além disso, a população da cidade participava de forma definitiva, recebendo os conferencistas $e$ as pessoas que chegavam de fora em suas próprias residências. Era o auge do movimento euclidiano. $O$ culto ao escritor em São José do Rio Pardo coincidia com um momento político em que o governo federal tinha entre suas principais metas a virada para o interior, visando a colonizar regiões ainda pouco exploradas. Essa meta foi desenvolvida por Cassiano Ricardo, um dos ideólogos do Estado Novo, num livro intitulado A Marcha para o Oeste. Euclides da Cunha foi tomado como símbolo da 'tradição de bandeirar, e Os Sertões, como roteiro para os 'bandeirantes modernos' do Estado Novo.

Desse modo, para Regina Abreu, assim como em Euclides, a idéia de integrar os dois Brasis tão díspares seria fundamental para ideólogos do governo de Vargas. Daí a valorização da figura do Euclides bandeirante, que se recusou a produzir uma literatura inspirada em moldes franceses e foi até o coração do Brasil retratar o sertanejo, cerne da nacionalidade ${ }^{242}$. Para ela, isso explicaria também o apoio dos paulistas, já que essa era uma forma de valorizar a contribuição do bandeirante e do paulista na história nacional. Sobre o apoio de São Paulo aos movimentos em homenagem a Euclides, afirma Regina Abreu ${ }^{243}$ :

A adesão do 'Estadão' sinalizava também outra característica. As elites paulistas reiteravam o 'espírito bandeirante'. Por intermédio de um jornal paulista, o escritor fora enviado a Canudos; numa cidade paulista, concluíra o grande trabalho redentor da nacionalidade. São Paulo mais uma vez adiantava-se, fundando e patrocinando a memória do grande escritor. Em 1925, a Câmara Municipal aprovou projeto de lei instituindo o dia 15 de Agosto feriado municipal em São José do Rio Pardo. A partir de então, a cidade passou a ter dói feriados: o dia 19 de março, data de fundação da cidade, e o dia 15 de agosto, data da morte de Euclides da Cunha.

\footnotetext{
${ }^{241}$ Idem Ibidem, p. 320-321.

${ }^{242}$ Idem Ibidem.
} 
Considero que houve, de fato, uma relação entre os ideais nacionalistas e integracionistas do Estado Novo e a figura de Euclides da Cunha, e prova disso são as visitas e contribuições na forma de artigos ao Grêmio, até mesmo aquele situado no Rio de Janeiro, por parte de intelectuais nacionalistas como Plínio Salgado, Cassiano Ricardo até mesmo Gilberto Freire, que não era considerado nacionalista, mas escreveu artigos elogiando a integração do sertanejo ao panorama nacional feita pela obra de Euclides da Cunha ${ }^{244}$. A idéia de aproximar a conduta de Euclides à de um bandeirante também apareceu em artigos de outros escritores, como o de Lúcia Miguel Pereira ${ }^{245}$, publicado na revista do Grêmio Euclides da Cunha do Rio de Janeiro e intitulado “Euclides da Cunha Bandeirante”. Nesse artigo, a autora diz: “Mesmo sem Os Sertões, Euclides da Cunha seria um grande escritor, e teria direito à nossa admiração. Com Os Sertões, foi mais: foi grande brasileiro, e merece a nossa comovida gratidão.” 246

No entanto, boa parte das medidas citadas por Abreu como evidência da contribuição do governo federal para a glorificação de Euclides foram tomadas pelos euclidianos e positivistas do Rio de Janeiro, que ocupavam postos de destaque no governo federal. Segundo a autora ${ }^{247}$ :

(...) o governo federal empenhou-se em divulgar a biografia e a obra de Euclides da Cunha. Veículos oficiais do governo, como o Instituto Nacional do Cinema Educativo (Ince) e o jornal A Manhã, encarregaram-se dessa tarefa.

Como vimos, a criação do Ince contou com a participação ativa de Roquette-Pinto e Venâncio Filho. A proposta de criação do Instituto foi de autoria de Roquette-Pinto e os filmes sobre Euclides produzidos no instituto foram produzidos por ele e narrados por Venâncio Filho ${ }^{248}$. As outras medidas citadas por Regina Abreu como sendo do governo federal, como a criação da sala Euclides da Cunha no Museu Nacional, a inclusão da literatura de Euclides nos currículos escolares e a inclusão de livros do autor e sobre ele na Coleção Brasiliana também foram tomadas pelos euclidianos citados acima, que o fizeram por meio de seus cargos e seu

\footnotetext{
243 Idem Ibidem, p. 319.

${ }^{244}$ Revista do Grêmio Euclydes da Cunha. Rio de Janeiro: ago 1919. Revista do Grêmio Euclydes da Cunha. Rio de Janeiro: ago 1935. Revista do Grêmio Euclydes da Cunha. Rio de Janeiro: ago 1936. .Revista no Grêmio Euclydes da Cunha. Rio de Janeiro: ago 1937. .Revista no Grêmio Euclydes da Cunha. Rio de Janeiro: ago 1939.

${ }^{245}$ PEREIRA, Lúcia Miguel. Euclides da Cunha Bandeirante. IN Revista do Grêmio Euclydes da Cunha. São José do Rio Pardo: ago 1935.

${ }^{246}$ Idem. Ibidem.

${ }^{247}$ ABREU, Regina. O enigma de Os Sertões. Rio de Janeiro, Rocco, 1988, p.321.

${ }^{248}$ Idem Ibidem.
} 
relacionamento com autoridades do campo educacional e editorial brasileiro ${ }^{249}$. Tanto Francisco Venâncio Filho quanto Edgard Sussekind de Mendonça e Roquette-Pinto, que foram os principais autores das medidas citadas por Abreu e que, segundo ela, contribuíram de maneira substancial para enraizar Euclides no posto de clássico da literatura nacional, davam maior destaque à identidade do escritor com a literatura científica nos seus escritos, e pouco diziam sobre o chamado "Euclides bandeirante”. Havia nos escritos dos euclidianos do Rio de Janeiro um tom predominante de valorização das características científicas de Euclides, como já foi dito nos capítulos anteriores.

As afirmações abaixo, de autoria de Roquette-Pinto e Venâncio Filho, demonstram novamente a valorização dada pelos euclidianos do Rio de Janeiro à ciência na obra de Euclides:

Os Sertões não é um livro de literatura: é um livro de ciência e fé. E são essas as duas molas que faltam para o desencadear da nossa cultura popular: crer e aprender! (...) E quando o desânimo te infiltrar o coração, procura Euclides, ele te mostrará, com verdade e fulgor, o mundo de que és dono. ${ }^{250}$

(...) é incontestável uma estrutura científica, informando toda a obra de Euclides da Cunha, sobretudo Os Sertões.

(...) Encontra-se, no grande livro, uma linha de composição científica, espécie de espinha dorsal, em torno da qual todo o contexto da obra de articula, lógica e metodicamente. ${ }^{251}$

Portanto, embora haja, de fato, uma proximidade entre os ideais integracionistas do governo Vargas, sobretudo do Estado Novo, e as idéias expostas por Euclides em seu livro de maior destaque, considero que o apoio do governo federal ao movimento de valorização de Euclides da Cunha se deveu mais à militância dos intelectuais estudados neste trabalho do que à valorização do Euclides bandeirante, como propõe Regina Abreu. Considero também, com base em tudo o que já foi exposto neste trabalho, que a principal identidade destacada pelos euclidianos do Rio de Janeiro era a de Euclides com a ciência, embora eles também escrevessem sobre as inúmeras outras qualidades da obra literária e do caráter do escritor.

\footnotetext{
${ }^{249}$ Idem Ibidem.

${ }^{250}$ ROQUETTE-PINTO, Edgard. “Euclides da Cunha naturalista”. IN Seixos rolados: Estudos brasileiros. São Paulo: Editora Nacional, 1927, p. 300.
} 
Como intelectuais ligados ao conhecimento científico, seja como acadêmicos, seja como professores, Roquette-Pinto, Venâncio Filho e Sussekind de Mendonça defendiam a superioridade da literatura de cunho científico em relação a outros modelos literários, como será possível perceber no item que analisa a polêmica que se estabeleceu nos meios intelectuais acerca de quem seria o maior escritor nacional.

A elevação de Euclides da Cunha ao status de maior escritor nacional de alguma forma ajudaria a consolidar um padrão de literatura mais afeito a uma postura científica do que aquele que tinha em Machado de Assis o seu maior exemplo.

A insistência deste trabalho no nome de Machado de Assis, como símbolo de um modelo de literatura distinto do de Euclides da Cunha, também não é pura coincidência: a comparação entre os dois era recorrente entre os críticos literários da época ${ }^{252}$. Ainda que Euclides da Cunha não tenha tomado o lugar de maior escritor nacional de Machado de Assis, a discussão se instalou nos meios literários, o que talvez tenha sido por si só, um sucesso da militância euclidiana. Mas, pode-se perguntar, como esses intelectuais contribuíram, de fato, para a construção do mito euclidiano? Além do próprio fortalecimento do Grêmio Euclides da Cunha, esses intelectuais conseguiram, graças às suas atuações profissionais, divulgar ainda mais a imagem de Euclides da Cunha no cenário nacional. Algumas medidas tomadas por eles já foram mencionadas em outros momentos do trabalho, mas serão analisadas com mais profundidade no item a seguir.

3.2. A contribuição dos euclidianos do Rio de Janeiro para a popularização de Euclides da Cunha

Como assinalou Pierre Bourdieu, um clássico é
um best-seller de longa duração e que necessita,
para se afirmar, de intenso trabalho de
mobilização da opinião pública, por meio de
constantes reedições, elaborações de biografias
$e$ inclusão de seu estudo dos currículos

${ }^{251}$ VENANCIO FILHO, Francisco. Os Fundamentos Científicos de Os Sertões. In: VENANCIO FILHO, Alberto (org.). Francisco Venâncio Filho: Um Educador Brasileiro. Rio de Janeiro: Nova Fronteira, 1995, p. 261.

${ }^{252}$ VENTURA, Roberto. Euclides da Cunha: Esboço Biográfico. São Paulo, Cia das Letras, 2003. 


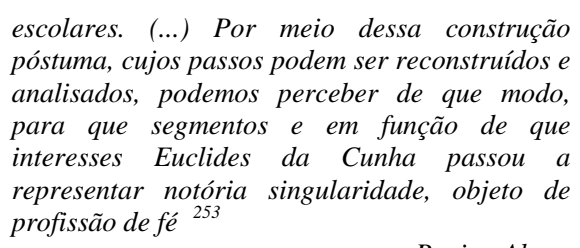
profissão de fé ${ }^{253}$

Regina Abreu

Edgard Sussekind de Mendonça, Francisco Venâncio Filho e Roquette-Pinto, como já foi mais de uma vez mencionado neste trabalho, eram os principais euclidianos, aqueles que tiveram uma atuação mais incisiva e constante no grêmio ao longo de todas as décadas. O crescimento em importância do Grêmio Euclides da Cunha do Rio de Janeiro nas décadas de 30 e 40 é correspondente ao próprio crescimento profissional de seus principais articuladores. Nas décadas citadas, estes euclidianos ocupavam importantes posições em seus respectivos campos profissionais, e possuíam uma rede de relações que lhes permitiu não tanto popularizar o Grêmio carioca, mas popularizar a obra de Euclides da Cunha, através de uma série de medidas que serão descritas e analisadas nesta seção.

A análise do Arquivo Euclides da Cunha da ABL em sua seção sobre o Grêmio do Rio de Janeiro, demonstra uma intensa atividade de Edgard Sussekind de Mendonça no âmbito do Grêmio Euclides da Cunha. Como presidente da instituição, era Sussekind de Mendonça que organizava os cursos, exposições, coletâneas e publicações sobre Euclides da Cunha, sempre auxiliado por Venâncio Filho, seu grande amigo.

No documento abaixo, de 1944, Edgard Sussekind de Mendonça, em papel timbrado onde se lê 'Secretário da Academia Carioca de Letras', escreveu informando ao professor Raja Gabaglia, diretor do Colégio Pedro II, a data de sua aula no curso que seria realizado sobre o escritor $^{254}$ :

\section{Atenciosos cumprimentos}

Em nome da comissão executiva do curso Euclides da Cunha muito me agrada comunicar-vos que as palestras do mesmo terão início a 25 do corrente e que na conformidade da seriação estabelecida a vossa palestra, sobre a geografia na obra de Euclides, será a 15 de junho vindouro.

\footnotetext{
${ }^{253}$ ABREU, Regina. O enigma de Os Sertões. Rio de Janeiro, Rocco, 1988, p. 276-277.

${ }^{254}$ Arquivo Euclides da Cunha. Série 7 Código de referência: BR ABL AA EC gec. In: Academia Brasileira de Letras.
} 
O curso será dado na Associação Brasileira de Educação (Av. Rio Branco, 91), às 17 horas exatas das quintas-feiras, e delas serão entregues cópias, ao mesmo tempo, à comissão executiva, para a imediata publicação do curso.

As instituições organizadoras do curso muito confiam no vosso patriotismo e no vosso maior empenho pela glória de Euclides, como vos agradece a solicitude com que atendeste ao convite para a realização da palestra a vosso cargo.

Em outra correspondência, dessa vez endereçada ao editor da Companhia Editora Nacional e com data de 1948, Edgard Sussekind de Mendonça sugeriu ao seu destinatário a publicação de outra obra de Euclides na conhecida Coleção Brasiliana. Criada na década de 30 e destinada a publicar a obra dos mais consagrados escritores da nação, a publicação de Euclides na Coleção Brasiliana foi, certamente, uma das formas de consolidar o nome de Euclides da Cunha entre os chamados clássicos nacionais. Mais uma vez, os euclidianos contribuíram decisivamente para isso, como pode ser notado na correspondência abaixo ${ }^{255}$ :

Amigo Octales Marcondes,

Um abraço. Já faz muito tempo que ouvi você dizer ao nosso saudoso Venâncio que, por esquecimento dos admiradores de Euclides da Cunha, a Companhia Editora Nacional deixara de editar o 'Diário de Canudos', tendo aproveitado a boa oportunidade os editores da José Olímpio. Ora, estando eu organizando para o Instituto Nacional do Livro, do ministério da educação, a edição oficial de 5.000 exemplares das obras completas de Euclides da Cunha, tenho em mãos material para um livro de Euclides, de cerca de 300 páginas, formato 'Poemas e Canções'. Esse material foi pelo Venâncio e por mim mesmo copiado de jornais antigos, e destina-se, nas obras completas que só sairão no ano de 1950 ao volume IX sob o título Fragmentos e relíquias, já tendo Afrânio Peixoto escrito o prefácio, que está comigo. Pensei, (sem remuneração qualquer em meu favor, pois considero o trabalho compromisso com a memória euclidiana) que você poderia interessar-se por essa publicação, a qual poderia, para maior atração do público, levar outro título, como por exemplo 'Páginas dispersas'. Tratando-se de um livro novo de autor tão famoso como é Euclides, creio que há grandes expectativas de lucro, tanto mais quanto o governo, para a edição acima referida que estou organizando para o Ministério da Educação, terá de adquirir dos editores do referido livro o direito a 5.000 exemplares para a edição especial das obras completas. (...)

Nós do Grêmio, tanto do Rio como de São José do Rio Pardo, veríamos com grande satisfação esse novo livro de Euclides incorporado à coleção brasiliana e eu, em especial, muito gostaria de abrir mão de qualquer remuneração pelo trabalho de organização, cópia e bibliografia da obra, em favor de uma empresa de quem tenho recebido tantas provas de amizade.

Um abraço no Fernando Azevedo

\footnotetext{
${ }^{255}$ Idem Ibidem.
} 
A correspondência acima, além de revelar a participação dos euclidianos na organização de uma coletânea que seria lançada pelo Instituto Nacional do Livro, do Ministério da Educação, sobre Euclides da Cunha, demonstra também a relação de proximidade entre Sussekind de Mendonça e Octalles Marcondes.

Octalles Marcondes era considerado, de acordo com Heloísa Pontes, um dos maiores editores nacionais, juntamente com Monteiro Lobato, Martins e José Olímpio. Em trecho do oitavo capítulo de "O Enigma de Os Sertões”, Regina Abreu comenta a questão. O primeiro trecho destacado faz menção ao surgimento de coleções como a Brasiliana, e a Documentos Brasileiros. Nos trechos seguintes, a autora destaca o papel das coleções e de seus editores ${ }^{256}$ :

Surgiam, pela primeira vez no país, coleções voltadas para a produção $e$ difusão de autores representativos do período, e a reedição de autores especialmente nacionais. As coleções brasilianas constituíram verdadeiros panteões de valores nacionais. Muitos dos livros editados transformaram-se em 'monumentos nacionais.

Os editores mais importantes que o Brasil conheceu dos anos 20 aos anos 50 foram Monteiro Lobato, Octalles Marcondes Ferreira, José Olímpio e José de Barros Martins.

A criação e ampla difusão da 'Coleção Brasiliana', aliada a outras iniciativas, como o empreendimento do jornal A Manhã, destacando no suplemento literário, 'Autores e Livros', a figura de Euclides da Cunha no panorama da produção intelectual do país (1942) e também a realização do filme didático sobre o autor pelo Instituto Nacional do Cinema Educativo (1944) representam a definitiva fixação de Os Sertões como o grande clássico nacional e Euclides da Cunha como um dos maiores heróisescritores da nação brasileira.

Além dessas medidas tomadas por Edgard Sussekind de Mendonça, as conferências sobre Euclides continuavam a acontecer, mas foram transferidas para a Academia Carioca de Letras, da qual, como já vimos, Sussekind de Mendonça era membro ${ }^{257}$. A partir da análise dos documentos e da bibliografia consultada, foi possível perceber que, enquanto Sussekind era o encarregado da administração do Grêmio- era ele que organizava as palestras, enviava as

\footnotetext{
${ }^{256}$ APUD ABREU, Regina. O enigma de Os Sertões. Rio de Janeiro, Rocco, 1988.p 328.

${ }^{257}$ Arquivo Euclides da Cunha. Série 7 Código de referência: BR ABL AA EC gec. In: Academia Brasileira de Letras.
} 
cartas aos agremiados, palestrantes e simpatizantes e correspondia-se com os colegas de São Paulo- Roquette-Pinto e Venâncio Filho participavam da parte literária, escrevendo artigos, livros e organizando novas edições dos livros de Euclides. Além disso, os três contribuíram ajudando a incluir Euclides em importantes coleções literárias nacionais, como literatura obrigatória nas escolas, entre outras medidas. O trabalho dos três amigos, em conjunto, foi fundamental para popularizar ainda mais Euclides da Cunha e sua obra.

A dedicação de Roquette-Pinto ao Grêmio já foi bastante mencionada neste trabalho. Essa dedicação foi reconhecida por Regina Abreu, que afirmou ${ }^{258}$ :

Roquette-Pinto é um capítulo à parte no euclidianismo. Abraçando a causa euclidiana, além de organizar a 'sala Euclides da Cunha' no Museu Nacional, ele proferiu palestras, redigiu artigos e contribuiu para aumentar o prestígio do escritor.

Sobre a importância da criação da Sala Euclides da Cunha, no Museu Nacional, Regina Abreu escreveu:

Outro passo para o crescimento do movimento euclidiano foi a criação da sala euclidiana, no Museu Nacional, ao lado da Sala Humboldt. A identidade entre os dois escritores era reforçada pelo pesquisador Edgard Roquette-Pinto. ${ }^{259}$

Ainda sobre esse assunto:

A iniciativa de Roquette-Pinto revelava dois aspectos importantes: primeiramente, Euclides era entronizado no panteão do naturalismo, ao lado de Humboldt. Em 1917, o naturalismo dominava ainda no campo científico, e o Museu Nacional era uma instituição prestigiada. A sala Euclides da Cunha teve importante significado de glorificação científica de Euclides $^{260}$

Outra iniciativa importante de Roquette-Pinto estava relacionada a outra de suas paixões: o cinema. Pioneiro nos - hoje - chamados meios de comunicação audiovisuais, como o rádio e o cinema, Roquette-Pinto foi o autor da proposta de criação do Instituto Nacional de Cinema Educativo, dirigido por Humberto Mauro e sediado no Museu Nacional. Esse instituto,

\footnotetext{
${ }^{258}$ Idem Ibidem

259 ABREU, Regina. O enigma de Os Sertões. Rio de Janeiro: Rocco, 1988, p.306.

${ }^{260}$ Idem. Ibidem, p.308.
} 
encarregado de divulgar a um público mais amplo, não apenas aos alfabetizados, a cultura nacional, tinha em Euclides da Cunha, de acordo com Regina Abreu, “O número um do projeto destinado a difundir a história da literatura e dos escritores no Brasil.” ${ }^{261}$. O Ince, na época, produziu dois documentários com esse intuito: um sobre Euclides e outro sobre "Os Sertões”. Com isso, o intelectual contribuía mais ativamente para a construção do mito euclidiano. Além de Roquette-Pinto, autor da proposta de criação do Instituto, Venâncio Fillho também participou da instituição, tendo sido inclusive a voz que narrava os feitos de Euclides no filme dedicado a ele. Regina Abreu, que também identifica o Ince como uma das formas pelas quais os euclidianos divulgaram, popularizaram e ajudaram a incluir Euclides da Cunha entre os maiores escritores da nação, afirma que ${ }^{262}$ :

Os primeiros contemplados com curtas-metragens do Ince foram Machado de Assis (1939), Euclides da Cunha (1944), Vicente de Carvalho (1945), Martins Pena (1947), Castro Alves (1948) e Rui Barbosa (1949). Entre os responsáveis pela implantação do projeto de filmes sobre escritores encontravam-se alguns euclidianos, como Francisco Venâncio Filho $e$ Roquette-Pinto, além do primeiro conferencista da 'Semana Euclidiana', o historiador Pedro Calmon (que proferiu a conferência de 1936). Os outros membros do grupo eram Vila-Lobos, Portinari e Santa Rosa.

Segundo Ana Cristina Cesar, tratava-se de 'um cinema pedagógico e dirigido. Ligado a uma preocupação oficial com a modernização da educação escolar; e a um ministro da Educação que atraía e protegia artistas e intelectuais, integrando-os a um esquema de amparo oficial, no interior do contraditório regime estadonovista'. Até a criação do Ince, em 1936, o cinema educativo ainda não tinha no Brasil organização com essas finalidades e recursos próprios. O ministro Gustavo Capanema levou em 1936 ao presidente Getúlio Vargas uma proposta elaborada por RoquettePinto para a criação do Ince, ' a título de ensaio e em caráter de comissão'. Em 1937, o Ince passou a existir oficialmente.

O objetivo era fazer com que o livro saísse da estante em forma de livro e se abrisse às multidões 'cheio de luz, som e claridade'. Nesse contexto, a apresentação da obra era acompanhada da narrativa biográfica do autor com 'função edificante e exemplar.

Mais adiante, a mesma autora conclui, sobre um dos principais objetivos do Ince ${ }^{263}$ :: “ $O$ principal objetivo era a projeção nas escolas. Enfatizava-se o didatismo e a exaltação patriótica. Fazia-se dupla apologia, do vulto histórico e do moderno cinema educativo". (grifos meus)

\footnotetext{
${ }^{261}$ Idem. Ibidem, p.322.

262 Idem Ibidem, p.324.

263 Idem Ibidem, p.325
} 
Além disso, as duas revistas que eram publicadas pelo Museu Nacional, denominadas Revista Nacional de Educação e Revista do Museu Nacional, que eram distribuídas para várias cidades brasileiras, continham uma infinidade de artigos sobre ou com menções ao escritor ${ }^{264}$. Assim como nos filmes, Roquette-Pinto pretendia, com as revistas do Museu Nacional, levar ao público mais amplo possível, o conhecimento científico e informações sobre a cultura nacional $^{265}$. Considerado pelos euclidianos um dos maiores, senão o maior ícone da cultura nacional, Euclides da Cunha era presença constante nas publicações. Assim, Roquette contribuía para tornar Euclides um escritor nacional, e não apenas apreciado na Capital Federal e no estado de São Paulo. Na primeira edição da Revista do Museu Nacional, datada de Agosto de 1944, seu editor esclareceu os principais objetivos da publicação ${ }^{266}$ :

Na vida já centenária da instituição há, sem dúvida, uma administração que se destaca como aquela que teve a preocupação de levar o Museu Nacional a servir a um círculo de interessados que até então nunca merecera um cuidado especial. Foi realmente, sob a direção de Roquette-Pinto que o Museu Nacional se dispôs, de uma maneira específica, a ir em auxílio de quantos se dedicavam ao ensino das ciências naturais, pondo a sua disposição todos os recursos possíveis, quer materiais, quer de orientação.

Mais adiante, o editor completou:

\begin{abstract}
A obra realizada em quase um decênio da administração Roquette-Pinto, à frente do Museu Nacional, é dessas que ficam para sempre, porque marcam um passo decisivo na compreensão que deve ter um museu moderno de suas obrigações para com a cultura popular. Não vamos relatá-la aqui. Ela vive na gratidão de centenas de humildes professoras primárias que, em todos os pontos do país, recebiam, com a ajuda eficiente, palavras de simpatia e conforto, no meio do abandono e da falta de tudo com que insistiam em realizar seu esforço ingente em prol das crianças a elas confiadas; nos milhares de alunos e professores que viram pela primeira vez franqueadas as dependências do Museu para suas visitas, aulas e cursos; no serviço beneditino de determinação de material, enviado de todos os cantos do país, para figurar depois em museus escolares, trabalho cujo vulto ultrapassava, de muito, a capacidade do pessoal encarregado, obrigando-o a grandes sacrifícios; No material de projeção, filmes e dispositivos, pela primeira vez reunido em tão larga escala à disposição de quantos dele necessitavam; na preocupação de proporcionar um aparelho de projeção acessível aos
\end{abstract}

\footnotetext{
${ }^{264}$ Revista Nacional de Educação. 1930-1940. Revista do Museu Nacional. 1944-1945.

${ }^{265}$ Idem Ibidem.

266 Revista do Museu Nacional. No 1. ano1, 1944.
} 
minguados recursos de nossas escolas, nos cursos de aperfeiçoamento para professores; nas consultas respondidas; e, acima de tudo, na própria palavra do mestre, que tinha seus melhores momentos quando se dirigia a um grupo de crianças irrequietas, ou de professores em busca de aperfeiçoamento, para lhes falar desse Brasil tão grande e tão desconhecido, infundindo-lhes, ele que o conhecia tanto, o amor à terra, ao homem e à ciência.

Nessa última frase, poder-se-ia acrescentar: infundindo-lhes o amor à terra, ao homem, à ciência e a Euclides. No último parágrafo do texto, o editor conclui: ${ }^{267}$

Destinada a servir, ela parece com aquele mesmo espírito com que Roquette-Pinto definia a principal missão do Museu Nacional, em oração comemorativa do seu centenário, em 1919: 'Nossa principal missão nessa casa, hoje, é tratar de difundir em nosso povo uma parte daquilo que ele precisa para vir a ser aquilo que merece'.

Desse modo, emprestando seu prestígio pessoal à tarefa de glorificação de Euclides, Roquette Pinto também contribuiu de maneira efetiva para transformação de Euclides da Cunha em escritor ícone da nacionalidade.

Francisco Venâncio Filho também exerceu um papel importante nessa construção, mais amplo do que apenas a militância dentro do Grêmio. Como vimos, o escritor, engenheiro de formação, assim como Euclides, optou por não exercer a profissão e por dedicar-se à educação. O professor dava aulas no colégio Pedro II e no Instituto de Educação, participou com Roquette-Pinto do Instituto Nacional do Cinema Educativo e escrevia regularmente para jornais e revistas, como as revistas do Museu Nacional, da ABL, e o Jornal do Commercio e o Boletim Ariel $^{268}$. Nesses artigos, eram constantes as menções a Euclides da Cunha, sempre retratado como o grande escritor nacional. A importância da Sala Euclides da Cunha, já mencionada e criada por Roquette-Pinto, também foi, segundo Regina Abreu, reconhecida por Venâncio Filho, como citado no trecho destacado abaixo ${ }^{269}$ :

\footnotetext{
${ }^{267}$ Idem Ibidem.

${ }^{268}$ VENÂNCIO FILHO, Alberto. Francisco Venâncio Filho: Um Educador Brasileiro. Rio de Janeiro: Nova fronteira, 1995.

${ }^{269}$ ABREU, Regina. O enigma de Os Sertões. Rio de Janeiro: Rocco, 1988, p.325.
} 
O euclidiano Francisco Venâncio Filho narrava para a Revista do Grêmio de 1918 como os euclidianos pretendiam transformar a Sala Euclides da Cunha num pequeno museu dedicado à sua memória. A sala passou a integrar a seção de etnografia sertaneja, representando para os euclidianos a 'consagração científica' do escritor.

Além de todas as funções já mencionadas, Venâncio Filho foi várias vezes presidente da Associação Brasileira de Educação, resultado de outra militância marcante em sua vida: a dos escolanovistas. De sua atuação à frente da educação surgiram as amizades de Fernando de Azevedo e Anísio Teixeira, que o consultavam com freqüência sobre as questões educacionais $^{270}$. A proximidade com essas autoridades educacionais lhe conferia o poder de interferir nos currículos escolares da época. Sobre isso, escreve, mais uma vez, Regina Abreu:

Em 1934, Fernando de Azevedo endereçou carta a um dos líderes do movimento euclidiano, Francisco Venâncio Filho, solicitando sua colaboração para a organização da Coleção Brasiliana. Venâncio Filho (1894-1946), apesar de formado em Engenharia, não exercia a profissão, dedicando-se ao magistério e aos problemas da educação. Era professor do colégio Pedro II e diversas vezes presidente da Associação Brasileira de Educação. Fernando de Azevedo solicitava que Venâncio Filho indicasse nomes para serem editados e o auxiliasse na escolha de professores para escrever livros escolares de todas as matérias que constituíam o ensino secundário. A educação ocupava o lugar central na vida do escritorprofessor. ${ }^{271}$

Pois foi exatamente nesse momento, a década de 30, que “Os Sertões” se tornaram literatura de leitura obrigatória nas escolas, Euclides foi consagrado como um dos maiores escritores nacionais e que seu mito se fortaleceu, por meio do Grêmio do Rio de Janeiro e do de S. José do Rio Pardo ${ }^{272}$. Como é possível perceber, essa construção histórica contou com o apoio decisivo dos intelectuais euclidianos do Rio de Janeiro, além daquele de São Paulo.

Ainda sobre isso, afirma Regina Abreu ${ }^{273}$ :

Se, nos primeiros anos do século, Euclides foi louvado e introduzido no rol dos escritores consagrados pela ação da trindade da 'moderna' crítica literária, José Veríssimo, Araripe Junior e Silvio Romero, foi durante o Estado Novo que a obra e o nome de Euclides passaram definitivamente a

\footnotetext{
${ }^{270}$ AZEVEDO, Fernando de. Junto a um marco do meu caminho. In: Alberto. Francisco Venâncio Filho: Um Educador Brasileiro. Rio de Janeiro: Nova fronteira, 1995.

271 ABREU, Regina. O enigma de Os Sertões. Rio de Janeiro: Rocco, 1988.

${ }^{272}$ Cfr. Idem. Ibidem.

${ }^{273}$ Idem Ibidem p. 333
} 
fazer parte do currículo escolar e universitário como referências obrigatórias para o conhecimento do Brasil.

Sobre os intelectuais estudados nesse trabalho, escreve Regina Abreu:

A transformação de Os Sertões, de livro consagrado pela crítica em monumento nacional, sua elevação à categoria de livro sagrado, clássico ou Best-Seller na longa duração foi trabalho orquestrado, e não produção do acaso. Nele, euclidianos como Roquette-Pinto e Venâncio Filho teriam atuação decisiva. ${ }^{274}$

Desse modo, seja nas suas atuações dentro do Grêmio Euclides da Cunha, seja nas suas atividades profissionais e articulações políticas, cada um dos euclidianos citados contribuiu, de maneira substancial, não só para popularizar Euclides, mas também para difundir uma certa imagem do escritor: aquela do Euclides detentor de uma postura científica, além da literária, que deveria garantir a ele um status diferenciado na história da literatura nacional. Edgard Sussekind de Mendonça, Francisco Venâncio Filho e Roquette-Pinto tinham quase que o monopólio sobre tudo o que era dito, escrito ou produzido sobre Euclides da Cunha: se não eram eles mesmos que escreviam ou produziam, editavam e publicavam sobre Euclides, eles eram sempre consultados, o que dava a esses intelectuais um poder muito grande de interferência em boa parte do que se escrevia sobre Euclides da Cunha, como reitera Regina Abreu em livro já citado ${ }^{275}$ : “ Os euclidianos foram assim, ocupando vários espaços e, gradativamente, passaram a deter o controle sobre a difusão da memória e da obra do escritor.”

O próprio arquivo de Euclides da Cunha, que continha os seus livros, anotações, correspondências, entre outros documentos estava sob a guarda de Venâncio Filho ${ }^{276}$, o que obrigava qualquer pesquisador interessado na obra do autor a entrar em contato com Venâncio, se desejasse consultar os seus arquivos. Por isso, é possível dizer que a história e a memória sobre Euclides até a década de 50 foi, basicamente, construída dentro e pelos integrantes do Grêmio Euclides da Cunha, sobretudo os do Rio de Janeiro.

\footnotetext{
${ }^{274}$ Idem. Ibidem, p. 347.

${ }^{275}$ Idem Ibidem.

${ }^{276}$ Arquivo Euclides da Cunha. Série 7 Código de referência: BR ABL AA EC gec. In: Academia Brasileira de Letras.
} 
No entanto, apesar de todo o engajamento desses intelectuais euclidianos, que resultou na divulgação e na publicação da obra de Euclides da Cunha em uma proporção muito superior àquela existente antes da sua atuação, parte considerável da intelectualidade do Rio de Janeiro parecia enxergar com desdém e desprezo a militância desse grupo. Um discurso em tom de desabafo de Carlos Sussekind de Mendonça, irmão de Edgard e também euclidiano, ocorrido no ano de 1938, demonstra bem essa situação ${ }^{277}$ :

Há mais de vinte e cinco anos que eu faço parte desse grupo, reunido, aqui, a dia certo, por protesto e adoração.

Nunca me lembro de haver faltado, uma só vez, a essa romaria, que se fez hábito sagrado de minha meninice e da minha mocidade, e tanto mais sagrado quanto ambas foram sempre vazias de outros cultos que me forçassem a essa constância de crente e de romeiro.

Minha presença, todavia, preferiu sempre à manifestação dessas palavras em voz alta, outra, mais simples, mais discreta, que se satisfazia em me fazer chegar mais cedo à beira deste túmulo e, antes que os outros se acercassem para a prece coletiva, enfeitá-lo de flores.

Fi-lo, pela primeira vez, fardado de colegial, aos dezesseis anos.

Fa-lo-ia ainda hoje, no mesmo anonimato comovido, à porta dos quarenta.

Acontece, porém, que, neste ano, o grêmio Euclides da Cunha não contava ter, aqui, a presença dos seus grandes animadores- Francisco Venâncio Filho e Edgard Sussekind de Mendonça- que deveriam ir representá-lo nas comemorações de São José do Rio Pardo.

$E$, como nunca estive ausente, e para que não o estivesse hoje, foi que aceitei essa incumbência de substituí-los, na qual insistem ambos, mesmo depois de desaparecidos os motivos do substabelecimento, de vez que não partiram.

Não é, porém, só esta, meus senhores, a razão por que aceito a outorga reiterada.

Outra existe, que deve ser dita e que não poderia ser falada por eles que são, mais do que os grandes, mais do que os principais animadores do grêmio, o grêmio mesmo.

Há vinte e cinco anos, quando se instituiu, neste recinto, o culto euclideano, não há o mínimo exagero em dizer- e eu não encontraria testemunho melhor para a confirmação dessa verdade do que esse admirável Nestor Cunha, que é hoje, com o seu primo Arnaldo, tudo o que resta da família de Euclides- há vinte e cinco anos, quando se instituiu neste recinto, o culto euclideano, não há o mínimo exagero em dizer que Euclides da Cunha era, para o Brasil, unicamente um escritor.

Grande escritor, sem dúvida, porque quem escreve "Os Sertões” não necessita, nunca, mesmo no Brasil, de quem o torne grande.

Poucos, porém, fora dos mais letrados, saberiam que ele tinha outros livros publicados.

\footnotetext{
${ }^{277}$ Idem Ibidem.
} 
E pouquíssimos, já não direi entre esses mais letrados, mas fora os seus íntimos, ousariam dizer que, tão grande como a obra, fora nele, o homem.

A lama que se misturou às suas roupas na Estrada Real de Santa Cruz não lhe sujou o corpo só.

O perjúrio, a que foi isolado, se incumbiria de fazer com que os próprios tribunais ela se lhe calasse à alma.

E, durante quatro anos, de 1909 a 1913, a não ser pelo protesto de Nestor, ao revide imediato que opôs à rabugice triunfante dos que lhe defenderam $e$ libertaram os assassinos, não teve Euclides outra voz que se erguesse em desagravo de seu nome.

Esta seria obra do Grêmio- que em vinte e cinco anos de protesto incansável $e$ adoração constante, só chamou à arena os amigos de Euclides para exumar o coração de amor perdido, que a má fé e a perfídia sepultaram, como levou à compreensão e à dignificação das massas a sua obra e o seu exemplo.

Não fora esse trabalho, impessoal e anônimo que, há um quarto de século, se empenha em reabilitar o homem, recompondo, uma a uma, as peças destroçadas de que se formara a sua esplêndida afetividade- e ampliando-a, dia a dia, pela pesquisa proba e desinteressada o seu legado intelectual deslembrado ou disperso- e hoje ainda estaria em curso, ao lado do Euclides íntimo desmoralizado, marido sem amor, cônjuge complacente e pai relapso, o historiador tendencioso e aliterado que, mesmo no seu grande livro, não fizera mais do que 'um romance mal alinhavado', sempre infiel à verdade dos fatos, a despeito das suas sucessivas edições.

Não fora esse trabalho, e o 'À Margem da História', e os 'Contrastes e Confrontos' talvez não fossem hoje mais que dois livros portugueses, desamados por estes e por nós, que mal os julgaríamos através do elogio do Dr. Sampaio Bruno.

Não fora esse trabalho, e o 'Peru X Bolívia' permaneceria tão distante do nosso público ledor quanto os sois os relatórios de reconhecimento das nascentes do Purus (...)

Não fora ele, e o Castro Alves e o seu tempo continuaria inédito entre os escombros do incêndio da imprensa nacional.

Não fora ele, e a biografia de Euclides não teria meios de vencer nem a etapa inicial da verdadeira data do seu nascimento.

Não fora ele, e as cartas, as belas cartas de Euclides, que, mais que nenhum outro de seus escritos o revelam, talvez nem se conservassem mais nos arquivos dispersos dos seus destinatários (...)

Não fora ele, sobretudo, e teriam morrido, sem depor sobre as reservas infinitas de sua sensibilidade e da sua ternura, os seus grandes amigos desaparecidos, e não é de supor que se pronunciassem nunca sobre a sua obra os que talvez melhor a tenham estudado.

\section{Entretanto...}

Entretanto, a despeito disso tudo, quando os vinte e cinco anos decorridos sobre a instituição do culto euclideano poderiam lá fora fazer de Euclides o maior dos pensadores brasileiros, e um dos exemplos mais completos do brio e do caráter nacionais, sem que em todo esse tempo tenha o grêmio deixado de ser o que foi sempre- um (...) indistinto de trabalhadores 
anônimos que somam ao desinteresse o próprio sacrifício, não poucas vezes pecuniário, para que, ao seu patrono não falte, a dia certo, a comemoração que se fizera coletiva- a despeito disso tudo, vai-se notando, agora, que essa obra do grêmio, longe de despertar o reconhecimento a que se impôs, vai parecendo a muitos uma legião de cristão novos, que só agora se apressam em fazer de cirineus quando a pesada cruz de tantos sacrifícios já se acerca de seu termo, faz-se alvo de críticas, de manhosas reservas, quando não de imbecis e irritantes (...) que a figuram, não com o zelo legítimo de quem queira cercar o grande nome apenas de discípulos à altura de seu apostolado, mas com o ciúme vesgo e o egoísmo tacanho, senão com a própria solércia criminosa dos que não queiram repartir por outras mãos um legado que é de todos.

Em seu desabafo, Carlos Sussekind de Mendonça também atribuiu ao Grêmio do Rio de Janeiro o papel de ter levado o nome de Euclides da Cunha e de sua obra a um nível de popularidade que o escritor não possuía antes do trabalho realizado por eles. Essa declaração, em conjunto com as outras citações destacadas neste item, permite que se reforce o argumento já lançado no início do terceiro capítulo: a maior popularização de Euclides da Cunha, a inclusão do escritor como um dos maiores da nação e o apoio do governo federal às medidas em homenagem a ele parecem estar mais ligados à atuação constante e incansável dos euclidianos em diversos setores do que à identidade de pensamento entre os ideólogos do Estado Novo e Euclides da Cunha, representado por seu livro de maior expressão.

Em razão do aparente pouco crédito que o Grêmio possuía entre parte da população e dos intelectuais do Rio de Janeiro, ao contrário do caso de São José do Rio Pardo, a sobrevivência do grêmio no Rio de Janeiro ficou condicionada à de seus idealizadores. À medida que eles foram envelhecendo, ou falecendo, o Grêmio foi perdendo cada vez mais influência, até deixar de existir, com a morte de Edgard Sussekind de Mendonça, Venâncio Filho e de Roquette-Pinto, os três grandes lideres da militância euclidiana. Sussekind e Roquette Pinto faleceram na década de 50. Venâncio faleceu em 1946. A amizade e colaboração existente entre os dois grêmios tornaram o Grêmio de São José do Rio Pardo o principal herdeiro de todas as relíquias e dos arquivos pertencentes aos seus colegas do Rio de Janeiro. Quando, em 1946, Francisco Venâncio Filho veio a falecer, os arquivos de Euclides da Cunha foram doados à instituição de São José do Rio Pardo, que, por meio de seus dirigentes, agradeceu inaugurando na cidade uma placa com os seguintes dizeres: ${ }^{278}$

\footnotetext{
${ }^{278}$ Idem Ibidem.
} 


\begin{abstract}
Amigos e admiradores que concorreram para a colocação, na Herma euclidiana de São José do Rio Pardo, de uma placa com os seguintes dizeres: "Do culto à memória de Euclides da Cunha, Francisco Venâncio Filho fez surgir um movimento de educação cívica sem paralelo no Brasil." Roquette Pinto. Essa placa deverá ser inaugurada no próximo dia 12 de Agosto, $5^{\circ}$ aniversário de falecimento de Francisco Venâncio, por iniciativa dos grêmios Euclides da Cunha do Rio de Janeiro e São José do Rio Pardo.

Assinaturas:

Roquette- Pinto; Anísio Teixeira; Edgard Sussekind de Mendonça; Fernando de Azevedo; Paulo Carneiro, Jorge Sussekind; Carlos Sussekind de Mendonça.
\end{abstract}

As contribuições desse grupo, dentro do Grêmio e fora dele, a partir de suas articulações profissionais, também foram de suma importância, não só para a transformação de Euclides em mito e em grande escritor nacional, mas também para a afirmação de ter sido ele um escritor positivista, já que os agremiados, que eram ligados, em maior ou menor escala, ao positivismo, preferiram ressaltar, nos inúmeros artigos, livros e conferências que produziam sobre o escritor, o que eles entendiam que fosse a sua grande qualidade, ou seja, sua postura científica. Sobre a relação do escritor com o evolucionismo de sua época, e sobre sua adesão a teorias raciais que pregavam o esmagamento das raças mais fracas pelas mais fortes, pouco foi dito. Quando se dizia alguma coisa, era sempre em um tom quase de justificativa, como se nota nesse trecho de um artigo de Roquette-Pinto sobre "Os Sertões": "Seus defeitos nascem de fatores que condicionavam a vida mental das últimas gerações.” 279

Venâncio Filho também se pronuncia de forma parecida sobre o assunto: "Convém, desde logo, lembrar, como o faz Gilberto Freire, que a ciência de Euclides só podia ser a da época, de 1900, e por conseqüencia as doutrinas que expusera as dominantes.” 280

Embora seja, de fato, importante evitar anacronismos e ressaltar que Euclides era, sim, um homem de seu tempo, essa justificativa de que a ciência de Euclides só podia ser a do seu tempo e que, portanto, sua adesão ao evolucionismo se deveu apenas a isso não parece muito convincente, até porque, embora o evolucionismo tenha sido uma corrente científica muito difundida à época de Euclides, ela não era a única, e essa não era a forma exclusiva de que

\footnotetext{
${ }^{279}$ ROQUETTE-PINTO, Edgard. “Ensaio Sobre Os Sertões”. IN Revista da Academia Brasileira de Letras. Rio de Janeiro: v.31, n. 93, set 1929, p. 79.

${ }^{280}$ VENÂNCIO FILHO, FRANCISCO. “Fundamentos Científicos de Os Sertões” In: Revista Brasileira. Rio de Janeiro: ano 5, n.9, dez 1945, p. 73.
} 
Euclides dispunha para interpretar o conflito de Canudos e o sertanejo. Essa foi uma escolha consciente do escritor, e não a única escolha possível.

Portanto, os euclidianos, que reconheciam o absurdo de interpretar a situação do sertanejo a partir de conceitos como o de inferioridade racial, mas que ao mesmo tempo admiravam profundamente o escritor e estavam envolvidos em um projeto de glorificação e até mesmo canonização do mesmo, optaram por não mencionar com freqüência os problemas da obra euclidiana, como os conceitos evolucionistas que ele utilizou fartamente. Construiu-se uma imagem de um Euclides defensor do sertanejo, defensor dos menos favorecidos, que não corresponde inteiramente ao que está escrito tanto no Diário de uma Expedição quanto em Os Sertões.

Exemplo clássico desse viés de interpretação é a frase mais conhecida de Os Sertões, “ $O$ sertanejo é antes de tudo um forte.” ${ }^{281}$ Sempre que utilizada, essa frase só aparece pela metade, o que dá a impressão de que Euclides era um defensor dos mestiços. No entanto, quando se lê a frase toda, percebe-se que não era bem assim: “O sertanejo é antes de tudo um forte. Não tem o raquitismo exaustivo dos mestiços neurastênicos do litoral”. ${ }^{282}$

A imagem construída de Euclides é muito mais generosa do que essa. O escritor aparece na crítica literária quase como pai do sertanejo. Isso se deve, também, ao trabalho desses euclidianos, que muito raramente se referiam às matrizes teóricas do escritor. Por outro lado, ao mesmo tempo em que a atuação do Grêmio favoreceu o esquecimento das correntes científicas que informavam a obra de Euclides, ela ressaltou reiteradamente a presença da ciência na obra do escritor, já que esses intelectuais acreditavam que essa era a sua grande qualidade. Essas lembranças e esquecimentos parecem ter contribuído, também, para a construção da imagem de Euclides da Cunha associada ao positivismo.

Mais uma vez, as palavras de Roquette-Pinto exemplificam muito bem a forma como a imagem de Euclides da Cunha foi construída por esses euclidianos:

Os Sertões não é um livro de literatura: é um livro de ciência e fé. E são essas as duas molas que faltam para o desencadear da nossa cultura

\footnotetext{
${ }^{281}$ CUNHA, Euclides. Obra Completa. Rio de Janeiro: Nova Aguillar, 1966, p. 105.
}

${ }^{282}$ Idem. Ibidem. 
popular: crer e aprender! (...) E quando o desânimo te infiltrar o coração, procura Euclides, ele te mostrará, com verdade e fulgor, o mundo de que és dono. $^{283}$

Ciência e fé também foram, ao que parece, os elementos que motivaram os euclidianos positivistas estudados neste trabalho a se engajar na criação e manutenção do Grêmio Euclides da Cunha e na divulgação da obra de um dos escritores que hoje figuram, sem dúvida, entre os maiores da nação.

\subsection{Euclides da Cunha ou Machado de Assis? Quem seria o maior escritor nacional?}

Como já foi dito em outros momentos, os euclidianos estudados neste trabalho tiveram participação decisiva na construção de uma imagem de Euclides associada, sempre, à ciência, que seria o diferencial do escritor em relação a outros escritores brasileiros. No livro " $A$ Glória de Euclydes da Cunha”, escreveu Venâncio Filho: “A base científica da cultura que lhe deu a escola militar salvou-o de ficar apenas na literatura, sem apoio objetivo, sem lastro de idéias, como tantas outras inteligências nossas." 284

Embora não haja nenhuma menção explícita a Machado no trecho destacado acima, há uma clara referência à suposta superioridade de Euclides da Cunha que, ao contrário de outras inteligências nossas, utilizava todo o seu conhecimento científico a serviço da literatura, recusando a escrita meramente literária, vista por Venâncio Filho como inferior. Ora, quem era considerado o maior escritor brasileiro de literatura ficcional? Machado de Assis. Embora não se possa afirmar que essa fala de Venâncio Filho tenha sido dirigida, direta ou indiretamente, ao escritor do Cosme Velho, parece evidente que a literatura de ficção e aparentemente descomprometida com uma análise sociológica e científica da realidade era menos importante para os positivistas. Por isso, eles provavelmente não concordavam com a idéia de que Machado de Assis fosse o maior escritor nacional. Outra afirmação de Francisco Venâncio Filho, presente no mesmo livro, demonstra de forma mais clara a sua opinião sobre

\footnotetext{
${ }^{283}$ ROQUETTE-PINTO, Edgard. “Euclides da Cunha naturalista”. IN Seixos rolados: Estudos brasileiros. São Paulo: Editora Nacional, 1927, p. 300.

${ }^{284}$ VENÂNCIO FILHO, FRANCISCO. “Fundamentos Científicos de Os Sertões”. IN Revista Brasileira. Rio de Janeiro: ano 5, n.9, dez 1945, p. 67.
} 
Machado de Assis ${ }^{285}$ :: “A campanha de Canudos em momento dado foi comoção nacional. Tocaria até Machado de Assis, na sua torre de marfim artística.”

A forma irônica como Machado, na opinião dos euclidianos, tratou a filosofia de Comte pode ter sido outro motivo para a pouca importância dada a Machado de Assis por parte dos euclidianos. Ivan Lins, em "História do Positivismo no Brasil”, afirma que esse é um dos motivos pelos quais Elói Pontes, também euclidiano e positivista ${ }^{286}$, autor de “ $A$ vida dramática de Euclides da Cunha” ${ }^{287}$, critica a obra machadiana. Segundo o autor ${ }^{288}$ :

Também Eloy Pontes supõe que seja Quincas Borba, publicado em 1891, uma tentativa frustrada de caricatura de Augusto Comte e do Positivismo, então em grande voga entre nós pela sua repercussão na fundação da República:

'Machado de Assis tenta uma caricatura de Augusto Comte. Tenta apenas. Desconhecendo o positivismo, seu alcance e as expressões da obra do filósofo, a caricatura sai-lhe confusa, constrangida, superficial'.

Sobre o livro de Pontes, publicado na coleção Documentos Brasileiros, afirma Regina Abreu $^{289}$ :

\begin{abstract}
A Documentos Brasileiros foi dirigida por Gilberto Freyre até o volume 18 e por Octavio Tarquínio a partir do seguinte. O primeiro volume foi Raízes do Brasil, de Sérgio Buarque de Holanda. Foi nessa coleção que veio a público, em 1938, a polêmica biografia de Euclides da Cunha, escrita por Elói Pontes, A vida dramática de Euclides da Cunha. Na mesma coleção, Elói Pontes escreveu uma biografia de Machado de Assis, intitulada A vida contraditória de Machado de Assis.
\end{abstract}

Pelos levantamentos realizados, pudemos observar que para os euclidianos o maior escritor nacional era Euclides da Cunha, como fica claro em Seixos Rolados, de Roquette-Pinto:

Com Os Sertões viu-se, pela primeira vez, no Brasil, o espírito científico concorrendo para a edificação de um grande monumento literário. (...) Os

\footnotetext{
${ }^{285}$ VENANCIO FILHO, Francisco. A Gloria de Euclydes da Cunha. Rio de Janeiro, Companhia Editora Nacional, 1940, p. 22.

${ }^{286}$ Pontes também era membro da Associação Brasileira dos Amigos de Auguste Comte.

${ }^{287}$ PONTES, Eloy. A vida dramática de Euclides da Cunha. Rio de Janeiro, José Olympio, 1938.

${ }^{288}$ LINS, Ivan. História do Positivismo no Brasil. São Paulo: Editora Nacional, 1967, p. 458.

${ }^{289}$ ABREU, Regina. O enigma de Os Sertões. Rio de Janeiro: Rocco, 1988, p 334.
} 
Sertões serão, no futuro, para o Brasil, o grande livro nacional; o que D. Quixote é para a Espanha ou Os Lusíadas para Portugal. ${ }^{290}$

Ou, ainda no mesmo texto: "Por que há de existir entre nós esse preconceito paradoxal de incompatibilidade entre a poesia e a matemática, o poeta e o engenheiro?”. ${ }^{291}$

Em outro texto, intitulado “Ensaio sobre Os Sertões”, de autoria também de Roquette Pinto, o autor ressalta de maneira enfática, mais uma vez, a postura científica de Euclides da Cunha que, a seu ver, o colocava à frente de outros tantos escritores brasileiros Os inúmeros trechos detacados abaixo fornecem uma boa idéia do que significava Euclides da Cunha para Roquette-Pinto ${ }^{292}$ :

Quando surgiu Euclides da Cunha, nossa literatura podia enumerar grandes nomes pertencentes ao sistema de que falei há pouco. Sem ir além do último século, nem falar dos contemporâneos, é suficiente recordar Gonçalves Dias e Castro Alves, Alencar e Taunay. A verdade, porém, é que ela não tinha recebido, malgrado precário disfarces românticos ou revolucionários, até então, outro alimento que não fosse o mais apurado classicismo.

Era em essência brasileira; mas denunciava, a cada passo, a influência européia, puramente literária, quase diria retórica. A ciência quase não existia para os homens de letras, ou, às vezes, existia demais...

Em geral, algumas gotas de mel grego, tragos de vinho do Latim e, principalmente, muitas flores recebidas da França. Cantava, de certo, a vida dos índios; lastimava a sorte dos negros; narrava a existência e pintava ademanes dos tipos do povo. Mas ninguém tratava de ver, pela ciência, a terra e o homem que dela era, a um tempo, senhor e escravo.

Senhor de cultura científica segura, possuindo pendor natural para a filosofia, dono de ótimas e variadas reminiscências literárias, realizou, sem querer, o grande livro nacional, longe de qualquer deliberada preocupação artística.

Para Os Sertões o artista seguiu ao lado do historiador, matizando os episódios pela emoção pessoal. E se o cronista não fosse homem habituado às ciências naturais, daquela diligência policial não brotaria nunca o maior livro do Brasil.

O sertanejo pagou com a vida o seu atraso; o litoral não pôde compreender o fenômeno social que Euclides da Cunha pôs em foco, de um modo fulgurante. Só lhe faltou, ao grande criador, encontrar na mecânica o termo que sua linda imagem sugere: a defasagem social. "Canudos" e o "Contestado"- muito diferente do caso dos Muckers do Rio Grande- foram

\footnotetext{
${ }^{290}$ ROQUETTE-PINTO, Edgard. "Ensaio Sobre Os Sertões”. In: Revista da Academia Brasileira de Letras, Rio de Janeiro: v.31, n.93, set 1929, p. 78.

${ }^{291}$ Idem. Ibidem, p. 82.

${ }^{292}$ Idem Ibidem, p. 82-83.
} 
tradução do mesmo fenômeno, em regiões extremas do país. Casos de grande significado provaram a unidade espiritual da população $e$ documentaram a defasagem histórica do interior com o litoral.

Houve tempo em que se acreditava que a verdade repelia a beleza ou, pelo menos, dela não precisava. Euclides da Cunha provou que elegância e vigor de frase, imagens rutilantes, sombras e colorido, que são do manejo corrente dos bons escritores, nada perdem quando o autor conhece bem as relações que ligam os fenômenos descritos- o que por si só caracteriza o espírito científico. Um escritor desse porte não poderia ter surgido aqui senão depois de 70 ou mesmo 89; só poderia aparecer depois da cristalização de certos elementos da nossa vida social. As belezas do grande livro, e até os seus defeitos, nasceram de fatores que condicionaram a vida mental das últimas gerações do império.

A introdução do espírito científico na literatura histórica, o colorido romântico que ele deu, talvez sem querer, a todas as suas grandes páginas sintonizando-as com o meio intelectual, a identificação do escritor com a natureza, cujos acidentes ele estava perfeitamente bem preparado para entender, são os parâmetros da grande figura.

Dessa maneira, considero que havia outros interesses envolvidos nessa exaltação da figura de Euclides. Havia também um projeto de valorização de um modelo de literatura científica que, para ser bem sucedido, precisava convencer a intelectualidade de sua superioridade em relação a outros modelos, entre eles aquele cuja figura de maior destaque era Machado de Assis. O grande livro nacional não podia ser “Dom Casmurro”. Devia ser “Os Sertões”, que continha uma espinha dorsal científica, nas palavras de Venâncio Filho ${ }^{293}$, e ainda foi o responsável pela redenção e integração do sertanejo no cenário nacional. Na opinião dos euclidianos, a ausência de uma preocupação científica informando a produção de Machado de Assis o colocaria em desvantagem se comparado a Euclides da Cunha. É verdade que os euclidianos nem sempre se referiam diretamente a Machado de Assis, mas mesmo a falta de referência a Machado contribuiria para solidificar a idéia de que apenas Euclides da Cunha foi o grande escritor nacional, o que foi visto por Álvaro Lins, crítico literário da época, como uma falha. Em texto intitulado "O culto de Euclides e o ideal nacionalista” ${ }^{294}$, escreveu o crítico:

Ocorre-me agora: estava deste modo promovida a entronização do autor de Os Sertões. Porém- ainda mais curioso- notei que o nome de Machado de Assis nem sequer apareceu citado ao lado do nome de Euclides da Cunha. Nesse capítulo dos Ensaios Brasilianos, esboça Roquette-Pinto um quadro

\footnotetext{
${ }^{293}$ Cfr. VENÂNCIO FILHO, Francisco. “Fundamentos Científicos de Os Sertões”. In: Revista Brasileira. Rio de Janeiro ano 5, n.9, dez 1945.

${ }^{294}$ LINS, Álvaro. ”O Culto de Euclides e o Ideal Nacionalista”. In: Jornal de Crítica. Rio de Janeiro: O Cruzeiro, 1963, p. 223-224.
} 
com a disposição em relevo de ambas as tendências ou correntes da literatura brasileira (...)

Pois bem: situadas modestamente em terra firme, compondo, como precursores, a auréola de Euclides da Cunha, são afinal invocadas, nessa tão significativa página roquetiana, algumas figuras mais antigas, conquanto todas do século XIX, tão-só para fundamentar historicamente a argumentação: Ei-las: Gonçalves Dias, Castro Alves, Taunay...

Exatamente: nessa ordem. Machado de Assis, porém, este não aparece em qualquer espécie de citação dos Ensaios Brasilianos. O seu grande preço em rivalidades ou disputas de tal natureza-era o silêncio. Aqui, no caso desse quadro roquetiano, a por em destaque o fenômeno das correntes literárias bem nítidas em nossa literatura, fez-se como se a outra não existisse, representada ou encarnada em seres vivos. Que, num caso desses, em estudos-tentativas de análise ou discriminação das nossas duas tendências literárias, se entre a invocar e exaltar Euclides da Cunha, como expoente de uma delas, sugerindo que a sua obra impetuosa poderá sufocar e aniquilar todo o lado oposto do rio, sem que o nome de Machado de Assis seja mencionado, sequer de passagem ou ao acaso, como o representante por excelência da outra corrente-então, que escândalo, ou que ingenuidade.

Mais adiante, o crítico complementou:

Onde, quando, como se haveria Roquette-Pinto ocupado de Machado de Assis? (...) Esquivando-me ao ridículo de proporcionar conselhos, $e$ conselho póstumo a um Roquette-Pinto, tenho ímpeto, porém, neste caso, de exclamar: - Sejamos mais humildes! $!^{295}$

Nesse mesmo texto, Álvaro Lins criticou a devoção de Roquette-Pinto a Euclides, que o impediu de enxergar falhas na obra de seu ídolo. Álvaro Lins também criticou o desejo incessante de Roquette-Pinto de tornar Euclides o grande escritor nacional:

Fez-nos, hoje, sentir o seu desejo de ver Euclides não apenas sentar-se sozinho no trono do Reino das letras, sim, também de estabelecer toda uma linha divisória entre literatura brasileira antes de Os Sertões e depois de Os Sertões. ${ }^{296}$

Ainda no mesmo artigo, Álvaro Lins identificou o tipo de literatura valorizada por Roquette e as causas da adoração de Roquette por Euclides. Segundo Lins:

Para Roquette- Pinto, a literatura interessava sobremaneira pelos seus significados científicos, psicológicos, sociológicos, ideológicos, históricos, sociais. (...) Punha em segundo plano o significado por excelência estético

\footnotetext{
${ }^{295}$ Idem Ibidem, p. 225.

${ }^{296}$ Idem Ibidem, p. 340.
} 
daquelas obras, às vezes menos vistosas, de autores com intenções resguardadas nos requintes da simbologia, sem ênfase verbal e exibição eloqüente de nacionalismo, não obstante muitas vezes trazerem também, a seu modo, uma substância brasileira e traduzirem uma realidade social. ${ }^{297}$

Para a vitória acabada do sistema sobre o movimento-Roquette-Pinto recebe Euclides da Cunha como a um São João Batista, pregador e anunciador da nova idade histórica. Ora, qual a missão trazida, o papel desempenhado, a revolução jogada em praça pública pelo gênio de Euclides? Vejamos (...) em que consistiram as esperanças mais verossímeis $e$ as inovações realmente concretizadas, vindas umas e outras no bojo de Os Sertões. (...)

Demonstrava-se, com o surgimento de Euclides da Cunha, a exprimir-se como cientista e como poeta entrelaçadamente, que a primeira novidade de Os Sertões impunha-se na apresentação do fenômeno cultural - possível já verificado em outros países, mas inédito no Brasil - de um concreto 'espírito científico' a planejar ou impulsionar a 'edificação de um grande monumento literário.' 298

Para Roquette-Pinto, a principal originalidade de Euclides da Cunha, em Os Sertões, foi mostrar a possibilidade de uma suprema construção literária sobre a base de uma lógica científica. ${ }^{299}$

E, sobre a postura de Roquette-Pinto em relação a seu ídolo, Lins escreveu: "Como avançar, porém, um pouco mais, para aceitar ou para divergir, quando nada resta, neste problema de crítica, senão o monólogo de um homem ilustre em estado de paixão ante seu ídolo?”. 300

Portanto, a crítica que Álvaro Lins fez a Roquette-Pinto não se restringiu a apontar o que para ele seria uma adoração em excesso a Euclides da Cunha, que comprometeria o seu espírito crítico em relação ao escritor. Lins também ressaltou que essa adoração e essa vontade de, a todo custo, alçar Euclides ao posto de maior escritor nacional, implicava em esquecimentos que poderiam ser chamados de silêncios eloqüentes. Para Lins, transformar Euclides no maior escritor nacional, esquecendo-se, propositalmente ou não, da figura de Machado de Assis era, no mínimo, uma atitude pedante. Daí o conselho: “(...) Sejamos mais Humildes!” 301.

Para o presente trabalho, a atitude de Roquette-Pinto não foi uma atitude pedante, mas sim política. Como vimos, o autor era médico de formação, naturalista de profissão e positivista por convicção, considerava a literatura científica superior à ficcional. Desse modo, não fazia sentido comparar Machado de Assis a Euclides da Cunha. Certamente, para ele como para

\footnotetext{
${ }^{297}$ Idem Ibidem, p. 220.

${ }^{298}$ Idem Ibidem, p. 221-222.

${ }^{299}$ Idem Ibidem, p. 222.

${ }^{300}$ Idem Ibidem, p. 223.
} 
Venâncio Filho, Euclides da Cunha era um escritor muito superior a Machado de Assis e por isso este último deveria, mesmo, perder a titularidade de principal escritor brasileiro, para que Euclides, e não Machado fosse lembrado como maior escritor nacional.

Alceu Amoroso Lima também entrou na discussão. Em ensaio denominado "Euclides $e$ Machado" 302, o crítico literário faz comparações entre os estilos dos dois escritores: “Euclides da Cunha era o sertão, Machado de Assis, o litoral. Euclides, a voz do povo, Machado, a voz da elite. Predominava num a terra e no outro o homem. Naquele o espírito científico e neste o espírito literário.” 303

No entanto, Amoroso Lima parecia discordar, também, dos euclidianos: “Machado de Assis não foi menos brasileiro que Euclides da Cunha, apenas o foi de outro modo. A seu jeito. „304

Outro grande intelectual nacional que lançou mão de comparações entre Euclides da Cunha e Machado de Assis foi Gilberto Freire. Em livro intitulado "Perfil de Euclides e Outros Perfis” ${ }^{305}$, Freire também deu destaque à formação científica e às preocupações de cunho sociológico que levaram o escritor a escrever sobre o sertanejo, ao invés de seguir o padrão franco-inglês de literatura. Sobre a época em que Euclides escreveu Os Sertões, escreveu Gilberto Freire:

Era o tempo em que o velho Machado, escondendo-se por trás de personagens sempre brancos, ioiôs sempre finos, se fazia adivinhar no humour dos seus romances - talvez o mais profundo dos que já se escreveram na língua portuguesa - quase um inglês triste desgarrado nos trópicos, embora resignado à doçura da vida suburbana de chá com torradas, partidas de gamão e modinhas ao piano, nos sobrados velhos $e$ nas chácaras cheias de escravos e de árvores do Rio de Janeiro de D.Pedro II. ${ }^{306}$

E mais adiante, complementou o escritor:

\footnotetext{
${ }^{301}$ Idem Ibidem, p. 225.

${ }^{302}$ LIMA, Alceu Amoroso. “Euclides e Machado”. In: Três ensaios sôbre Machado de Assis. Belo Horizonte: P. Bluhm, 1941, p. 178.

${ }^{303}$ Idem Ibidem, p.178.

${ }^{304}$ Idem Ibidem, p. 179.

${ }^{305}$ FREIRE, Gilberto. Perfil de Euclides e outros perfis. Rio de Janeiro: José Olympio, 1944.

${ }^{306}$ Idem Ibidem, p.18.
} 
Ao helenismo do tempo, ao academicismo reniano, à imitação do humour inglês- que em Machado foi assimilação genial- Euclides não escaparia de todo. Há nele uma declaração expressiva: que se sentia ao mesmo tempo tapuia, celta e grego. Mas já era muito, em plena época de Coelho Neto e B. Lopes, admitir um escritor vitorioso do Rio de Janeiro que fosse um terço tapuio, e não completamente heleno. ${ }^{307}$

Sobre o lugar da ciência na obra euclidiana, acrescentou Gilberto Freire:

Nem o poeta, nem o profeta, nem o artista me parece que turvam n'Os Sertões ou noutro qualquer dos ensaios de Euclides da Cunha- as qualidades essenciais de escritor fortalecido pelo traquejo científico, enriquecido pela cultura sociológica, aguçado pela especialização geográfica.

Desse modo, alguns dos nomes importantes da crítica literária e intelectuais brasileiros dos anos 30 e 40 recorriam, constantemente, a comparações entre Machado de Assis e Euclides da Cunha. Tantas e repetidas comparações, feitas por diferentes escritores, permitem que seja levantada a hipótese de que havia uma discussão nos meios acadêmicos sobre quem seria o maior escritor nacional, ou o mais brasileiro dos escritores nacionais: Machado de Assis ou Euclides da Cunha? A essa possível pergunta, cada crítico parecia responder de forma diferente, e de acordo com sua concepção ideológica e de literatura nacional. Há, em Gilberto Freire, mais afirmações em que aparecem comparações entre os dois escritores:

De Euclides da Cunha pode-se afirmar hoje que é um dos escritores brasileiros que maior influência vem exercendo sobre a gente de seu país e maior atenção da parte de estrangeiros vem atraindo para a cultura, em geral, e para as letras, em particular, de um ainda obscuro Brasil. Dois seriam hoje seus rivais, mais nessa espécie de influência do que nesse poder de sedução sobre estrangeiros: José de Alencar e Machado de Assis. Ambos menos carismáticos que o autor de Os Sertões. ${ }^{309}$

Portanto, para Gilberto Freire, Euclides da Cunha parecia mais carismático aos olhos de possíveis leitores estrangeiros do que Machado de Assis ou José de Alencar. Possivelmente essa era a sua opinião, e não a de estrangeiros, já que o escritor, apesar de reconhecer o talento inegável de Machado de Assis, parecia achar a sua literatura de futilidades inferior àquela de cunho científico e sociológico de Euclides da Cunha. Para Freire, Euclides utilizava a arte para fazer ciência e, mais do que isso, para fazer uma grave denúncia: a de que os sertanejos

\footnotetext{
${ }^{307}$ Idem Ibidem, p. 19.

${ }^{308}$ Idem Ibidem, p. 35.

${ }^{309}$ Idem Ibidem, p. 51
} 
não estavam sendo incluídos como cidadãos nesse Brasil republicano, que se pretendia progressista e modernizador. Eles estavam sendo deixados à margem desse processo, ou, para utilizar os conceitos evolucionistas nos quais se baseava Euclides, estavam sendo deixados em um estágio evolutivo inferior àquele do Brasil litorâneo.

Dessa maneira, a literatura de cunho analítico, a que pretendia fazer uma análise sociológica do Brasil, era entendida como mais brasileira do que a literatura machadiana por alguns críticos daquele período. Ao que parece, não havia nesses escritores a idéia contemporânea de que a literatura de Machado de Assis, escondida sob o que viam como uma aparência de futilidade, constituiu-se em uma importante maneira de analisar e problematizar a sociedade urbana carioca do século $\mathrm{XIX}^{310}$. O próprio Álvaro Lins, que escreveu na década de 60, apontou no seu trabalho a existência de uma nova interpretação sobre a obra machadiana ${ }^{311}$ :

Diferentes sim, mas ambos brasileiros. Já muito longe vai o lugar-comum de que Machado de Assis é um escritor pouco ou nada brasileiro, fruto feliz, porém artificial, de influências e correntes estrangeiras num americano (...). Entretanto, já ninguém ignora que se impôs, modernamente, uma diversa e correta interpretação sociológica da obra de Machado de Assis.

No entanto, aos olhos de Gilberto Freire e de outros euclidianos, como Roquette-Pinto, a literatura euclidiana tinha um caráter mais engajado, de comprometimento com a temática social, do que a literatura de Machado de Assis. Por outro lado, para Gilberto Freire, e ao contrário do que diziam os euclidianos Roquette-Pinto e Venâncio Filho, não era o caráter científico da obra de Euclides que a fazia especial: para Freire, além de seu caráter analítico e engajado, a excepcionalidade da obra euclidiana estava na conjugação de arte e ciência, com predomínio da arte, e não da ciência. Nas palavras do próprio escritor: “A verdade é que é livro complexo: notável como literatura e notável como ciência. Ciência ecológica e ciência antropológica e até sociológica. Mas, sobretudo, obra de literatura. Obra de revelação.” 312

\footnotetext{
${ }^{310}$ CHALHOUB, Sidney. Machado de Assis, historiador. São Paulo: Companhia das Letras, 2003.

${ }^{311}$ LINS, Álvaro. ”O Culto de Euclides e o Ideal Nacionalista”. IN Jornal de Crítica. Rio de Janeiro: O Cruzeiro, 1963, p. 227.

${ }^{312}$ FREIRE, Gilberto. Perfil de Euclides e outros perfis. Rio de Janeiro: José Olympio, 1944, p. 55.
} 
E, mais adiante: “Diz-se da ciência que é analítica, teórica e impessoal, enquanto a arte é sintética, prática e impessoal, além de orgânica. Na obra de Euclides da Cunha predominaram as virtudes artísticas sobre as científicas.” 313

Se as afirmações de Gilberto Freire forem comparadas com as de Roquette-Pinto e Venâncio Filho, notar-se-á que a importância atribuída ao conhecimento científico em Euclides da Cunha variava de acordo com as intenções, ou com as próprias conviç̧ões de cada analista. Enquanto, os segundos eram positivistas e engenheiros ou médicos de formação, o primeiro não era positivista e era sociólogo. Esse pode ser um dos motivos da discordância dos escritores em relação ao grau de importância atribuído à ciência na obra de Euclides da Cunha. No entanto, o que interessa ao presente trabalho não é entrar nessa discussão, e sim apontar como a discussão e as comparações entre os dois escritores, Machado de Assis e Euclides da Cunha eram frequentes e possibilitam a suposição de que, de fato, uma discussão havia se instalado nos meios literários. Sendo assim, e embora essa questão tenha dividido opiniões, é possível afirmar que os euclidianos obtiveram sucesso em sua insistência de incluir Euclides como um dos maiores escritores nacionais. Acredito que, para isso, foram fundamentais os trabalhos de divulgação da vida e obra euclidianas realizados por Edgard Sussekind de Mendonça, Roquette-Pinto e Venâncio Filho, embora eles não tenham sido os únicos engajados nesse projeto. Como já foi explicitado, havia inúmeros euclidianos que, por outros motivos, engajaram-se na luta pela mitificação de Euclides e pela sua inclusão no panteão dos maiores escritores nacionais.

Na perspectiva dos euclidianos, “Os sertões” tinha ainda outra vantagem, além de sua incontestável superioridade sob o ponto de vista científico: também para eles, assim como para Freire, este era um livro que se preocupou em diagnosticar os reais problemas da nação, e não com frivolidades e historinhas à francesa, como faziam os escritores de literatura urbana. Para eles Euclides da Cunha dedicou-se a fazer um estudo científico e sociológico do verdadeiro Brasil, aquele que era depositário de nossas tradições e que ainda não havia corrompido seus costumes com a invasão da cultura estrangeira ${ }^{314}$. Nesse sentido, mais uma vez, aparece o argumento de que Euclides da Cunha era o maior escritor nacional por ter sido o mais brasileiro deles, aquele que se preocupou com os reais problemas da nação, ao contrário de escritores como Machado de Assis.

\footnotetext{
${ }^{313}$ Idem. Ibidem, p. 66.
} 
Essa rivalidade criada pelos críticos literários entre os dois escritores também é mencionada por Regina Abreu. Ao comentar a inclusão de Euclides da Cunha entre os autores comentados do suplemento literário do jornal A Manhã, intitulado Autores e Livros, ocorrido na década de 30 , a estudiosa afirma que ${ }^{315}$ :

No panteão dos grandes escritores nacionais da série 'Autores e Livros' estava o poeta euclidiano Vicente de Carvalho, o crítico literário Araripe Junior, o escritor Machado de Assis, o poeta simbolista Cruz e Souza, o político e escritor Rui Barbosa, entre outros. O suplemento traçava o perfil de Euclides da Cunha por oposição a Machado de Assis. Enquanto Machado corporificava o 'literato, cidadão litorâneo', cuja obra se caracterizava pelo 'cosmopolitismo dissolvente', Euclides representava 'o sociólogo que adentrou o sertão'. Seu pensamento era a expressão da 'força original da terra'. Reiterava-se o antigo confronto entre os que viam o Brasil do ponto de vista do litoral e da cidade e aqueles que o viam do ponto de vista do sertão e do interior. A literatura de Machado passaria a representar a parte falsa do Brasil, porque voltada para a cultura importada; a de Euclides seria a expressão da nacionalidade autêntica. A valorização do mundo rural era concomitante à desqualificação do universo urbano. Fazer como Machado, que escolheu temas urbanos, era das as costas ao 'Brasil real'.

Desse modo, também no jornal A Manhã a obra de Euclides da Cunha era analisada por oposição à de Machado de Assis, sugerindo que, de fato, havia uma divisão entre a intelectualidade daquele período: alguns consideravam a literatura de Machado de Assis superior à de Euclides da Cunha, enquanto outros davam preferência a Euclides. Essa polêmica parece ter se estendido pelas décadas subseqüentes, uma vez que o estudo de Álvaro Lins, o mais recente de todos, data da década de 60.

Com isso, criou-se uma incompatibilidade póstuma entre os dois escritores que não existia na época em que os dois eram vivos. Euclides nutria grande admiração por Machado de Assis e chegou a escrever ao pai para contar, com alegria, que havia recebido votos do citado escritor e do Barão do Rio Branco para entrar na Academia Brasileira de Letras ${ }^{316}$. Quando da morte de Machado, Euclides escreveu longo artigo exaltando o escritor, que para ele havia sido um

\footnotetext{
${ }^{314}$ Revista do Grêmio Euclides da Cunha. 1919-1939.

${ }^{315}$ ABREU, Regina. O enigma de Os Sertões. Rio de Janeiro: Rocco, 1988.

${ }^{316}$ Cfr. CUNHA, Euclides. Obra Completa. Rio de Janeiro: Nova Aguillar, 1966.
} 
exemplo de genialidade entre os escritores brasileiros ${ }^{317}$. Portanto, não havia nenhuma rixa entre os dois escritores enquanto vivos. Essa foi outra construção da crítica de ambos.

Não se pretende afirmar aqui que foram apenas os euclidianos que possibilitaram a ascensão de Euclides à categoria de um dos maiores escritores nacionais e que, portanto, foram eles os únicos responsáveis pela discussão entre intelectuais da época acerca de quem seria o maior ou o mais brasileiro dos escritores nacionais. Certamente outros fatores estão envolvidos nessa construção, como as críticas favoráveis ao livro recebidas já na época do lançamento de Os Sertões, a morte trágica do escritor, as similaridades entre o projeto nacionalista do Estado Novo e as idéias de Euclides da Cunha, além do próprio talento de Euclides, que é inegável. Este é outro aspecto importante que deve ser assinalado. Não é intenção deste trabalho afirmar que, já que a afirmação de que Euclides da Cunha é um dos maiores escritores nacionais é, em parte, resultado de uma longa militância euclidiana, ele não merece ser considerado como tal. Euclides da Cunha foi, de fato, um escritor de muito talento, e não se pretende discutir a validade ou não de Euclides da Cunha ser considerado um dos maiores escritores da nação.

O que se deseja aqui é lançar mais uma hipótese, e apontar mais um grupo que foi importante na construção dessa memória euclidiana e, mais do que isso, na transformação do escritor, de grande sucesso literário, em ícone nacional e grande símbolo da brasilidade: o grupo de fundadores e dirigentes do Grêmio Euclides da Cunha. Para isso, como foi possível perceber nesse item, os euclidianos não apenas contribuíram para aumentar a publicação de e sobre Euclides, mas também insistiram na idéia de que Euclides era o maior escritor nacional e que, portanto, deveria ser reconhecido como tal, causando discussão e divergência nos meios acadêmicos e na crítica literária do período.

É importante, também, dedicar um espaço deste trabalho à análise do conceito de memória, constantemente utilizado pelos euclidianos, e à obsessão dos mesmos pela comemoração e rememoração freqüente da figura de Euclides da Cunha.

\footnotetext{
${ }^{317}$ Cfr. Idem Ibidem.
} 


\subsection{A obsessão comemorativa e a luta contra o esquecimento: características dos grêmios Euclides da Cunha}

Em todas as partes destacadas dos discursos proferidos por euclidianos em homenagem a Euclides da Cunha, desde a criação do Grêmio, prevalece a intenção de não deixar a memória do escritor cair em esquecimento e de assim imortalizá-lo pela sua obra, comemorando, a dias certos, a vida, os feitos e a obra daquele que, para esses euclidianos, havia sido o maior escritor nacional. A importância e a recorrência do conceito de memória nos escritos euclidianos exige que se faça uma reflexão mais aprofundada sobre o tema, e suas relações com a história. Jeanne Marie Gagnebin, em livro intitulado "Lembrar escrever esquecer", analisa o conceito de memória e a preocupação de historiadores que, desde a antiguidade, utilizavam a narrativa histórica como uma forma de impedir que certos feitos heróicos e seus respectivos personagens caíssem em esquecimento. Essa luta contra a morte definitiva que caracterizaria o esquecimento acerca de determinados acontecimentos é um dos objetivos de Heródoto, como afirma a estudiosa:

Quando, no início de História, Heródoto declarou que ele apresentaria 'os resultados de sua pesquisa, a fim de que o tempo não suprimisse os trabalhos dos homens e que as grandes proezas realizadas seja pelos gregos, seja pelos bárbaros, não caíssem em esquecimento', ele toma para si a tarefa sagrada do poeta épico, transformando-o ao mesmo tempo pela busca das causas verdadeiras: lutar contra o esquecimento, mantendo a lembrança cintilante da glória (Kleos) dos heróis, isto é, fundamentalmente, lutar contra a morte e a ausência pela palavra viva e rememorativa. ${ }^{318}$

Ainda de acordo com a autora:

Como a estela funerária, erguida em memória do morto, o canto poético luta igualmente para manter viva a memória dos heróis. Túmulo e palavra se revezam nesse trabalho de memória que, justamente por se fundar na luta contra o esquecimento, é também o reconhecimento implícito da força deste último: o reconhecimento do poder da morte. ${ }^{319}$

Dessa maneira, o esforço desse conjunto de intelectuais, que organizaram encontros, cursos, livros, coleções, romarias ao túmulo de Euclides, entre outras ações de caráter comemorativo, pode ser lido, assim como no caso de Homero, como uma tentativa de preservar a memória e

\footnotetext{
${ }^{318}$ GAGNEBIN, Jeanne Marie. Lembrar escrever esquecer. São Paulo: Editora 34, 2006, p. 45.
} 
os 'feitos heróicos' de Euclides da Cunha do esquecimento. No entanto, ao lutar contra o esquecimento de Euclides e pela preservação de sua memória, os euclidianos não apenas a preservaram, mas também construíram, criaram uma imagem sobre Euclides da Cunha que atendia aos seus interesses, ou seja, a do Euclides da Cunha, homem de literatura e ciência, e por isso credenciado a ocupar o posto de maior escritor nacional ${ }^{320}$. O trecho abaixo, de autoria de Roquette-Pinto, evidencia mais uma vez a valorização dos euclidianos aos aspectos científicos da obra de Euclides da Cunha ${ }^{321}$ :

O que desejo afirmar é que Euclides da Cunha mostrou como se pode tomar base lógica científica, para supremas construções literárias. O que há de notável, nos Sertões, desse ponto de vista, não é a minúcia técnica, às vezes até inaceitável, é o espírito científico que trava todo o edifício.

Valorizar Euclides da Cunha e o tipo de literatura produzida por ele pode ter sido, também, uma forma de defender que a ciência tivesse mais espaço em campos onde ela tradicionalmente não aparecia com muita freqüência, como o da literatura. Nas palavras de Venâncio Filho, que afirmava ter sido "prejuízo da nossa cultura esse predomínio literário” ${ }^{322}$, também é possível perceber a preferência dada por esses intelectuais à literatura produzida por homens de ciência.

Pleitear o posto de maior escritor nacional a Euclides da Cunha também pode ter sido uma maneira, consciente ou não, de atribuir à literatura que utiliza conceitos e teorias científicas e que, mais do que 'apenas' contar uma história, produz um estudo documental sobre um determinado assunto, além de uma denúncia social sobre os graves problemas ocorridos no interior do país, um status diferenciado em relação a outros tipos de literatura, como a literatura de ficção. Nesse sentido, o resgate e a preservação de uma determinada memória têm objetivos claros e ligados à transformação do presente, como afirma Gagnebin:

Proporia, então, uma distinção entre a atividade de comemoração, que desliza perigosamente para o religioso, ou, então, para as celebrações de Estado, com paradas e bandeiras, e um outro conceito, o de rememoração, assim traduzindo aquilo que Benjamin chama de Eingedenken, em oposição à Erinnerung de Hegel e às várias formas de apologia. Tal rememoração

\footnotetext{
${ }^{319}$ Idem Ibidem.

${ }^{320}$ ROQUETTE-PINTO, Edgard. Ensaio Sobre Os Sertões. Revista da Academia Brasileira de Letras, Rio de Janeiro, v.31, n.93, set 1929, p. 82.

${ }^{321}$ Idem Ibidem.

${ }^{322}$ VENÂNCIO FILHO, Francisco. Fundamentos Científicos de Os Sertões. IN Revista Brasileira. Rio de Janeiro: ano 5, n.9, dez. 1945, p. 70.
} 
implica uma certa ascese da atividade historiadora que, em vez de repetir aquilo de que se lembra, abre-se aos brancos, aos buracos, ao esquecido e ao recalcado, para dizer, com hesitações, solavancos, incompletude, aquilo que ainda não teve direito nem à lembrança nem às palavras. A rememoração também significa uma atenção precisa ao presente, em particular a estas estranhas ressurgências do passado no presente, pois não se trata somente de não esquecer o passado, Ma também de agir sobre o presente. A fidelidade ao passado, não sendo um fim em si, visa à transformação do presente. ${ }^{323}$

Nessa perspectiva, as atividades do Grêmio Euclides da Cunha e de seus membros seriam de comemoração, mas também de rememoração, além da produção de uma memória específica sobre o autor de Os Sertões. De acordo com Regina Abreu, o caso do culto euclidiano, iniciado no Rio de Janeiro e continuado em São José do Rio Pardo, é um caso típico de uma invenção de tradição, em que a cidade de São José do Rio Pardo figura como o principal lugar de memória para os euclidianos. Nas palavras da autora:

O culto a Euclides da Cunha em São José do Rio Pardo constitui exemplo notável de invenção de uma tradição no Brasil, com ritual que se repete anualmente desde 1912. Os adeptos do culto situam como um marco de origem o dia 15 de agosto de 1912, quando a morte trágica de Euclides completava três anos. ${ }^{324}$

Para fundamentar a relação entre o caso euclidiano e uma invenção de tradição, a autora cita trechos do estudo de Eric Hobsbawm, intitulado “A Invenção das Tradições” ${ }^{325}$ :

As tradições inventadas podem estar significando 'reações a situações novas que ou assumem a forma de referência a situações anteriores, ou estabelecem seu próprio passado através da repetição quase obrigatória. As tradições inventadas implicam automaticamente uma continuidade com relação ao passado. No processo de invenção das tradições, a legitimidade é alcançada por meio de repetições rituais de histórias sobre origens.

Em outras palavras, a invenção de uma tradição (e também a construção de um lugar de memória) implica o estabelecimento de uma origem e de uma história. A permanência de uma tradição está também condicionada à sua permanente atualização. Para essa dinâmica, o simples ato de narrar a história de fundação constitui um dos pilares de sustentação. ${ }^{326}$

Desse modo, medidas como a instituição de um feriado em homenagem ao escritor, o tombamento da cabana em que ele escreveu “Os Sertões”, a criação de eventos

\footnotetext{
${ }^{323}$ GAGNEBIN, Jeanne Marie. Lembrar escrever esquecer. São Paulo: Editora 34, 2006, p.55.

${ }^{324}$ ABREU, Regina. O enigma de Os Sertões. Rio de Janeiro, Rocco, 1988, p.312.

${ }^{325}$ HOBSBAWM, Eric; RANGER, Terence O. A Invenção das tradições. Rio de Janeiro: Paz e Terra, 1984.

${ }^{326}$ APUD ABREU, Regina. O enigma de Os Sertões. Rio de Janeiro, Rocco, 1988, p 311 e 312.
} 
comemorativos anuais e a repetição constante de que a cidade de São José do Rio Pardo foi o berço de “Os Sertões” foram fundamentais na invenção da tradição rio-pardense. Todas essas atividades já foram relatadas com maiores detalhes no item do início do capítulo, sobre a cidade e o grêmio do interior de São Paulo.

A invenção dessa tradição também contou com o apoio decisivo dos euclidianos do Rio de Janeiro, que participaram das comemorações e das conferências na cidade, fizeram articulações para conseguir do governo federal o tombamento da cabana citada acima e apelidaram a cidade de São Paulo de “Meca do Euclidianismo." Todas essas atividades, realizadas incessantemente durante várias décadas transformaram, de fato, a cidade de São José do Rio Pardo em um grande ponto de referência no assunto Euclides da Cunha. Algumas afirmações de Regina Abreu reiteram o que foi exposto acima: “A terra santa de Euclides da Cunha foi sendo esculpida aos poucos.” 327

O Grêmio Euclides da Cunha, criado no Rio de Janeiro, encontrava apoio decisivo em São Paulo. São José do Rio Pardo transformava-se no centro sagrado irradiador do culto a Euclides da Cunha. Como assinalou Almeida Magalhães, de um casebre de zinco, os riopardenses 'fizeram uma igreja. Santificaram o local e mais tarde protegeram o casebre com uma moderna construção que é quase uma redoma de cristal. Deram o nome do escritor a um dos bairros mais famosos da cidade. Colégios e até associações desportivas ostentam nas suas insígnias o apelido glorioso. ${ }^{328}$

E mais adiante:

Imortalizando a cabana, retinha-se seu fluxo sagrado. A cabana era uma relíquia da divina força poética que se manifestou no escritor. A redoma de vidro seria, então, capaz de imortalizar a cabana que imortalizou o escritor que produziu a obra imortal, pois para que existem redomas, senão para proteger as relíquias ou as imagens dos santos e das divindades? ${ }^{329}$

Portanto, e mais uma vez utilizando com abundância termos religiosos, Abreu reitera o compromisso dos euclidianos com a imortalização do escritor, considerado quase heróico pela grandeza de sua obra. Contribuiu de maneira substancial para essa imortalização do escritor a conservação de todo vestígio que pudesse, de alguma maneira, estabelecer uma ligação entre Euclides da Cunha e a cidade de São José do Rio Pardo. A militância incansável dos

\footnotetext{
${ }^{327}$ ABREU, Regina. O enigma de Os Sertões. Rio de Janeiro, Rocco, 1988, p.314.

${ }^{328}$ Idem Ibidem, p. 317.
} 
integrantes dos dois grêmios, e o compromisso dos mesmos com a conservação da obra do escritor e com a consolidação de seu nome entre os maiores da nação foram fundamentais para construir essa tradição, em que o nome de Euclides da Cunha aparece intimamente ligado à cidade de São José do Rio Pardo.

Esse trabalho incessante, de cultivo e conservação da memória de Euclides da Cunha, iniciado no Rio de Janeiro e continuado na cidade de São José do Rio Pardo, também contribuiu de maneira substancial para consolidar o nome de Euclides entre os maiores escritores da nação, posto que Euclides da Cunha ocupa, sem dúvida, até os dias atuais.

${ }^{329}$ Idem Ibidem, p. 319. 


\section{CONCLUSÃO}

A maior preocupação deste trabalho não foi a de definir, exatamente, em que teoria científica Euclides da Cunha teria melhor se enquadrado, até porque um exercício classificatório dessa natureza não nos levaria muito longe. O que se pretendeu nessa dissertação foi apontar a participação de um grupo de intelectuais brasileiros na criação do Grêmio Euclides da Cunha do Rio de Janeiro, e no fortalecimento do Grêmio de São José do Rio Pardo e, mais do que isso, na divulgação da obra do escritor Euclides da Cunha. A pesquisa procurou mostrar como o engajamento desses intelectuais, entre os quais se destacavam Venâncio Filho, Sussekind de Mendonça e Roquette-Pinto, contribuiu para a construção de uma memória que, ainda hoje, associa Euclides ao positivismo e que o coloca no panteão dos maiores escritores da nação, como aquele que teria defendido e denunciado as atrocidades cometidas contra o sertanejo na guerra de Canudos, mas sobretudo como aquele que havia utilizado o conhecimento científico para erigir um grande monumento literário. Uma das conclusões deste trabalho é a de que a construção dessa memória não se deu apenas pela afirmação explícita de que Euclides foi positivista, mas também pela criação de rituais de adoração ao escritor semelhantes ao da Religião da Humanidade, pelo realce de sua identidade com o conhecimento científico e pelo pouco destaque dado à utilização de conceitos evolucionistas na obra de Euclides. Esse pouco destaque dado à identidade entre Euclides e o evolucionismo pode ter sido resultado, também, da posição ideológica dos mesmos, que além de demonstrarem simpatia em relação à filosofia de Comte, eram contrários ao chamado racismo científico, como assinalou Regina Abreu. Esse trabalho de esquecimento que, ao que parece, iniciou-se já na década de 30 pode ter contribuído para que a associação entre Euclides da Cunha e o evolucionismo fosse, de fato, esquecida em benefício de outra, que o associava ao positivismo.

Além disso, esse trabalho levantou e pretendeu trabalhar a hipótese de que o esforço dos euclidianos estudados estava relacionado a um projeto de valorização do conhecimento científico, no caso, da literatura científica, que tinha em Euclides da Cunha o seu maior representante e que buscava, além de situá-lo no posto de maior escritor nacional, tornar a literatura de cunho científico mais valorizada do que a literatura ficcional, vista como menos preocupada com a descrição objetiva da realidade, vertente cujo nome de maior peso era Machado de Assis. A leitura de artigos, livros e conferências dadas pelos euclidianos citados 
nos levam a crer que era a imagem de um Euclides da Cunha homem de ciência que eles desejavam ressaltar e que, para eles, era exatamente por essa postura científica que Euclides da Cunha merecia figurar entre os maiores, senão o maior, escritor da nação. Ainda que os mesmos euclidianos também tivessem escrito e comentado inúmeras outras qualidades da obra do escritor. A defesa desse tipo específico de literatura, em contraposição à ficcional, teria gerado a discussão nos meios acadêmicos, em que Machado de Assis e Euclides da Cunha eram colocados como representantes de modelos literários opostos. Embora a questão nem sempre tenha sido colocada nestes termos pelos críticos literários da época, as constantes comparações entre os dois escritores, que aparecem em mais de um crítico literário desse período, permitem que se lance a hipótese de que havia, de fato, divergências entre estes críticos a respeito de quem seria o maior escritor nacional. Mais do que saber quem ganhou a batalha, Euclides ou Machado, importa a este trabalho ressaltar que, ao menos, a posição de maior escritor brasileiro de Machado de Assis começou a ser questionada por alguns críticos da época, o que pode ser entendido como um possível sucesso dos militantes dos grêmios euclidianos, que tanto batalharam e insistiram na idéia de que Euclides foi o maior escritor brasileiro.

Considero que essa valorização da postura científica de Euclides pode estar relacionada à própria formação acadêmica dos euclidianos: apesar não terem exercido a profissão durante a maior parte de suas vidas, Roquette-Pinto e Venâncio Filho haviam se formado em medicina e engenharia, respectivamente, o que lhes conferia uma formação científica. Venâncio Filho foi professor de Física e esteve envolvido em inúmeros projetos de valorização e divulgação do conhecimento científico. Roquette-Pinto foi, ainda, diretor do Museu Nacional, uma das principais instituições de produção e divulgação da ciência na época.

Outra idéia importante presente neste trabalho está relacionada, mais especificamente, ao Grêmio Euclides da Cunha: a forma como Euclides era reverenciado no Grêmio e até mesmo o culto à personalidade, que são características da instituição do Rio de Janeiro e também de São José do Rio Pardo, se assemelham bastante às da igreja positivista o que, dada a formação intelectual e ideológica de seus dirigentes cariocas, indica sua proximidade com essa corrente filosófica. 
Por todos esses motivos, foi escolhido como título dessa dissertação "A militância em torno da glorificação de Euclides da Cunha: um projeto político-ideológico.” Projeto político porque estava integrado a uma valorização dos saberes científicos, entre eles a literatura de cunho científico, e do próprio positivismo, que começava a entrar em declínio na década de 30. E projeto ideológico porque refletia a visão de mundo destes intelectuais. Para eles, a literatura científica de Euclides era uma raridade, no caso brasileiro, que deveria ser lembrada, divulgada, reverenciada, elogiada. Euclides da Cunha não era, para os dirigentes do Grêmio a ele dedicado, apenas um escritor brasileiro. Era o escritor brasileiro por antonomásia e, como tal, deveria ser reconhecido por todos os brasileiros. Foi para isso que trabalharam incansavelmente os principais personagens desse trabalho, Roquette-Pinto, Sussekind de Mendonça e Venâncio Filho. 


\section{FONTES}

\subsection{Academia Brasileira de Letras}

Arquivo Euclides da Cunha. Série 7. Código de referência: BR ABL AA EC gec.

Boletim da Associação Brasileira de Amigos de Auguste Comte. Abril de 1947

Discurso de posse de Euclides da Cunha na Academia Brasileira de Letras, in: Revista da Academia Brazileira de letras. Rio de Janeiro, abril de 1911.

Por Protesto e Adoração: In memorian de Euclides da Cunha. 1909-1919. Edição do Grêmio Euclides da Cunha.

Revista do Grêmio Euclides da Cunha. Rio de Janeiro. Nos anos de 1919, 1926, 1935, 1936, 1937, 1938, 1939.

CARNEIRO, Paulo e LINS, Ivan. Discursos na Academia Brasileira de Letras. Rio de Janeiro, 1971.

ROQUETTE-PINTO, Edgard e MENDONÇA, Edgard Sussekind de. Ensaios sobre Os Sertões. Discurso na ABL em sessão comemorativa do $20^{\circ}$ aniversário da morte de Euclides da Cunha. Revista da Academia Brasileira de Letras 1929.

\subsection{Biblioteca Nacional}

Ata de fundação da Associação Brasileira de Amigos de Auguste Comte. 05/07/1945. 


\subsection{Museu Nacional}

Revista do Museu Nacional. Rio de Janeiro. 1944-1945.

\subsection{Outras Fontes}

BARRETO, Paulo (JOÃO DO RIO) A Igreja Positivista. Disponível em: http://pt.wikisource.org/wiki/A_Igreja_Positivista. Acesso em Agosto/2009.

Casa de Cultura Euclides da Cunha. Disponível em: http://www.casaeuclidiana.org.br/texto/ler.asp?Id=1243\&Secao=111. Acesso em Dezembro/2009.

CUNHA, Euclides da; GALVÃO, Walnice Nogueira; GALOTTI, Oswaldo Correspondência de Euclides da Cunha: ativa. São Paulo: EDUSP, 1997. Os autores citados reeditaram as correspondências de Euclides da Cunha, que já tinham sido publicadas por Francisco Venâncio Filho.

CUNHA, Euclides da; GALVÃo, Walnice Nogueira. Os Sertões. Ed. critica. - São Paulo. Brasiliense, 1985.

Contrastes e confrontos/ Nativismo Provisório. Disponível em: http://pt.wikisource.org/wiki/Contrastes_e_Confrontos/Nativismo_provis\%C3\%B3rio. Acesso em Agosto/2009.

Contrastes e confrontos/ O marechal de Ferro. Disponível em: http://pt.wikisource.org/wiki/Contrastes_e_Confrontos/II-O_Marechal_de_ferro. Acesso em Agosto/2009. 
Contrastes e confrontos/civilização. Disponível em: http://pt.wikisource.org/wiki/Contrastes_e_Confrontos/Civiliza\%C3\%A7\%C3\%A3o. Acesso em Agosto/2009.

Artigo de Euclides da Cunha de 19 de março de 1982. Disponível em: http://pt.wikisource.org/wiki/Artigo_de_Euclides_da_Cunha_de_19_de_mar\%C3\%A7o_de_1 892. Acesso em Agosto/ 2009.

A Nossa Vendéia. Disponível em: http://pt.wikisource.org/wiki/A_nossa_vend\%C3\%A9ia_(1). Acesso em Agosto 2009.

Discurso de Posse de Moisés Gicovate (também euclidiano) no IHG-SP. São Paulo, 1982.

ROQUETTE-PINTO, Edgard. “Os Sertões”. Boletim de Ariel. Rio de Janeiro, setembro de 1933.

Euclides da cunha naturalista in: Seixos rolados: Estudos brasileiros. São Paulo, Ed. Nacional, 1927.

Francisco Venâncio Filho: Um Educador Brasileiro. Rio de Janeiro, ABL, 1984.

Francisco Venâncio Filho: Um Educador Brasileiro. Rio de Janeiro, Nova Fronteira, 1995.

ROMERO, Silvio. Doutrina contra Doutrina. O evolucionismo e o positivismo na república do Brasil.Rio de Janeiro. Editor J.B Nunes.1894.

Ensaios de sociologia e literatura. Rio de Janeiro: H. Garnier, 1901.

História da literatura brasileira. 2. ed. Rio de Janeiro: H. Garnier, 1902-

1903. 
SPENCER, Herbert. Introduction a la science sociale. Ed. Paris: F. Alcan, 1908.

VENÂNCIO FILHO, Francisco. A gloria de Euclydes da Cunha. São Paulo, Ed. Nacional, 1940.

Euclydes da Cunha a seus amigos. São Paulo, Ed. Nacional, 1938.

Euclides da Cunha: ensaio biobibliográfico. Rio de Janeiro, Tipografia Nacional, 1931.

Euclides da Cunha: Retrato humano. Rio de Janeiro, Tipografia Industrial, 1931.

Euclides da Cunha e a Amazônia. Revista Brasileira, Rio de Janeiro, ano3, n.7, set 1943.

Euclides da Cunha e o Rio-Branco. Revista Brasileira, Rio de Janeiro, ano 3, n.5, mar 1943.

Joaquim Gomes de Souza. Revista Brasileira, Rio de Janeiro, ano 3, n.5, mar 1943

Atualidade de Euclides da Cunha. Revista Brasileira, Rio de Janeiro, ano4, n.9, abril 1944.

Os Sertões. Revista Brasileira, Rio de Janeiro, ano4, n.11, out 1944.

Fundamentos Científicos de Os Sertões. Revista Brasileira, Rio de Janeiro, ano 5, n.9, dez 1945 


\section{BIBLIOGRAFIA}

ABREU, Regina. O enigma de Os Sertões. Rio de Janeiro, Rocco, 1988.

ALONSO, Ângela. Reforma, Ordem e Progresso. Nossa História, Rio de Janeiro, ano3, n.27, jan 2006.

Idéias em movimento. A geração de 1870 na crise do Brasil império. São

Paulo, paz e terra, 2002.

Raízes positivistas do reformismo dos anos 1930: o caso Paulo Carneiro.

In MAIO, Marcos Chor. Ciência, Política e Relações Internacionais. Ensaios sobre Paulo Carneiro. Rio de Janeiro, editora Fiocruz, 2004.

ARON, Raymond. Auguste Comte. In, As Etapas do pensamento sociológico. São Paulo, Martins Fontes, 2002.

BARBOSA, Francisco de Assis. A Vida de Lima Barreto. Rio de Janeiro: José Olympio Editora, 2003.

CANDIDO, Antonio. O método crítico de Silvio Romero. São Paulo: Ed. da Universidade de São Paulo, 1988.

CARVALHO, José Murilo de. A formação das almas: o imaginário da República no Brasil. Companhia das Letras, São Paulo 1990.

CAVAZOTTI, Maria Auxiliadora. O projeto republicano de educação nacional na versão de José Veríssimo. São Paulo; Annablume, 2003.

CHALHOUB, Sidney. Machado de Assis, historiador. São Paulo: Companhia das Letras, 2003. 
CIVITA, Victor (Edit.). Os pensadores: Auguste Comte. $2^{\mathrm{a}}$ ed. São Paulo: ABRIL

CULTURAL, 1983.

CORDEIRO, Rogério. Ciência e Literatura: Pressupostos do pensamento formal de Euclides da Cunha, in XIV Simpósio Estadual de História, UFJF, 2004.

COSTA, João Cruz. Contribuição à história das idéias no Brasil. Rio de Janeiro, Civilização Brasileira, 1967.

O positivismo na República notas sobre a história do positivismo no Brasil.

São Paulo, Ed Nacional, 1956.

Contribuição a história das idéias no Brasil: o desenvolvimento da filosofia no Brasil e a evolução histórica nacional. Rio de Janeiro. J. Olympio, 1956.

DARWIN, Charles. A Origem das Espécies. São Paulo, Hemus, 1981.

FREYRE, Gilberto. Atualidade de Euclides da Cunha. Rio de janeiro, casa do estudante do Brasil, 1943.

Perfil de Euclides e outros perfis. Rio de Janeiro, José Olympio, 1944.

Ordem e progresso, $3^{\mathrm{a}}$ ed., Liv. Rio de Janeiro, J. Olympio Ed., 1974.

FURLANI, Geraldo Majella. O Homem e a luta: traços geográficos. Gazeta do Rio Pardo, 8 de agosto de 1982. Suplemento V.

GAGNEBIN, Jeanne Marie. Lembrar escrever esquecer. São Paulo: Editora 34, 2006.

GASTALDI, Santiago. Fundamentos Biológicos em Os Sertões. Tapejara, Ponta Grossa, dezembro 1950.

GICOVATE, Moisés. Atualidade e permanência de Os Sertões. Revista paulistana de medicina, São Paulo, v.97. Abril/junho 1981. Suplemento cultural número 8. 
Euclides da Cunha e o instituto histórico e geográfico de são Paulo.

Gazeta do Rio Pardo, São José do Rio Pardo, 8 de agosto de 1982. Suplemento euclidiano V.

HOBSBAWM, Eric; RANGER, Terence O. A Invenção das tradições. Rio de Janeiro: Paz e Terra, 1984.

ISKANDAR, Jamil Ibrahim e LEAL, Maria Rute. Sobre positivismo e educação. In: Revista Diálogo Educacional, Curitiba, v. 3, n.7, p. 89-94, set./dez. 2002.

JUNIOR, João Ribeiro. O que é Positivismo? São Paulo, Brasiliense, 2003.

LIMA, Luiz Costa. Euclides da Cunha: Contrastes e confrontos do Brasil. Rio de janeiro: Contraponto: NUSEG, 2000.

Terra Ignota: A construção de Os Sertões. Rio de Janeiro: Civilização

Brasileira, 1997.

LINS, Ivan Monteiro de Barros. História do Positivismo no Brasil. São Paulo, Ed Nacional, 1967.

LOVISOLO, Hugo. O Positivismo na Argentina e no Brasil. In: Revista Brasileira de Ciências Sociais. Disponível em: http://www.anpocs.org.br/portal/content/view/123/54/. Acesso em Agosto/2009.

MAIO, Marcos Chor. Ciência, Política e Relações Internacionais. Ensaios sobre Paulo Carneiro. Rio de Janeiro: editora Fiocruz, 2004.

NEVES, Cynthia Agra de Brito. Positivismo e vida militar em Alberto Rangel. 1995. Monografia (graduação). Curso de graduação em Licenciatura em Letras. Universidade Estadual de Campinas, UNICAMP, Brasil.

NEVES, Margarida de Souza; HEIZER, Alda; RODRIGUES, Marly. A ordem e o progresso: o Brasil de 1870 a 1910. 6ª ed. - São Paulo: Atual, 1995. 
NOFUENTES, Vanessa Carvalho. PONTIFÍCIA UNIVERSIDADE CATÓLICA DO RIO

DE JANEIRO Departamento de História. . Um desafio do tamanho da nação: a campanha da Liga Brasileira Contra o Analfabetismo (1915-1922). 2008. 163 f. Dissertação (Mestrado em História). Pontifícia Universidade Católica do Rio de Janeiro, Rio de Janeiro, 2008.

OLIVEIRA FILHO, Benjamin de. A filosofia social de Augusto Comte. -. Rio de Janeiro: Haddad, 1954.

OLIVEIRA, Lelita. Sociologia Comteana. São Paulo, FAPESP, 1999.

ORTIZ, Renato. Cultura brasileira e identidade nacional. 3a ed. - São Paulo: Brasiliense.

PONTES, Eloy. A vida dramática de Euclides da Cunha. Rio de Janeiro, José Olympio, 1938.

REALE, Miguel. Face Oculta de Euclides da Cunha. Rio de Janeiro, Topbooks, 1993.

SANTANA, José Carlos Barreto de. Ciência e Arte: Euclides da Cunha e as Ciências Naturais. São Paulo, Hucitec, 1999.

SEVCENKO, Nicolau O prelúdio republicano, astúcias da ordem e ilusões do progresso in: NOVAIS, Fernando A. História da vida privada no Brasil. São Paulo: Companhia das Letras, 1997- $4 \mathrm{v}$.

SOUZA FILHO, Danilo Marcondes de. Iniciação à história da filosofia: dos pré-socráticos a Wittgenstein. 8. Ed. Rio de Janeiro: J. Zahar, 2004.

SOUZA, Natália Peixoto Bravo e GALVÃO, Gastão. O estigma de uma obra: Euclides da Cunha e suas reapropriações sob o ponto de vista do positivismo e do evolucionismo. . In Revista da Sociedade Brasileira de História da Ciência, 2007, Rio de Janeiro.

SOUZA, Vanderlei Sebastião de. A Eugenia no Brasil: Ciência e pensamento social no movimento eugenista brasileiro no entre - guerras. Disponível em: 
http://www.anpuh.uepg.br/xxiiisimposio/anais/textos/Vanderlei\%20Sebasti\%C3\%A3o\%20de \%20Souza.pdf.

SUCUPIRA, Newton Lins Buarque. Francisco Venâncio Filho. In: FÁVERO, Maria de Lourdes de Albuquerque; BRITTO, Jader de Medeiros. . Dicionário de educadores no Brasil: da colônia aos dias atuais. Rio de Janeiro: UFRJ/ MEC-Inep, 1999.

VELA, Fernando. Abreviatura de Principios de Sociologia de H. Spencer. Buenos Aires: Revista de Occidente Argentina, 1947.

VELHO, Gilberto. Memória, Identidade e Projeto. In: Projeto e metamorfose: Antropologia das sociedades complexas. 2a ed. Rio de Janeiro: J. Zahar 1999.

VELLOSO, Mônica Pimenta. A literatura como espelho da nação. Estudos Históricos, Rio de Janeiro, vol.1, n.2, 1988.

O Modernismo e a Questão Nacional, in: FERREIRA, Jorge e

DELGADO, Lucília de Almeida Neves (org.). O Brasil Republicano. Rio de Janeiro, Civilização Brasileira, 2003.

VENÂNCIO FILHO, Alberto. O Movimento Euclidianista, In: Ciclo Comemorativo da Publicação de Os Sertões, 2002, Rio de Janeiro, RJ. Disponível em: www.abl.org.br. Acesso em outubro de 2004.

Edgar Roquette-Pinto. In: FÁVERO, Maria de Lourdes de Albuquerque; BRITTO, Jader de Medeiros. . Dicionário de educadores no Brasil: da colônia aos dias atuais. Rio de Janeiro: UFRJ/ MEC-Inep, 1999.

VERÍSSIMO, José. Historia da literatura brasileira: de Bento Teixeira (1601) a Machado de Assis (1908). Rio de Janeiro: Liv. Francisco Alves, 1916.

VENTURA, Roberto. Euclides da Cunha: Esboço Biográfico. São Paulo, Cia das Letras, 2003. 
Estilo Tropical. História cultural e polêmicas literárias no Brasil. São Paulo: Cia das Letras, 1991.

VIDAL, Diana Gomes. Edgard Sussekind de Mendonça. In: FÁVERO, Maria de Lourdes de Albuquerque; BRITTO, Jader de Medeiros. . Dicionário de educadores no Brasil: da colônia aos dias atuais. Rio de Janeiro: UFRJ/ MEC-Inep, 1999. 


\section{ENTREVISTA}

Entrevista a Alberto Venâncio Filho feita por mim. Rio de Janeiro, 2007. 